\title{
Differences in groupings of students' academic achievement, attendance and attitude as they move from a traditional to a modified 4 x 4 block schedule
}

Charles Theodore Keenan

West Virginia University

Follow this and additional works at: https://researchrepository.wvu.edu/etd

\section{Recommended Citation}

Keenan, Charles Theodore, "Differences in groupings of students' academic achievement, attendance and attitude as they move from a traditional to a modified 4 x 4 block schedule" (2000). Graduate Theses, Dissertations, and Problem Reports. 2320.

https://researchrepository.wvu.edu/etd/2320

This Dissertation is protected by copyright and/or related rights. It has been brought to you by the The Research Repository @ WVU with permission from the rights-holder(s). You are free to use this Dissertation in any way that is permitted by the copyright and related rights legislation that applies to your use. For other uses you must obtain permission from the rights-holder(s) directly, unless additional rights are indicated by a Creative Commons license in the record and/ or on the work itself. This Dissertation has been accepted for inclusion in WVU Graduate Theses, Dissertations, and Problem Reports collection by an authorized administrator of The Research Repository @ WVU.

For more information, please contact researchrepository@mail.wvu.edu. 
DIFFERENCES IN GROUPINGS OF STUDENTS' ACADEMIC ACHIEVEMENT, ATTENDANCE AND ATTITUDE AS THEY MOVE FROM A TRADITIONAL TO A MODIFIED 4 X 4 BLOCK SCHEDULE

by

Charles T. Keenan

\section{DISSERTATION}

Submitted to the College of Human Resources and Education at West Virginia University

In Partial Fulfillment of the Requirements for the Degree of Doctor of Education

Phyullis Durden, Ed.D., Committee Chair

Ernest Goeres, Ed.D.

David McCrory, Ed.D.

Charles Joyce, Ed.D.

R. Lynn Canady, Ed.D.

Department of Educational Leadership

Morgantown, West Virginia

2000

(C) 2000 Charles T. Keenan 


\section{ABSTRACT \\ DIFFERENCES IN GROUPINGS OF STUDENTS' ACADEMIC ACHIEVEMENT, ATTENDANCE, AND ATTITUDE AS THEY MOVE FROM A TRADITIONAL TO A MODIFIED 4 X 4 BLOCK SCHEDULE}

\section{CHARLES T. KEENAN}

The purpose of this investigation is to identify the differences in groups of high school students' achievement, attendance, and attitude as they move from a traditional schedule to a modified $4 \times 4$ block schedule. The population for this study consisted of all 10th, 11th, and 12th grade students at a high school during the 1998-1999 school year. There were four samples taken from this population, the first, second, third, and fourth quartiles of students. A survey questionnaire was used to determine student attitude. This survey was distributed to all 10th, 11 th, and 12th grade students at the high school who participated in this study. Respondents were assured that their participation was voluntary and confidentiality and anonymity was maintained. Student attendance and grades were determined through official school records. The subjects for this study were those who had completed a student assent form and turned in a parental consent form. There was the potential to have over 500 subjects for this study. There is approximately a 30 percent minority population at the high school, and the gender distribution is equally balanced. No minority or gender grouping or exclusion was considered for this study. Student achievement, based on a comparison of grade point average from the 1997-1998 school year to the 19981999 school year, indicated a mean growth over the two year period of 0.05 . The student body, as a whole, had a mean reduction in absenteeism over the two year period of 4.62 days. As a whole, the students' attitude toward the change to the modified $4 \times 4$ block scheduling was positive. Of the 23 indicators measured, 19 showed a more favorable response toward the change to the modified $4 \times 4$ block schedule. A significant result of the study is the impact the change from the traditional schedule to the modified $4 \times 4$ block schedule had on those students grouped in Quartile 2 (26-50\%) and students grouped in Quartile 3 (51$75 \%$ ). The results of the study indicate that moving from the traditional schedule to a modified $4 \times 4$ block schedule has a positive impact on achievement, attendance, and attitude of students. 


\section{ACKNOWLEDGMENTS}

This dissertation is dedicated to Drs. Dan and Dianne Keenan, who have made this dream a reality through their guidance, love and support. 
TABLE OF CONTENTS

Page No.

\section{CHAPTER ONE}

$\begin{array}{ll}\text { Introduction and Background } & 1\end{array}$

Statement of the Problem 5

$\begin{array}{ll}\text { Justification/Need for the Study } & 6\end{array}$

$\begin{array}{ll}\text { Definition of Terms } & 7\end{array}$

$\begin{array}{ll}\text { Organizational Change } & 7\end{array}$

$\begin{array}{ll}\text { Traditional Schedule } & 7\end{array}$

$\begin{array}{lr}\text { Block Scheduling } & 8\end{array}$

Four by Four Block Scheduling $\quad 8$

$\begin{array}{lr}\text { Academic Achievement } & 8\end{array}$

$\begin{array}{ll}\text { Grouping of Students } & 8\end{array}$

$\begin{array}{ll}\text { Limitations } & 8\end{array}$

$\begin{array}{ll}\text { Summary } & 10\end{array}$

$\begin{array}{ll}\text { CHAPTER TWO } & 11\end{array}$

$\begin{array}{ll}\text { Review of Literature } & 11\end{array}$

$\begin{array}{ll}\text { Overview } & 11\end{array}$

$\begin{array}{ll}\text { Organizational Change } & 11\end{array}$

History of High School Scheduling 13

$\begin{array}{ll}\text { Block Scheduling } & 17\end{array}$

Impact on Instructional Strategies $\quad 22$ 
Page No.

Benefits of Block Scheduling $\quad 27$

Inhibitors of Block Scheduling $\quad 29$

The Importance of Block Scheduline on Academic

$\begin{array}{ll}\text { Achievement } & 30\end{array}$

Impact on Students 32

Groupings and The Block 33

$\begin{array}{ll}\text { Summary } & 36\end{array}$

$\begin{array}{ll}\text { CHAPTER THREE } & 38\end{array}$

Research Methods and Procedures 38

$\begin{array}{ll}\text { Demographics } & 38\end{array}$

$\begin{array}{ll}\text { Participants } & 39\end{array}$

$\begin{array}{ll}\text { Design } & 39\end{array}$

$\begin{array}{ll}\text { Data } & 42\end{array}$

$\begin{array}{ll}\text { Instrument } & 43\end{array}$

$\begin{array}{ll}\text { Procedure } & 43\end{array}$

Analysis of Data $\quad 45$

$\begin{array}{ll}\text { CHAPTER FOUR } & 48\end{array}$

$\begin{array}{ll}\text { Analysis and Results } & 48\end{array}$

Overview of the Study 48

$\begin{array}{ll}\text { Student Achievement } & 49\end{array}$

Student Attendance 53 
Page No.

$\begin{array}{ll}\text { Student Attitude } & 57\end{array}$

$\begin{array}{ll}\text { Summary } & 93\end{array}$

$\begin{array}{ll}\text { CHAPTER FIVE } & 96\end{array}$

Summary, Conclusions, and Recommendations 96

$\begin{array}{ll}\text { Purpose of the Study } & 96\end{array}$

Summary of Procedures 96

$\begin{array}{ll}\text { Student Achievement } & 97\end{array}$

$\begin{array}{ll}\text { Student Attendance } & 99\end{array}$

$\begin{array}{ll}\text { Student Attitude } & 100\end{array}$

$\begin{array}{ll}\text { Considerations } & 103\end{array}$

$\begin{array}{ll}\text { Conclusions } & 105\end{array}$

$\begin{array}{ll}\text { Implications for the Profession } & 107\end{array}$

$\begin{array}{ll}\text { Recommendations } & 107\end{array}$

$\begin{array}{ll}\text { WORKS CITED } & 109\end{array}$

$\begin{array}{ll}\text { APPENDICES } & 119\end{array}$

$\begin{array}{lll}\text { APPENDIX A Block Scheduling Student Survey } & 120\end{array}$

APPENDIX B Approval Letter from Superintendent 124

APPENDIX C Approval Form from Human Subjects

Review Committee 126

$\begin{array}{lll}\text { APPENDIX D } & \text { Consent Form }\end{array}$

$\begin{array}{lll}\text { APPENDIX E } & \text { Assent Form } & 128\end{array}$ 
Page No.

APPENDIX F Comments on Question 26 129

APPENDIX G Individual Quartile, Total and Aggregate 130

Percentage of Responses to Questions

Three Through Twenty-Five 


\section{LIST OF EXAMPLES}

Page No.

\section{CHAPTER TWO}

$\begin{array}{lll}\text { Example } 1 & \text { Yearly Traditional Class Schedule } & 19\end{array}$

Example 2 Traditional Weekly Class Schedule 19

Example 3 Yearly A/B Block Class Schedule 20

Example 4 Weekly A/B Block Class Schedule 20

Example 5 Yearly 4 x 4 Block Class Schedule 21

Example 6 Weekly 4 x 4 Block Class Schedule 21

Example 7 Yearly Modified 4 x 4 Block Class Schedule 21

Example 8 Weekly Modified 4 x 4 Block Class Schedule 22 


\section{LIST OF FIGURES}

Page No.

\section{CHAPTER TWO}

Figure 1 Percentile Gains on 11th Grade Norm-Referenced Test 1996-1997, By Type of Schedule

CHAPTER THREE

Figure $1 \quad$ Population Sample (Sophomores 1998-1999) 40

Figure 2 Population Sample (Juniors 1998-1999) 41

Figure 3 Population Sample (Seniors 1998-1999) 42

Figure 4 Population Sample (Aggregate 1998-1999) 42

Figure $5 \quad$ Rate of Return (1998-1999) 44 
LIST OF TABLES and CHART

Page No.

\section{CHAPTER FOUR}

Table 1 Mean Grade Point Average By Quartile Within Each

Grade Level For The 1997-1998 School Year

49

Table 2 Mean Grade Point Average By Quartile Within Each

Grade Level For The 1998-1999 School Year

50

Table 3 Mean Grade Point Average Score Difference By

Quartile From the 1997-1998 School Year To The 1998-1999 School Year

50

Table 4 Percentage of Students Within Each Quartile Who Had Improved Their Grade Point Average From The 19971998 School Year to the 1998-1999 School Year

Table 5 Mean Number of Student Absences By Quartile Within Each Grade Level For the 1997-1998 School Year

Table 6 Mean Number of Student Absences By Quartile Within Each Grade Level For the 1998-1999 School Year

Table 7 Mean Student Absence Improvement By Quartile From The 1997-1998 School Year To The 1998-1999 School Year 
Page No.

Table 8 Percentage of Students Within Each Quartile Who Had Improved Their Attendance From The 1997-1998 School Year To The 1998-1999 School Year 56

Table 9 Summary of Student Responses By Quartile And As A Whole To Question 1 Of The Attitude Questionnaire 58

Table 10 Summary of Student Responses By Quartile And As A Whole To Question 2 Of The Attitude Questionnaire 59

Table 11 Summary of Student Responses By Quartile And As A Whole To Question 3 Of The Attitude Questionnaire 60

Table 12 Summary of Student Responses By Quartile And As A Whole To Question 4 Of The Attitude Questionnaire

Table 13 Summary of Student Responses By Quartile And As A Whole To Question 5 Of The Attitude Questionnaire

Table 14 Summary of Student Responses By Quartile And As A Whole To Question 6 Of The Attitude Questionnaire 64

Table 15 Summary of Student Responses By Quartile And As A Whole To Question 7 Of the Attitude Questionnaire 65

Table 16 Summary of Student Responses By Quartile And As A Whole To Question 8 Of The Attitude Questionnaire 67 Table 17 Summary of Student Responses By Quartile And As A Whole To Question 9 Of The Attitude Questionnaire 
Page No.

Table 18 Summary of Student Responses By Quartile And As A Whole To Question 10 Of The Attitude Questionnaire

Table 19 Summary of Student Responses By Quartile And As A Whole To Question 11 Of The Attitude Questionnaire

Table 20 Summary of Student Responses By Quartile And As A Whole To Question 12 Of The Attitude Questionnaire

Table 21 Summary of Student Responses By Quartile And As A Whole To Question 13 Of The Attitude Questionnaire

Table 22 Summary of Student Responses By Quartile And As A Whole To Question 14 Of The Attitude Questionnaire

Table 23 Summary of Student Responses By Quartile And As A Whole To Question 15 Of The Attitude Questionnaire

Table 24 Summary of Student Responses By Quartile And As A Whole To Question 16 Of the Attitude Questionnaire

Table 25 Summary of Student Responses By Quartile And As A Whole To Question 17 Of The Attitude Questionnaire

Table 26 Summary of Student Responses By Quartile And As A Whole To Question 18 Of The Attitude Questionnaire

Table 27 Summary of Student Responses By Quartile And As A Whole To Question 19 Of The Attitude Questionnaire

Table 28 Summary of Student Responses By Quartile And As A 
Page No.

Whole To Question 20 Of The Attitude Questionnaire

85

Table 29 Summary of Student Responses By Quartile And As A

Whole To Question 21 Of The Attitude Questionnaire

86

Table 30 Summary of Student Responses By Quartile And As A

Whole To Question 22 Of The Attitude Questionnaire

Table 31 Summary of Student Responses By Quartile And As A

Whole To Question 23 Of The Attitude Questionnaire $\quad 90$

Table 32 Summary of Student Responses By Quartile And As A

Whole To Question 24 Of The Attitude Questionnaire

Table 33 Summary of Student Responses By Quartile And As A

Whole To Question 25 Of The Attitude Questionnaire

Chart 1 Aggregated Grade Point And Attendance Improvement

From 1997-1998 School Year to 1998-1999 School

Year 


\section{CHAPTER ONE}

Introduction and Background

The issue of school reform and change in education is as prevalent today as ever. There are over 200 school reform models across the United States from which schools can choose to help set new directions within their organizations. The issue of school reform is so prevalent that the federal government and all fifty state governments are allocating millions of dollars to schools and school districts to see change and restructuring occur. The topics of change range from curriculum, instruction, and evaluation to the reconstruction of the school day and school year.

Change is a difficult process. In order for change to be successful, the change agent must have a clear understanding of organizational change theory. Many great leaders have made poor choices about restructuring because they had not learned how to use multiple lenses to get a better reading of what they were up against and what they might do about it (Bolman \& Deal, 1997). Initiating successful change is not a simple process, and there are many factors that must be considered when restructuring.

According to Bolman and Deal (1997), there are four main "frames" through which a manager must view in order to take into consideration the important factors in restructuring an organization -- structural, human, political, and symbolic. The structural frame deals with what the change process will do to the organization as far as the overall system is concerned. The human resource frame considers people and organizations as well as interpersonal and group dynamics. The political frame entails power, conflict, and coalitions, as well as the politics surrounding and involving the organization. The symbolic frame views the organization in terms of rituals and culture within or created by the organization. Bolman and Deal (1997) feel that, in order to ensure an effective restructuring process, the organizational leader must take into consideration all four of these "frames" and integrate the ideas behind them. 
There are several stages that people within an organization go through when facing a change, with the length of time each individual spends in each phase differing greatly. There are four phases of change that need to be considered. The initial phase is denial, where there is shock or disbelief that the change is proposed. In the second phase, resistance, things seem to get worse for the individual and stress levels rise. After this period of struggle, people enter into the exploration stage, where alternatives and new possibilities are explored. Once the individual has broken through the exploration and discovered a new way of doing things the commitment stage has arrived (Anderson, 1993).

If an educator intends on making a positive change, it is important that he or she understands the theory behind change and the stages of change with which an organization must go through in the change process. This basically entails taking a proactive stance when dealing with the change. There are many different vantage points from which a keen educator must see the change in order to be prepared, and the stages of change must be given consideration prior to the process.

Changes can happen unannounced, and often do in the educational setting. But when an educator has advanced notice of potential change or can prepare for a change, it is crucial that the leader take the time to understand how the change will affect the organization. A proactive leader will prepare for a change and the situations that will occur from the change. It is, therefore, important to retrieve as much information regarding the change as possible, and placing the information into the proper perspective so that a well-thought-out decision can be made.

There are several educational leaders who have had a great deal of influence on educational reform in the late 1990s. One of the most prolific reform movement leaders is Dr. Ted Sizer (1996), professor at Brown University. Dr. Sizer (1996) has done extensive work on a national level with a goal to improve our educational system. 
Sizer (1996) has written a series of books known as the "Horace Trilogy." In the first book, Horace's Compromise (1984), Sizer (1996) shares his experiences and opinions as to what is wrong with the educational system in American High Schools. In the second book, Horace's School (1993), Sizer (1996) shares his ideas as to how to restructure American High Schools. Sizer (1996) developed what has come to be known as the "Ten Common Principles" of education. These principles are a list of ten ideas around which Sizer (1996) believes all schools should be centered. In the third book, Horace's Hope (1996), Sizer (1996) cites examples of success stories and practices which have helped improve schools based on his reform movement.

The basic idea behind Sizer's philosophy is that students need to be treated as human beings, not products. We must, as educators, provide for a more personalized education, helping students to use their minds well while mastering essential skills, knowledge, and attitude. This philosophy, along with the works of other educational leaders, has brought the topic of block scheduling to the forefront of change in school organizations in recent years.

Block Scheduling is basically rearranging the time structure of daily classroom instruction. The fundamental idea behind block scheduling is that longer periods of instructional time enable students to comprehend material better than in the traditional format and ultimately the learning process will be improved by the scheduling change. It is also argued that the students receive a more personalized education by having long periods of time with each instructor during the day. Students in block schedules also receive the benefit of a reduced daily course load. The end result is that students have fewer classes per day and more time to learn in each of the classes.

Block scheduling is not a panacea for all school problems; nor is it without challenges. Several pertinent questions have been raised regarding block scheduling and its practicality in schools. One concern is whether or not a student can pay attention to one teacher for 90 minutes. Another concern is the possible loss of 
classroom instructional time. Adversaries to block scheduling say that if a student misses one day of school, he or she is missing two days of work, and that a student will forget everything he or she has learned in a subject if there is a six month's lapse before the next sequential course. Proponents of block scheduling have logical answers as to how to prevent or solve all of these questions, and all of these answers lie in the way the whole organizational change regarding block scheduling is approached.

According to Robert Lynn Canady (1998), there are several positive contributions that block scheduling can bring to the school setting. Teachers and students both benefit from a more personalized education where there is less fragmentation of objectives being taught so material is more holistically understood. The block allows for teachers to prepare a variety of activities that could not have been done in a regular schedule because of time restrictions, giving everyone involved exposure to a variety of teaching and learning modes. The individualized attention which is enabled with block scheduling allows for earlier detection and intervention with student problems. There is also much research-based information supporting block scheduling that is listed in the review of literature section.

According to Rettig and Canady (1999), an important question that needs to be answered regarding block scheduling is "for whom in particular does this change to block scheduling create positive differences?" Many studies have shown the benefits of block scheduling for students as a whole and schools as organizations (Carroll, 1994; Canady and Rettig, 1995; Edwards, 1995; O'Neil, 1995). Educators involved in block scheduling have commented that it appears that the middle groupings of students have been affected the greatest by block scheduling (Canady, 1998). Research of this nature will be beneficial to educational leaders in determining if the change to block scheduling would be worthwhile to their institution. Educators will be able to see if block scheduling is a change from which their organization can truly benefit by understanding 
the differences for these groups of students associated with the change to block scheduling. It is not enough to say that block scheduling is a positive or negative change for all students if, in fact, the change to block scheduling creates different results for distinct groups of students.

With the many school reform movements prominent in today's educational arena, it is imperative that educators be prepared for change in their organization. In order for an educator to be an effective change agent, he or she must be proactive and be as knowledgeable about the change as possible so that effective organizational change theory can be applied.

Block scheduling is one such change that many educators will need to explore. There is much literature available regarding the effects of block scheduling (Hurley, 1997; Edwards, 1995), but a more concentrated study on the differences between groupings of students as they move from traditional to block scheduling may provide a better understanding as to what is really involved in this change. This dissertation will not focus on the effects of block scheduling on these groupings. There are too many independent variables involved to state that block scheduling alone would be the reason for the changes in student attitude, attendance, or academic achievement in this study. Instead, the study will focus on the differences in attitude, attendance and achievement of the various groups of students moving from a traditional schedule to a modified $4 \times 4$ block schedule format. The purpose of this dissertation is to provide information about these groups of students so that educators can be more knowledgeable about the change to block scheduling before deciding on whether or not to initiate the change in their organization.

\section{Statement of the Problem}

This investigator will identify the differences in groups of students' achievement, attendance, and attitude as high school students move from a traditional to a block schedule. To study various groups, the high school students will be grouped into 
quartiles based on their grade point averages under the traditional schedule. Specifically, the following questions will be answered.

1. What differences are seen in student achievement as the groups of students move from a traditional to a modified $4 \times 4$ block schedule?

2. What differences in student attendance can be seen as the groups of students move from a traditional to a modified $4 \times 4$ block schedule?

3. What differences in student attitude can be seen as the groups of students move from a traditional to a modified $4 \times 4$ block schedule?

Justification/Need for the Study

As an educational leader, it is important to understand the way that change affects organizations so that one can give direction and guide the organization through the process. There are many types of changes to which an organization is subjected, and there is no question that most change is inevitable. There are situations, however, where the educational leader has the opportunity to decide whether or not his organization will undergo a change. Whenever an educational leader has this opportunity, it is most important to know in detail the benefits and pitfalls of the change, as well as who within the organization will be affected and how they will be affected.

Much research has been done on the effects that block scheduling has had on schools, staff and students (Canady, 1998), (Rettig and Canady, 1999). This research is important in helping educational leaders gain the knowledge of the advantages and disadvantages that this change can induce. The broader the base of research the better informed our educational leaders will be in making a decision on whether or not to change the organizational structure. 
There is currently little research available regarding specific groupings of students and block scheduling. Sandra K. Wayne (1998) wrote a dissertation, The Implications of Changing to a Block Schedule for Learning Disabled Students. Karen Santos and Michael Rettig (1998) wrote an article, "Meeting the Needs of Special Education Students in a High School Block Schedule." George N. Franks (1999) wrote a dissertation, Block Scheduling and Its Impact on the Academic Achievement and Behavior of Students in a High School with Regard to Gender: An Exploratory Study. Only the dissertation by Franks included research on students grouped according to their academic achievement. This dissertation also made comparisons with groupings of students, although the groupings were not determined from academic achievement.

This study will be of benefit to the field of educational leadership in that it is important to understand whether or not the change to block scheduling can create differences in students or groups of students. The results of this dissertation will help to narrow the focus in deciding for whom the change to block scheduling can really make a difference. The findings from this study will help educational administrators to determine whether the change to a modified $4 \times 4$ block schedule will help to improve the education of specific groups of students within their school population. In turn, this data will allow them to make a well-informed decision on whether or not the change to block scheduling is worthwhile to their organization.

Definition of Terms

Organizational Change -- A term used to refer to the processes that enable systems and individuals to achieve the goal of maximizing student learning (Glatthorn, 1997).

Traditional Schedule -- For the purpose of this study, the traditional schedule is one that involves a standard six to eight-period day, where class length is less than 60 minutes. 
Block Scheduling -- Block Scheduling is a form of high school scheduling where classes meet for a time block of 90 minutes or more (Canady and Rettig, 1995).

Four by Four Block Schedule -- The $4 \times 4$ schedule is a form of high school scheduling where class meets for a time block of 90 minutes or more. Students are required to take four classes each semester (Canady and Rettig, 1995).

Academic Achievement -- For the purpose of this study, the term, academic achievement, will mean improvement in grade point average from the traditional year of instruction to the block schedule year of instruction.

Grouping of Students -- Students will be grouped for the purpose of this study according to their academic rank by grade point average as of the 1997-98 school year. The groupings will consist of four quartiles, with the first quartile representing the top 25 percent of the students, the second quartile representing the next 25 percent of the students (26-50\%), the third quartile representing the next 25 percent of the students (51-75\%) and the fourth quartile representing the last 25 percent of the students (76$100 \%)$.

Limitations

The subjects for this study were limited to students from a selected high school, geographically located in the Northern Panhandle of West Virginia and the Upper Ohio Valley region of Ohio. The anonymity of students is maintained in this study. The results obtained from the grouped students may not be representative of other grouped students. The duration of the study was delimited to a one year period of time, and this may not be an ample amount of time to reveal the long-term effects of the study.

The student responses to this questionnaire may be attributable, in part, to extraneous factors (grading periods, conflict situations) that occurred during the academic year.

There are several factors that limit the results of this study. There are a variety of variables that may have had positive or negative impacts on the results of this study 
during the change from the traditional schedule to a modified $4 \times 4$ block schedule. Some of these variables include: changes in student and/or staff personal lives, staff turnover, staff acceptance of the change to block scheduling, the amount of staff development and preparation given, the amount of supervision by the principal, and the type of block schedule which is implemented.

To successfully implement the change from the traditional schedule to the block schedule, professional staff development took place during the 1997-98 academic year, i.e., groups of teachers, department heads, and others participated in visitation, inservices, and contacted resource people to garner an in-depth knowledge base and to have questions answered. 


\section{$\underline{\text { Summary }}$}

Any organizational change has the potential to cause problems within that organization if the organizational leader does not implement the change effectively. It is extremely important to be educated on many aspects of a change prior to implementation in order to be proactive as a leader.

Block scheduling is an organizational change in education that is being implemented at a rapid rate in schools across the United States today. This study will help educational leaders see some of the ways that the change from a traditional schedule to a modified $4 \times 4$ block schedule affects all students as well as particular groupings of students. In addition, the differences, if any, between these particular groupings will be revealed. The educational leader can use this information to determine if the change to a modified $4 \times 4$ block scheduling will prove beneficial to his/her school.

Chapter Two is a review of literature used to develop the ideas for this dissertation. Organizational change theory is explored in this chapter as well as the development of the scheduling format in the United States. An in-depth investigation of block scheduling and its advantages are included in this chapter. Research is also included in regard to student grouping, attendance, attitude and academic achievement.

Chapter Three is an explanation of the research methods used in this dissertation. A description of the subjects, and how the research will be done is included in this chapter. Chapter Four is a description of the results of the research and Chapter Five includes the conclusions made based on the results of this study. 


\section{CHAPTER TWO}

\section{Review of Literature}

\section{Overview}

The literature selected for review in this study is divided into three parts: organizational change, the history of high school scheduling, and block scheduling. The major emphasis of this review of literature section will be placed on block scheduling. The background of scheduling, in general, the implications, positives and negatives of block scheduling, and the impact of block scheduling on academic achievement, attitude, and attendance and student grouping will be covered in this review of literature.

\section{Organizational Change}

Organizational Change is an important process in restructuring for positive results in schools. Lunenburg and Orstein (2000) define organizational change as an attempt by school executives to improve the effectiveness of schools (p. 211). As mentioned in Chapter One, integrating the different perspectives and the ability to reconceptualize around which the change is focused is critical to the success of the change. Bolman and Deal (1997) emphasize this point in their book, Reframing Organizations. Holtzman (1993) stresses the importance of understanding what true systemic change means and the complete dynamics of the process.

According to Lunenburg and Orstein (2000), the pressures for organizational change takes place generally because of external and internal pressure that emanates from "government intervention, society's values, changing technology and knowledge explosion, and administrative processes, and fulfillment of employees' needs" (p. 208).

Senge (1990) defines the learning organization as "organizations where people continually expand their capacity to create the results they truly desire, where new and expansive patterns of thinking are nurtured, where collective aspiration is set free and where people are continually learning how to learn together" (p. 3). 
Although, Fullan (1991) explains that we frequently do not know what we are truly after or appreciate the consequences of pursuing it until after we have already begun the effort (p. 5). People interpret change in an over-simplified way, adopting it without truly understanding it (1991, p. 70). Fullan (1991) continues by asserting that however unintentionally, change can worsen the conditions of teaching, or it can provide the "support, stimulation, and pressure to improve" (p. 26). Evans (1996) feels that administrators need to understand the causes of resistance to change.

Senge (1990, pp. 219-220) delineates different degrees of support people can have for an organization's vision:

Commitment: Wants it. Will make it happen. Creates whatever "laws" structures are needed.

Enrollment: Wants it. Will do whatever can be done within the "spirit of the law."

Genuine Compliance: Sees the benefits of the vision. Does everything expected and more. "Good soldier."

Formal Compliance: On the whole, sees the benefits of the vision. Does what is expected and no more. "Pretty good soldier."

Grudging Compliance: Does not see the benefits of the vision. But, also does not want to lose a job. Does enough of what's expected because he has to, but also lets it be known that he is not really on board.

Noncompliance: Does not see the benefits of the vision and will not do what's expected. "I won't do it; you can't make me."

Apathy: Neither for or against vision. No interest. No energy. "Is it five o'clock yet?"

It is the role of the principal to see that teachers are involved and supported. Fullan (1991) explains that principals should reflect on their role as leaders, "some see 
themselves as promoters of change, others don't" (p. 167). Evans (1996) indicates that it is important to be clear of the leadership role (p. 195).

The leadership role should be one collaboration (Fullan, Hargreaves, 1996). "It is not enough for teachers to be involved, it is the kind of involvement that really matters if meaningful change is take place" (p. 15). Marsh (1999) notes that the school day does not encourage the teachers to be reflective individually or with other professionals (p. 187). The daily life of a teacher has not evolved as much as one would hope, even with the turn of the millennium (Sarason, 1996).

Duke (1998) asserts that "if the designers of new learning environments -teachers, administrators -- are up to the task, we will witness schools in which high standards of learning and conduct are maintained without diminishing the hopes of any group of students" (p. 693). Understanding the stages of changes and analyzing where an organization is on the continuum of educational change is important as Anderson (1993) states in her article, "The Stages of Systemic Change." Much literature prepared from classes taken over the past nine years has provided insight, as well, in preparation for this study, stressing the importance of a strong knowledge base pertaining to the change at hand and proactive leadership.

History of High School Scheduling

Canady and Rettig (1995) state that the Committee of Ten's Report in 1893 mandated the "formation of the rigidly structured high school schedule as we know it today" (p. 13). The result of the Committee of Ten's report "was to encourage every high school to center the work of each student upon five or six academic areas in each of the four high school years" (Gorman, 1971, p. 114). This has not always been the case in the American High School Schedule. Prior to the National Education Association's Committee of Ten's report in 1892, Latin Grammar Schools and high schools of that era incorporated flexibility into their scheduling practices where students took subjects on a two to four-day a week schedule (Gorman, 1971). 
According to Boyer (1983), in 1909 the Carnegie Foundation proposed "a standard unit to measure high school work based on time,' with "a total of 120 hours in one subject -- meeting 4 or 5 times a week, for 40 to 60 minutes, for 36 to 40 weeks each year -- earning the student one "unit of high school credit" (p. 60). Boyer (1983), also stated that "The Carnegie Unit became a convenient, mechanical way to measure academic progress throughout the country" (p. 60). Eineder (1996) stated, "The introduction of the Carnegie Unit unified the organizational patterns of high schools across the nation" (p. 16). According to Kruse and Kruse (1995), "Our view of time and learning has been shaped by the Carnegie standard unit measurement in which student seat-time in a given curriculum area is equated to completion or mastery of that subject" (p. 2). They also stated that "the Carnegie standard unit was directly tied to the industrial standardization reforms of that time in which a certain quantity of time was directly related to more efficient production" (p. 2).

King (1996) noted that in the early 1920s, the Dalton Plan was created by Helen Farkhurst. This Plan, according to King, "broke from the factory model and restructured the school day into subject labs with students determining their individual daily schedules" (p. 19).

Additionally, she wrote, "...students were viewed as trustworthy people entitled to considerable say about how they spent their time" (pp. 19-20). The Dalton Plan failed, however. O'Neil (1995) offered that students were too often left unsupervised, thus causing discipline problems. Furthermore, he noted that too much time was spent in independent study.

According to Canady and Rettig (1995), J. Lloyd Trump developed a design of a flexible modular schedule in 1959. The model offered by Trump allowed for varying lengths of instructional time. Canady and Rettig reported, "Students would spend their time in a variety of instructional formats -- large groups (100 or more), small group, and individual study -- depending on the needs of students and subjects" (p. 14). 
Canady and Rettig (1995), expressed that previously the flexible modular scheduling was received positively by students and teachers. Canady and Rettig (1995) and Goldman (1983) indicated that teachers and students preferred flexible modular high school schedules over traditional schedules, but that parents and community members were less enthusiastic about flexible modular scheduling. Goldman (1983) stated that student achievement in schools with flexible modular scheduling was no better than schools with traditional schedules.

According to Canady and Rettig (1995) and Goldman (1983), flexible modular scheduling presented two major concerns. The first concern was centered on unscheduled student time. Students would typically spend 30 to 40 percent of the school day in independent study and individualized tutoring; thus there was an increase in discipline issues. The second concern focused on teacher behavior, primarily methodology. Goldman (1983) wrote that teachers had difficulty adjusting their instruction to irregular lengths of class time.

As stated by Canady and Rettig (1995), "the experience with flexible modular scheduling faded by the late 1980 s and early 1990s. At the same time, however, they noted that schools began to re-examine high school scheduling practices with the intention of eliminating or reducing the dependency on the lock-step, daily, single-period schedule..." (p. 15). According to Canady and Rettig (1995), in the end "most high schools returned to traditional schedules primarily because of a number of problems with flexible modular scheduling, most related to student discipline" (p. 14).

Carroll (1994) indicated that the introduction of a new schedule model, the Copernican Plan, challenged the notion that all schedules should be centered on the Carnegie unit. According to Carroll (1994), the Copernican Plan is based on the idea of more effective instruction. Carroll (1994) wrote that more effective instruction could take place if the use of instructional time by teachers and students accommodated better instructional practices. Carroll (1994) asserted that high schools based on the 
Carnegie Unit prevented effective instruction by teachers and effective learning by students. Conversely, he wrote, "The Copernican Plan challenges what has become an article of faith -- the Carnegie Unit" (p. 106). In a high school with a Copernican schedule, students typically were taught in 75 to 100 minute classes. A four-year study done by Carroll (1994), where the Copernican Plan was used in a high school, led to the following findings:

1. Teachers felt more productive and portrayed a sense of rejuvenation by incorporating different methodologies into their instruction.

2. Students felt better known by their teachers, received personalized care from their teachers, were more challenged, completed more writing assignments, studied issues in greater detail, and gained deeper understandings of relevant topics.

3. Students completed over 13 percent more course credits than their traditionally scheduled counterparts.

4. Students had comparable levels of retention with their traditionally scheduled counterparts.

The Copernican Plan, according to Carroll (1994), created a new way of thinking of how time played a role in the school schedule. The National Education Commission on Time and Learning (1994) determined that, "Learning in America is a prisoner of time" (p. 7). The Commission reported:

The school clock governs how families organize their lives, how administrators oversee their schools, and how teachers work their way through the curriculum. Above all, it governs how material is presented to students and the opportunity they have to comprehend and master it (p. 8.). 
The Commission reported that schools should rely much less on the 40 to 50 minute class and implement an expanded time schedule. The Commission expressed that, "Block scheduling, the use of two or more periods for exploration of complex topics or for science laboratories, should become more common..." (p. 2).

According to Canady and Rettig (1995), there has been little change in scheduling practices since this time, and several attempts at altering the scheduling practices during these years were made with little or no success (Canady \& Rettig, 1995; Goldman, 1993; King, 1996).

Fiske (1991) feels that anything short of fundamental structural change in the current system of public education is futile. There is a need to prepare students for the twenty-first century, to emphasize the capacity of students to think, learn, create, and solve problems.

Block Scheduling

Over the last decade, growing numbers of high schools across the United States decided to implement various forms of block scheduling (Eineder, 1996). Cawelti wrote in 1984 that 11 percent of American high schools were using some form of block scheduling and more than 15 percent had plans to implement a form of block scheduling. The number has since grown to over 40 percent according to several sources. Cawelti (1994) wrote, "The most visible and perhaps significant change in the organization of the high school has been the block schedule" (p. 41).

Canady and Rettig (1998), (DiRocco, 1998-1999) maintain there is an increase in positive outcomes, as well as increase in teacher and student satisfaction when longer blocks of time are scheduled into one semester. Bevevino (1999, p. 13) concludes that "the application of curriculum requirements to the semester block schedule allows for considerable variations." 
There are several variation styles of block scheduling, but most seem to be derived from either the A/B Block Schedule or the $4 \times 4$ Block Schedule. The most significant difference between a traditional and a block schedule is the length of courses on a daily basis and the length of class on a yearly basis. In a traditional class, there are seven or eight classes per day, ranging from 40 to 50 minutes in length. These classes usually extend across the full school year. The following is an example of a yearly class schedule under the traditional schedule. 


\section{Example 1}

YEARLY TRADITIONAL CLASS SCHEDULE

\begin{tabular}{|l|l|}
\hline Semester 1 & Semester 2 \\
\hline & Class 1 \\
\hline Class 2 \\
\hline Class 3 \\
\hline Class 4 \\
\hline Class 5 \\
\hline Class 6 \\
\hline Class 7 \\
\hline Class 8 \\
\hline
\end{tabular}

The following is an example of a weekly class schedule under the traditional schedule.

\section{Example 2}

\section{TRADITIONAL WEEKLY CLASS SCHEDULE}

\begin{tabular}{|c|c|c|c|c|c|}
\hline & Mon & Tues & Wed & Thur & Fri \\
\hline Per 1 & Class 1 & Class 1 & Class 1 & Class 1 & Class 1 \\
\hline Per 2 & Class 2 & Class 2 & Class 2 & Class 2 & Class 2 \\
\hline Per 3 & Class 3 & Class 3 & Class 3 & Class 3 & Class 3 \\
\hline Per 4 & Class 4 & Class 4 & Class 4 & Class 4 & Class 4 \\
\hline Per 5 & Class 5 & Class 5 & Class 5 & Class 5 & Class 5 \\
\hline Per 6 & Class 6 & Class 6 & Class 6 & Class 6 & Class 6 \\
\hline Per 7 & Class 7 & Class 7 & Class 7 & Class 7 & Class 7 \\
\hline Per 8 & Class 8 & Class 8 & Class 8 & Class 8 & Class 8 \\
\hline
\end{tabular}

In the $A / B$, or alternating day, block schedule, there are usually four classes per day. These classes are approximately 90 minutes in length. The classes are offered every other day with usually some form of variation in schedule on the fifth day of the week. These classes usually extend across the full school year. The following is an example of a yearly class schedule under the A/B block schedule. 


\section{Example 3}

YEARLY A/B BLOCK CLASS SCHEDULE

\begin{tabular}{|c|}
\hline Sem 1 \\
\hline Class $1 \&$ 2 alternating days \\
\hline Class 3 \& 4 alternating days \\
\hline Class 5 \& 6 alternating days \\
\hline Class 7 \& alternating days \\
\hline
\end{tabular}

The following is an example of a weekly class schedule under the A/B Block Schedule.

\section{Example 4}

WEEKLY A/B BLOCK CLASS SCHEDULE

\begin{tabular}{|l|l|l|l|l|l|}
\hline & Mon & Tues & Wed & Thur & Fri \\
\hline Per 1 & Class 1 & Class 5 & Class 1 & Class 5 & Class 1 \\
\hline Per 2 & Class 1 & Class 5 & Class 1 & Class 5 & Class 2 \\
\hline Per 3 & Class 2 & Class 6 & Class 2 & Class 6 & Class 3 \\
\hline Per 4 & Class 2 & Class 6 & Class 2 & Class 6 & Class 4 \\
\hline Per 5 & Class 3 & Class 7 & Class 3 & Class 7 & Class 5 \\
\hline Per 6 & Class 3 & Class 7 & Class 3 & Class 7 & Class 6 \\
\hline Per 7 & Class 4 & Class 8 & Class 4 & Class 8 & Class 7 \\
\hline Per 8 & Class 4 & Class 8 & Class 4 & Class 8 & Class 8 \\
\hline
\end{tabular}

In the $4 \times 4$ Block Schedule, there are usually four classes per day. These classes are approximately 90 minutes in length. The classes are offered every semester. These classes usually extend across one half of the school year. The following is an example of a yearly class schedule under the $4 \times 4$ block schedule. 


\section{Example 5}

\section{YEARLY 4 X 4 BLOCK CLASS SCHEDULE}

\begin{tabular}{|c|c|}
\hline 1st Sem & 2nd Sem \\
\hline Class 1 & Class 5 \\
\hline Class 2 & Class 6 \\
\hline Class 3 & Class 7 \\
\hline Class 4 & Class 8 \\
\hline
\end{tabular}

The following is an example of a weekly class schedule under the $4 \times 4$ Block Schedule, taking into consideration that the other four classes in the second semester would follow the same format.

\section{Example 6}

WEEKLY 4 X 4 BLOCK CLASS SCHEDULE

\begin{tabular}{|l|c|c|c|c|c|}
\hline & Mon & Tues & Wed & Thur & Fri \\
\hline Per 1 & Class 1 & Class 1 & Class 1 & Class 1 & Class 1 \\
\hline Per 2 & Class 2 & Class 2 & Class 2 & Class 2 & Class 2 \\
\hline Per 3 & Class 3 & Class 3 & Class 3 & Class 3 & Class 3 \\
\hline Per 4 & Class 4 & Class 4 & Class 4 & Class 4 & Class 4 \\
\hline
\end{tabular}

In a modified $4 \times 4$ Block Schedule, there is usually some combination of the traditional and the $4 \times 4$ Block Schedule. The following is one example of a yearly class schedule under a modified $4 \times 4$ block schedule.

\section{Example 7}

YEARLY MODIFIED 4 X 4 BLOCK CLASS SCHEDULE

\begin{tabular}{|l|l|}
\hline 1st Sem & 2nd Sem \\
\hline Class 1 & Class 6 \\
\hline Class 2 & Class 7 \\
\hline Class 3 & Class 8 \\
\hline \multicolumn{2}{|c|}{ Class 4 } \\
\hline \multicolumn{2}{|c|}{ Class 5 } \\
\hline
\end{tabular}


The following is an example of a weekly class schedule under a modified $4 \times 4$ Block Schedule, taking into consideration that there would be three other classes in the second semester that would follow the same format as the first three classes in the first semester.

\section{Example 8}

WEEKLY MODIFIED 4 X 4 BLOCK CLASS SCHEDULE

\begin{tabular}{|l|l|l|l|l|l|}
\hline & Mon & Tues & Wed & Thur & Fri \\
\hline Per 1 & Class 1 & Class 1 & Class 1 & Class 1 & Class 1 \\
\hline Per 2 & Class 2 & Class 2 & Class 2 & Class 2 & Class 2 \\
\hline Per 3 & Class 3 & Class 3 & Class 3 & Class 3 & Class 3 \\
\hline Per 4 & Class 4 & Class 4 & Class 4 & Class 4 & Class 4 \\
\hline Per 5 & Class 5 & Class 5 & Class 5 & Class 5 & Class 5 \\
\hline
\end{tabular}

Duke (May, 1998, p. 693) maintains, "If the nation's leaders are going to insist on high learning standards for students, let them honor consistency enough to demand high standards for the settings in which students are expected to learn."

Much of the information gathered in preparation for this investigation of block scheduling was initiated from information in the book, Block Scheduling: A Catalyst for Change in High Schools by Robert Lynn Canady and Michael Rettig (1995). There has also been a proliferation of information regarding the effects of block scheduling on students, teachers, and schools overall.

\section{Impact on Instructional Strategies}

Canady and Rettig (1995) stated that one of the most important factors in the success of block scheduling is the degree in which teachers alter their instructional practices. They wrote, "...teachers should be provided time to alter their curriculum appropriately and get training in suitable instructional strategies that will be effective in the block" (pp. 21-22). Canady and Rettig (1995) offer that a "major need which must be addressed with the implementation of block scheduling is helping teachers gain the 
necessary strategies and skills to teach successfully in a large block of time" (p. 205). They wrote:

We predict that the single most important factor in determining the success or failure of block scheduling programs will be the degree to which teachers successfully alter instruction to utilize extended time blocks effectively. If instructional practices do not change, the block scheduling movement of the 1990s, like the flexible modular scheduling movement of the 1960s and 1970s, will be buried in the graveyard of failed educational innovations (p. 22).

Tewel (1991) wrote, "Ignoring the special needs of the school staff when the organization is in transition may be the reason why so many high school restructuring efforts fail, or, at best, have limited success" (p. 81). Canady and Rettig (1995) indicated that in order to incorporate instructional strategies that will facilitate success in block scheduling, the teacher staff should be "...provided with a minimum of five, and hopefully ten days, of staff development" (p. 205). They reported that staff development prescribed by these researchers should involve a large amount of engagement by the staff. Additionally, they wrote, "In these workshops, strategies must be modeled for teachers who later must design instruction for students in large blocks of time" (p. 206).

Shortt and Thayer (1995), report that teachers are required to think differently about instruction within the block-scheduling format. They noted that "block scheduling permitted greater amounts of time for student learning, laboratory work, and student directed interactive activities" (p. 75). Canady and Rettig (1995) supported this idea by stating that "The short single periods offered by most scheduling models limit flexibility in terms of the kinds of instructional strategies that can be accomplished" (p. 8). Miller (1992) added that "The traditional schedule fosters lecture style classes that emphasize coverage rather than reflection, discussion, and thoughtful analysis" (p. 6). 
Glasser (1992) maintains that students should not be penalized for taking more time than allowed by the schedule to finish their work successfully. Scheduling flexible blocks of time for instruction is a shift from the fixed time slot of fifty-minute classes in the traditional setting.

Canady and Rettig (1995) emphasize the importance of varying learning time. They state that "Perhaps the most critical (and unresolved) time allocation issue that schools face is the indisputable fact that some students need more time to learn than others" (p. 5).

According to Hackman (1995), when instruction occurs in block scheduling, "...teachers may assume that they can fit two 'old' lessons into this time frame" (p. 1). Hackman (1995) suggested that "Teachers soon learn, however, that they cannot take this approach of using the same methods they did before" (p. 1). Canady and Rettig (1995) additionally noted that teachers would be ineffective if they simply combine two 45-minute lessons into one block period. Therefore, they asserted that "...activities must be reorganized within the new time frame" (p. 9).

Canady and Rettig (1998) wrote that teachers in block-scheduled schools should plan lessons with at least three distinct activities in the block period, and that "The two most difficult aspects of a lesson plan for teachers seem to be developing and implementing the application phase of a lesson and managing the transitions within the block" (p. 30). In addition they indicated that lesson pacing within block scheduling tends to present problems for many teachers. As a solution, Sessoms (1995) and Tanner (1996), suggested that staff development be adjusted accordingly to incorporate those strategies to help facilitate the success of block scheduling. The following fourteen instructional techniques were listed by Renzulli as most often used by high school teachers:

recitation and drill; peer tutoring; lecture; lecture/discussion; discussion; guided independent study; learning/interest center; 
simulation, role playing, dramatization, guided fantasy; learning

games; replicative reports or projects; investigative reports or

projects; unguided independent study; internship; and

apprenticeship (p. 52).

Instructional blocks of extended time segments give teachers more instructional flexibility (Sizer, 1990; Carroll, 1990).

To maximize the effect of block scheduling, Canady and Rettig (1995) suggested that teachers use instructional strategies that engage active learners. In addition, Cawelti (1994) asserted that teachers were more likely to accommodate individual learning styles when more than one instructional strategy was incorporated into the lesson. Sparks (1996) reported that "teachers can improve the learning and achievement of all students through well-designed instructional practices" (p. 59).

Concerning the need for instructional change, Canady and Rettig (1995) indicated the importance for teachers to alter their instructional practices. Marshak (1997) expressed that teachers within a block scheduling format have a much larger space, a broader stage, and it is on this stage that they create their new practice" (p. 8). He added that "if teachers refuse to create new instructional practices, students are much more likely to move beyond boredom into anger and active rather than passive resistance" (p. 8).

Marshak (1997) described several key components to the success of block scheduling:

1. Lecture has a place in the repertoire of the block-period teacher, but its use must be limited to its appropriate functions.

2. If the teacher is a skilled and engaging speaker, lecture might also be used as one mode of presenting information and ideas. Effective lecturers are usually good storytellers, 
but the key to the use of lecture is skill.

3. In contrast to short periods, block periods require a variety of teaching and learning activities both within each period and over a number of block periods.

4. In addition to an increased variety of teacher-structured and teacher-led activities, block periods allow, and eventually require, an increase in the extent to which students are active as learners and to which they set directions for their own learning. As teachers provide students with the opportunities for self-direction, they must also help students develop the skills of selfregulation, which effective self-directed learning requires.

5. One class structure that works well in block periods both for teacher-led and student-directed activities is the use of cooperative groups. Students need to be taught how to become skilled group members.

6. Over time, the use of block periods will change the structure of curriculum. Block periods provide time to study material in greater depth. As teachers and students study topics in greater depth, and as students become more active as learners do, the whole notion of covering the curriculum will change. The focus of teachers' concerns moves from coverage to student learning.

7. A key indicator of the success of block period classes is the level of student involvement in the learning. Block 
periods challenge teachers to enact their larger roles as leaders and coaches, as well as resources of information, and to create classrooms where students are consistently engaged in their learning.

8. The implementation of block periods encourages teachers and students to explore and experiment. For teachers, in particular, some level of ongoing experimentation is crucial if they are to develop and maintain a creative edge in their professional work (pp. 24-28).

Anderson (1994) wrote, "In order to maintain sufficient student motivation, teachers would have to vary their methods and the activities by which they would engage students in learning" (p. 28). Hottenstein and Malatesta (1993), O'Neil (1995), and Schoenstein (1995) reported that teachers involved in block scheduled schools tend to individualize instruction, use more instructional strategies, and use cooperative learning more extensively than teachers involved in traditionally scheduled schools.

\section{Benefits of Block Scheduling}

Cawelti (1994) identified the following benefits of block scheduling: (a) class periods are lengthened; (b) the number of class changes is reduced, thus reducing the number of discipline infractions; (c) planning time for teachers is increased; (d) the number of preparations for teachers is reduced; (e) teachers can develop closer relationships with their students; (f) there is an opportunity for alternative forms of assessment, there is an opportunity for additional help for students, and there is a better opportunity for interdisciplinary teaching.

In addition, Canady and Rettig $(1993,1995,1998)$, report the following as benefits of block scheduling: (a) teachers and students report that the school day is less stressful; (b) discipline problems are reduced; (c) teachers are responsible for fewer classes, therefore fewer students, each term; (d) students and teachers have to 
prepare for fewer classes; (e) fewer textbooks are needed; (f) teachers' daily recordkeeping is reduced; $(\mathrm{g})$ instructional time is increased; $(\mathrm{h})$ students can repeat a failed course during the regular school year; (i) teachers use a variety of instructional methodologies; (j) students see fewer teachers each term, and (k) students can graduate in three years.

Hampton (1997), also lists several additional benefits of block scheduling: (a) time savings; (b) increased opportunities for project work; (c) higher attendance rates; (d) higher number of students on the honor roll; (e) fewer interruptions during the course of the day; and (f) a greater chance for at-risk students to work with teachers.

Carroll (1994), in The Copernican Plan, suggests that a concentrated schedule is more likely to result in positive, academic achievement, attendance, discipline, and standardized test scores. In agreement, DiRocco (1998-1999) notes that "Intensive schedules can be a powerful catalyst for change and for improved instruction in our secondary schools when implemented properly" (p. 83). Edwards (1995) maintains that by implementing the $4 \times 4$ block schedule, students have "twice the opportunity to complete required courses as the four-year, 180-day schedule" (p. 16).

Students reported they liked the modified $4 \times 4$ block schedule because it allowed for more time for in-depth study, they received more individual attention from the teacher, they were getting better grades and their lives were less hectic (Hurley, 1997, p. 65).

Teachers speak to the benefits of scheduling (Hurley, 1997) saying that it improves working conditions. "They like having fewer students to work with at a given time, more planning time, fewer class preparations, and a more relaxed daily schedule" (p. 54).

The extended schedule provides a more positive school climate (Canady, Rettig, 1995). "A more positive school climate and more in-depth learning opportunities are 
complemented by an increase in the number of courses that a student is able to complete within the four years of high school" (Bevevino, et al, 1999, p. 6).

Inhibitors of Block Scheduling

Based on their experiences, Canady and Rettig $(1995,1998)$ have identified numerous possible inhibitors in the $4 \times 4$ block scheduling: (a) the scheduling of transfer of students is more difficult; (b) scheduling electives and certain year-long courses, such as music, may be a problem; (c) student absences are viewed as a greater problem; (d) balancing the difficulty of student schedules can be a problem; (e) some teachers report a problem with instructional pacing; (f) the retention of learned material is a concern from one year to the next; $(\mathrm{g})$ scheduling of 'AP' courses is a concern; and (h) vocational school students' schedules may be affected.

According to a report by the Northwest Regional Education Laboratory (1990), "Imposing a scheduling model on a school will not ensure success" (p. 51). This report recommended a minimum of two years of planning time before the implementation of alternative scheduling. While not solving all these issues, but to minimize the inhibitors of block scheduling, Canady and Rettig (1995) stated that adequate staff development was essential to the success of block scheduling. They further noted that teachers typically required additional training in the areas of cooperative learning, class building, and team formation.

In agreement, O'Neil (1995) explains that "One is ensuring that the instruction offered in block classes is appropriate for the longer format" (p. 14). "The assertion is that longer classes can support instructional innovations but that does not necessarily happen. The effective use of class time can be an advantage/disadvantage contradiction" (Hurley, 1997, p. 58). Hurley (1997) reports that teachers sometimes give less homework or they give more homework allowing the students to do homework in class. 
The Importance of Block Scheduling on Academic Achievement

According to Canady and Rettig (1998), there have been relatively few controlled studies conducted on block scheduling as related to academic achievement. They noted that the results of the impact of block scheduling on academic achievement are encouraging, nonetheless. They stated, "There is consistent evidence that students' grades, as reported by grade point averages, increase and the number of students on the A, B Honor Roll increases" (p. 20). Similarly, Edwards (1995) reported that the percentage of 'A's' rose 7 percent, while Hottenstein and Malatesta (1993) reported more students were on the honor roll and fewer students received 'D's' an 'F's.'

According to Sizer (1999), the traditional school routines have little to do with success where the students are measured by the scores accrued from subjects being taught in isolation. Additionally, Littky and Allen (1999) note that the traditional high school schedule makes it almost impossible for students and teachers to establish the relationship needed to guide students on a personal level and an academic level. Bush (1998) also notes "...true and natural learners are often unrecognized and overlooked" (p. 46). Discussing the engaged learner, she goes on to say that engaged learners sometimes come from the "least likely sources" (p. 46).

Snyder (1997), comparing baseline data from the previous two years, reported highly significant improvements in school-wide grade point averages. He also reported a "significant increase in the percentage of students on the honor roll, while the results on the Indiana State Proficiency Exams improved to some of the highest scores in the area" (p. 1).

Snyder (1997) also reported that students under block scheduling made significant improvements in school-wide grade point averages, semester and final exams, and ACT scores. In addition, he reported "more students achieved honor roll status with the block schedule" (p. 4). 
Eineder (1996) reported students under block scheduling achieved significantly higher cumulative grade point averages. In addition, he noted that block scheduling resulted in a significant increase in the number of students achieving honor roll status.

Strock and Hottenstein (1994), reporting from data used during the first year of block scheduling, posited that "grades are up, more students are on the honor roll, and fewer students are receiving D and F grades or incompletes"

(p. 31). After two years of implementing the $4 \times 4$ block schedule, Fitzpatrick and Mowers (1997) noted that teacher class loads were reduced from 125 to 75 students, behavior referrals were reduced by 23 percent, and honor roll numbers and overall grade point averages increased (pp. 51-56).

Reid, Hierck, and Veregin (1994) reported similar findings from a school with grades 10 to 12 . The failure rate for 10 th grade students declined in four out of five subject areas tested by the province of British Columbia. In the 11th grade, they reported the failure rate declined in eight out of nine subject areas, while the failure rate declined in six out of nine subject areas for 12th grade students. In addition, they determined that students achieving honor roll status increased by 50 percent and the graduation rate increased by 20 percent.

Edwards (1993), reflecting on a 1991-1992 pilot program for academically at-risk students at a high school in Virginia, reported that block scheduling had a positive impact on student performance. He noted that 76 percent (16 of 21) of the students improved their performance over the previous year. According to Edwards (1993), because of this improvement, the overall failure rate decreased by 5 percent.

Munroe (1989) also noted that block scheduling had a positive impact on students who were labeled academically at-risk. Reporting on the results of a pilot program at a school in Arizona, she reported an increase in student grade point averages and the number of classes completed. 


\section{Impact on Students}

One of the outcomes to be measured in this study is attitude. There is a variety of information regarding the effect of block scheduling on climate and attitude. Bevevino, Snodgrass, Adams, and Dengel (1999) in An Educator's Guide to Block Scheduling, cite sources with results indicating that student attitude and climate are improved. Similar results can be found in articles written by Rettig and Canady (1996, 1999), Queen and Gaskey (1997), Shortt and Thayer (1999), and Skrobarcek, Chang, et al. (1997).

The second and third outcomes measured in this study are academic achievement and attendance. Rettig and Canady $(1996,1999)$ cite specific sources where grades and attendance have improved with block scheduling. Other authors of articles, studies, and dissertations which support this notion include Wilson (1995), Shortt and Thayer (1999), Queen and Gaskey (1997), Geismar and Pullease (1996), Shoenstein (1995), and Skrobarcek, Chang, et al. (1997). All of these pieces of literature indicate improvement in course grades, grade point averages, honor roll numbers and/or attendance.

Again, as stated in Chapter One, there has been much research and literature on the effects of block scheduling, but very little to none in the area of how block scheduling affects different student groupings. The current literature that has been reviewed regarding different groupings of students entails specific groups of students, such as special needs students, at-risk students or gifted students. Although helpful in understanding the needs of these groups of students, the literature does not address the differences between groups which is needed to explain why the students should be grouped for this study.

Littky and Allen (1999) address the need for instructional decisions to meet the needs of "kids in the middle" (p. 25). Alluding to the fact that curriculum does not fit all students, especially the middle group, they postulate a need for "personalized learning" 
(p. 26) that allows students to develop their "passions and interests to bring them back to the group instead of competing with one another on one set of goals" (p. 26). The relationship established with the teacher must be one where the teacher knows of their backgrounds, personalities, and educational histories so that instructional decisions can enhance the learning environment (Littky \& Allen, 1999).

\section{Groupings and The Block}

Elizabeth Cohen (1998) addresses making groups equitable. "Low status" group members usually think less and are less listened to than students in "high status" (p. 19) groups. High status groups usually talk more, listen less, and are listened to more than other students. The inequality of groups and the assumed characteristics of the groups, as well as perceived expectations, are often misunderstood. Cohen (1998) stresses "The failure to participate does not come from the personality...," and to make groups more equitable, perceptions and expectations for "competence" and "incompetence" (p. 19) must be changed. Changing the expectations of groups and including the "multiple, intellectual abilities treatment" (p. 20) can reduce the participatory differences among groups of varying abilities.

Scherer (1998) discussing the change in curriculum suggests that curriculum must be "...shaped not only from what adults know but also from how kids learn..." ( $p$. 12). Nelson (1999), in his article, "The Emperor Redux," believes there are "highly educated adults" (p. 392) who do have the ability to create environments that address the needs of every student. He goes on to say, "...young people should be valued and affirmed..." (p. 392).

This affirmation is reiterated by Folasade Oladele (1999), a classroom teacher, as she notes: I establish high expectations and a single standard: Nothing but their best was acceptable. As its center was my understanding that all my students had something to contribute. Because I believed that they all could learn, I taught my students to believe in 
themselves (p. 64).

Oladele (1999) reveals that the changes in her students' lack of interest, poor attitude, and lazy behavior were "powerful changes."

Cohen (1998) also supports the affirmation of all groups of students by stating, "...competence is not simply a treatment for low-status students..."

(p. 21). Covey (1989) reaffirms the need to build positive relationships and the need to understand other people before we can expect them to understand us.

The implementation of block scheduling empowers the teacher to organize the instruction to accommodate the various abilities of the students, not the subject matter. The flexible scheduling permits students to take advantage of all resources available to them guided by educators who care more about students than just covering the text. Empowered teachers, in the redesigned curriculum, maximizes student learning using relationships to “...connect learners to knowledge and application” (Littky \& Allen, 1999, p. 27-28).

Shortt and Thayer (1998-99) state that a teacher who was a critic of block scheduling, after the implementation of block scheduling for a semester, renewed her commitment to teaching. The increased instructional time gave way to "...grouping students on the basis of student needs" (p. 77). In their study, achievement gains were calculated by comparing urban, suburban, and rural schools that had implemented block scheduling to those on a traditional schedule. The findings in Figure 1, revealed that "both types of block scheduled schools outperformed single-period schools in all but one instance" (pp. 79-80). "It is important to note that the $4 \times 4$ sampling is small" (p. 80). The implementation of alternating day scheduling, DiRocco (1998-1999) at a Lewisburg, Pennsylvania middle school has resulted in "improved academic performance by students" (p. 82). Teachers were empowered to make instructional decisions as to the variability of instruction utilized in longer class periods. Considering 
all factors, it was still concluded that block scheduling had an improved effect on student performance.

Figure 1

\begin{tabular}{|c|c|c|c|}
\hline \multicolumn{5}{|c|}{ PERCENTILE GAINS ON 11TH GRADE NORM-REFERENCED TEST } \\
\multicolumn{1}{|c|}{ 1996-1997, BY TYPE OF SCHEDULE } \\
\hline TYPE OF SCHOOL & NUMBER OF SCHOOLS & READING GAIN & MATHEMATICAL \\
& 62 & & GAIN \\
\hline A-B & 56 & 3.14 & 3.60 \\
\hline $4 \times 4$ & 161 & 2.61 & 3.02 \\
\hline SINGLE PERIOD & & 2.30 & 2.34 \\
\hline
\end{tabular}

(Shortt \& Thayer, 1998-1999, p. 80) 


\section{Summary}

Once the leadership role and functions have been clearly delineated, instructional decision, namely restructuring with regard to high school scheduling can be implemented. Teachers, more now than ever, are being empowered to make instructional decisions based on the needs, interests, and abilities of all students and all groups of students.

The paradigm shift from the traditional model of scheduling to block scheduling has given opportunity for the synergistic relationship (Bonsting, 1992) to exist. This relationship is created and enhanced by the talents of all students instructed by a variety of models. Proponents of block scheduling allude to the effectiveness of instruction at both ends of the spectrum, but the intent is for all students to gain in the instructional environment (Sizer, 1999).

The review of literature reveals that restructuring the curriculum to block scheduling does have an impact on students' behavior, attendance, attitude, and achievement. While much of the research reviewed reveal positive implications for the at-risk (Munroe, 1989) and gifted groups of students, minimal research has been conducted to give evidence as to whether or not various quartile groups of students benefit from block scheduling.

The literature reviewed does indicate the need and results of grouping within the group, tracking vs. detracking, and the expectations and perceptions of lower-status students and higher-status students. The literature reveals an increased emphasis on the shift from the traditional schedule to block scheduling and how this shift relates to positive results in attendance, student behavior, attitude, and overall achievement. Although the literature reviewed reveals the importance and benefits of block scheduling, there is a void in the research to give evidence that a relationship might exist between block scheduling and the various quartiles of students, especially the middle quartile students. The research in this study is designed to determine the 
achievement, attitude, attendance, and behavior in the grouping of students by quartiles (indicating ability levels) as they moved from the traditional schedule to a modified $4 \times 4$ block schedule. 


\section{CHAPTER THREE}

Research Methods and Procedures

The purpose of this study was to determine the differences in groupings of students' academic achievement, attitude and attendance as a school made the change from a traditional schedule to a modified $4 \times 4$ block schedule.

- What differences are seen in student achievement as the groups of students move from a traditional to a modified $4 \times 4$ block schedule.

- What differences in student attendance can be seen as the groups of students move from a traditional to a modified $4 \times 4$ block schedule.

- What differences in student attitude can be seen as the groups of students move from a traditional to a modified $4 \times 4$ block schedule.

\section{Demographics}

The high school targeted for this study was a small, urban high school in the Midwest. The total population for this school during the 1997-98 school year was 860, and for the 1998-99 school year, the enrollment was 876 . The professional staff for both the 1997-98 and 1998-99 school year consisted of 62 teachers, two administrators, three guidance counselors and one part time nurse. The student minority population in the school was 31.4 percent during the 1997-98 school year, with 34 percent of all students during this year eligible for free or reduced lunch. During the 1998-99 school year the high school had a 31.5 percent minority population with 33.8 percent of all students during this year eligible for free or reduced lunch. 


\section{Participants}

The participants eligible for this study consisted of all members of the sophomore, junior and senior classes during the 1998-99 school year who had attended the same high school during the 1997-98 school year. The sophomore class during the 1998-99 school year yielded a population of 214 and a sample size of eligible participants of 187 for this study. The junior classes for the 1998-99 school year yielded a population of 209 and a sample size of eligible participants of 197 . The senior class for the 1998-99 school year yielded a population of 224 and a sample size of eligible participants of 196. The schedule for the 1997-98 school year in this high school was traditional, with seven instructional periods of 45 to 50 minutes. The high school implemented a modified 4x4 block schedule during the 1998-99 school year. Design

The factors researched in this study were academic achievement, attendance and attitude. These factors were analyzed descriptively, as a whole, and within the specific groupings established for this study. All students involved had attended the school chosen for this study during the 1997-98 school year under a traditional schedule and the 1998-99 school year under a modified 4x4 block schedule.

The students were grouped for the purpose of this study to measure attendance, academic achievement and attitude according to their academic ranking for the 199798 school year. The student population was distributed into quartiles within each grade for all eligible students according to the following guidelines established for this study.

- The first quartile represents the top 25 percent academically achieving students based on grade point averages for the 1997-98 school year, 
- The second quartile represents the second 25 percent academically achieving students based on grade point averages for the 1997-98 school year.

- The third quartile represents the third 25 percent academically achieving students based on grade point averages for the 1997-98 school year.

- The fourth quartile represents the lowest 25 percent academically achieving students for the 1997-98 school year.

POPULATION-SAMPLE

Sophomores 1998-1999

Figure 1

\begin{tabular}{|c|c|c|c|c|c|}
\hline Quartiles & Q1 & Q2 & Q3 & Q4 & TOTAL \\
\hline Population & 53 & 54 & 54 & 53 & 214 \\
\hline Sample & 46 & 49 & 48 & 44 & 187 \\
\hline
\end{tabular}

The first quartile (highest academically achieving students) from the 1998-99 sophomore class had a population of 53 and a sample size of 46 . The second quartile from the 1998-99 sophomore class had a population of 54 and a sample size of 49 . The third quartile from the 1998-99 sophomore class had a population of 54 and a sample size of 48 . The fourth quartile from the $1998-99$ sophomore class had a population of 53 and a sample size of 44 . 


\section{POPULATION - SAMPLE}

Juniors 1998-1999

Figure 2

\begin{tabular}{|c|c|c|c|c|c|}
\hline Quartiles & Q1 & Q2 & Q3 & Q4 & TOTAL \\
\hline Population & 52 & 53 & 52 & 52 & 209 \\
\hline Sample & 50 & 52 & 50 & 45 & 197 \\
\hline
\end{tabular}

The first quartile from the 1998-99 junior class had a population of 52 and a sample size of 50 . The second quartile from the 1998-99 junior class had a population of 53 and a sample size of 52 . The third quartile from the 1998-99 junior class had a population of 52 and a sample size of 50 . The fourth quartile from the 1998-99 junior class had a population of 52 and a sample size of 45 . 


\section{POPULATION-SAMPLE}

Seniors 1998-1999

Figure 3

\begin{tabular}{|c|c|c|c|c|c|}
\hline Quartiles & Q1 & Q2 & Q3 & Q4 & TOTAL \\
\hline Population & 56 & 56 & 56 & 56 & 224 \\
\hline Sample & 54 & 52 & 47 & 43 & 196 \\
\hline
\end{tabular}

The first quartile (highest academically achieving students) from the 1998-99 senior class had a population of 56 and a sample size of 54 . The second quartile from the 1998-99 senior class had a population of 56 and a sample size of 52 . The third quartile from the 1998-99 senior class had a population of 56 and a sample size of 47 . The fourth quartile from the 1998-99 senior class had a population of 56 and a sample size of 43 .

POPULATION-SAMPLE

Aggregate 1998-1999

Figure 4

\begin{tabular}{|c|c|c|c|c|c|}
\hline Quartiles & Q1 & Q2 & Q3 & Q4 & TOTAL \\
\hline Population & 161 & 163 & 162 & 161 & 647 \\
\hline Sample & 150 & 153 & 145 & 132 & 580 \\
\hline
\end{tabular}

Overall for all students, the first quartile (highest academically achieving students) had a population of 161 and a sample size of 150 . The second had a population of 163 and a sample size of 153 . The third quartile had a population of 162 
and a sample size of 145 . The fourth quartile had a population of 161 and a sample size of 132.

Data

The primary source of data involving student achievement and attendance was obtained from official school records. Official records were kept at the school chosen for this study and The Ohio Department of Education also has copies of this information stored in its computer system. Any other researcher who intends on replicating this study would have these records available $\underline{\text { Instrument }}$

Data with regards to student attitude were collected through an instrument developed specifically to determine student attitude. This instrument was created by Dr. R. Lynn Canady, Professor of Educational Leadership and Policy Studies at the University of Virginia and M. D. Kelly, Associate Professor at James Madison University. This questionnaire was developed early in the stages of studying block scheduling and has been utilized in research studies conducted in block scheduling. The original questionnaire was modified by adding one question to ensure that all respondents had indeed attended the target school for both the 1997-98 school year and the 1998-99 school year (Appendix A).

\section{Procedure}

The researcher received approval from the superintendent of the school district where the targeted high school is located to study the school schedule in April of 1999 (Appendix B). Additionally, the researcher was granted approval from the Human 
Subjects Review Committee from the institution in which this study was undertaken (Appendix C).

In January of 1999, all data with regard to academic achievement and attendance for the 1997-98 school year were gathered from the targeted school. In February of 1999 the quartiles to be used for the study were established based on the grade point averages of the students for the 1997-98 school year.

In May of 1999 the parents of the students, who were minors during the time of the study, were asked to sign a consent form (Appendix D), and all participants were asked to fill out an assent form (Appendix E). All students eligible to participate in the study were asked to complete the attitude questionnaire on May 27, 1999.

In June of 1999 data with regard to academic achievement and attendance for the 1998-99 school year were gathered from the targeted school. Students meeting all criteria to be participants in the study were identified by their appropriate quartiles at that time.

All eligible students for this study were asked to fill out a questionnaire to determine student attitude. The total possible number of students eligible for this study was 580 . Four hundred forty eight students responded to the questionnaire for a 77.2 percent return rate.

\section{RATE OF RETURN}

1998-1999

Figure 5

\begin{tabular}{|c|c|c|c|c|c|c|c|}
\hline RESPONDENTS & Q1 & Q2 & Q3 & Q4 & $\begin{array}{c}\text { TOTAL RATE } \\
\text { OF RETURN }\end{array}$ & $\begin{array}{c}\text { TOTAL } \\
\text { SAMPLE }\end{array}$ & $\begin{array}{c}\text { \% RATE } \\
\text { OF RETURN }\end{array}$ \\
\hline SOPHOMORES & 37 & 36 & 40 & 26 & 139 & 187 & $74.3 \%$ \\
\hline JUNIORS & 46 & 46 & 42 & 40 & 174 & 197 & $88.3 \%$ \\
\hline
\end{tabular}




\begin{tabular}{|c|c|c|c|c|c|c|c|}
\hline SENIORS & 47 & 44 & 31 & 13 & 435 & 196 & $68.8 \%$ \\
\hline $\begin{array}{c}\text { AGGREGATE RATE } \\
\text { OF RETURN }\end{array}$ & & & & & 448 & 580 & $77.2 \%$ \\
\hline
\end{tabular}

The 1998-99 sophomore class had an overall return rate on the survey of 74.3 percent. The first quartile from the sophomore class had 37 respondents. The second quartile had 36 respondents. The third quartile from the sophomore class had 40 respondents. The fourth quartile from sophomore class had 26 respondents.

The 1998-99 junior class had an overall return rate on the survey of 88.3 percent. The first quartile from the junior class had 46 respondents. The second quartile had 46 respondents. The third quartile from the junior class had 42 respondents. The fourth quartile from the junior class had 40 respondents.

The 1998-99 senior class had an overall return rate on the survey of 68.8 percent. The first quartile from the senior class had 47 respondents. The second quartile had 44 respondents. The third quartile from the senior class had 31 respondents. The fourth quartile from the senior class had 13 respondents. Analysis of Data

The students' academic progress was tracked over a two-year period by a comparison of a student's $1997-98$ grade point average to the student's $1998-99$ grade point average. A student's change in grade point average was denoted by a (+) indicating improvement or a ( - ) indicating regression. A numerical value was assigned to the amount of change the student had made in grade point average. All grades were based on a 4.0 to 0.0 scale. These data were obtained from official school records from the targeted school. 
The students' academic progress was analyzed descriptively by comparing the progress within the quartiles by class and overall as a school. Data collected within a group were compiled in two ways. An overall percentage of improvement and regression was established and an overall mean improvement or regression was established.

The students' attendance trend was tracked over a two-year period by a comparison of a student's attendance during the 1997-98 school year to the student's attendance during the 1998-99 school year. A student's change in attendance was denoted by a (+), indicating improvement, or a ( - ) indicating regression. A numerical value was assigned to the amount of change in attendance from the previous year's statistic. These data were obtained from official school records from the targeted school.

The students' attendance was analyzed descriptively by comparing the progress within the quartiles by class and overall as a school. The data collected within a group were compiled in two ways. An overall percentage of improvement and regression was established and an overall mean improvement or regression was established.

The students' attitude was determined through a questionnaire (Appendix A) containing 25 questions with a space for additional comments at the end of the questionnaire. The responses to the questions were in multiple choice format, and were arranged in a manner similar to a Likert type scale. The questionnaire was administered once toward the end of the 1998-99 school year.

A descriptive analysis of each question as it pertained to the groups was completed to assess student attitude. The responses to each question were compared 
between the quartiles in each class as well as through the quartiles of the school as a whole. Data within a quartile were compiled by taking the number and percentage of responses to each possible answer. 


\section{CHAPTER FOUR}

Analysis and Results

This study investigated the difference in groupings of students' academic achievement, attendance, and attitude as they moved from a traditional to a modified $4 \times 4$ block schedule at a targeted high school. The schedule for the 1997-98 school year in this high school was traditional, with seven instructional periods of 45 to 50 minutes. The high school implemented a modified $4 \times 4$ block schedule during the 199899 school year.

Overview of the Study

The participants of this study consisted of all members of the sophomore, junior and senior classes during the 1998-99 school year who attended the same high school during the 1997-98 school year. The students in each grade were separated into quartiles according to their grade point averages from the 1997-98 school year. The sophomore class during the 1998-99 school year yielded a population of 214 and a sample size of eligible participants of 187 for this study. The junior class for the 199899 school year yielded a population of 209 and a sample size of eligible participants of 197. The senior class for the 1998-99 school year yielded a population of 224 and a sample size of eligible participants of 196 .

The research questions guiding this study were:

- What differences are seen in student achievement as the groups of students move from a traditional to a modified $4 \times 4$ block schedule?

- What differences in student attendance can be seen as the groups of students move from a traditional to a modified $4 \times 4$ block schedule? 
- What differences in student attitude can be seen as the groups of students move from a traditional to a modified $4 \times 4$ block schedule?

Data collected and analyzed descriptively in this study consisted of data for grade point average and attendance, and student responses to a survey to determine attitude toward block scheduling was subject to content analysis. The results of these analyses are organized into three sections: (a) academic achievement; (b) student attendance; and (c) student attitude.

$\underline{\text { Student Achievement }}$

All student achievement information was gathered from school records and student records. These data were descriptively analyzed from the total student sample, within the quartiles established for the overall school sample, and through the quartiles established within each grade.

The grade point averages of all students who met the sampling criteria were examined both during the 1997-98 school year and then again during the 1998-99 school year. Table 1 shows the mean grade point average of all of the sampled students by quartile within each grade level for the 1997-98 school

Table 1

MEAN GRADE POINT AVERAGE BY QUARTILE WITHIN EACH GRADE LEVEL FOR THE 1997-98 SCHOOL YEAR

\begin{tabular}{|l|c|c|c|c|c|}
\hline & Sample & Q1 & Q2 & Q3 & Q4 \\
\hline SR & 196 & $3.5552(\mathrm{n}=54)$ & $2.7458(\mathrm{n}=52)$ & $1.9619(\mathrm{n}=47)$ & $0.8878(\mathrm{n}=43)$ \\
\hline JR & 197 & $3.6985(\mathrm{n}=50)$ & $2.5602(\mathrm{n}=52)$ & $1.8505(\mathrm{n}=50)$ & $0.7512(\mathrm{n}=45)$ \\
\hline SO & 187 & $3.5287(\mathrm{n}=46)$ & $2.5845(\mathrm{n}=49)$ & $1.9422(\mathrm{n}=48)$ & $0.7511(\mathrm{n}=44)$ \\
\hline & $580 \mathrm{x}:$ & $3.5948(\mathrm{n}=150)$ & $2.6311(\mathrm{n}=153)$ & $1.9170(\mathrm{n}=145)$ & $0.7957(\mathrm{n}=132)$ \\
\hline
\end{tabular}

year. Table 2 illustrates the mean grade point average of all of these sampled students for the 1998-99 school year in their same groups. 
Table 2

MEAN GRADE POINT AVERAGE BY QUARTILE WITHIN EACH GRADE LEVEL FOR THE 1998-99 SCHOOL YEAR

\begin{tabular}{|l|c|c|c|c|c|}
\hline & Sample & Q1 & Q2 & Q3 & Q4 \\
\hline SR & 196 & $3.5748(n=54)$ & $2.8390(\mathrm{n}=52)$ & $2.0582(\mathrm{n}=47)$ & $0.9398(\mathrm{n}=43)$ \\
\hline JR & 197 & $3.7433(\mathrm{n}=50)$ & $2.6276(\mathrm{n}=52)$ & $1.9577(\mathrm{n}=50)$ & $0.6631(\mathrm{n}=45)$ \\
\hline SO & 187 & $3.5766(\mathrm{n}=46)$ & $2.6986(\mathrm{n}=49)$ & $2.0345(\mathrm{n}=48)$ & $0.6953(\mathrm{n}=44)$ \\
\hline & $580 \mathrm{x}:$ & $3.6315(\mathrm{n}=150)$ & $2.7222(\mathrm{n}=153)$ & $2.0156(\mathrm{n}=145)$ & $0.7640(\mathrm{n}=132)$ \\
\hline
\end{tabular}

There are some obvious differences in the scores of the sampled students as a whole as well as in quartile groups as they progressed through the block schedule year. Table 3 shows the mean grade point average score difference by quartile from the 1997-98 school year to the 1998-99 school year.

Table 3

MEAN GRADE POINT AVERAGE SCORE DIFFERENCE BY QUARTILE FROM THE 1997-98 SCHOOL YEAR TO THE 1998-99 SCHOOL YEAR.

\begin{tabular}{|l|c|c|c|c|c|}
\hline & Sample & Q1 & Q2 & Q3 & Q4 \\
\hline SR & 196 & $+.020(\mathrm{n}=54)$ & $+.093(\mathrm{n}=52)$ & $+.096(\mathrm{n}=47)$ & $+.052(\mathrm{n}=43)$ \\
\hline JR & 197 & $+.045(\mathrm{n}=50)$ & $+.067(\mathrm{n}=52)$ & $+.107(\mathrm{n}=50)$ & $-.088(\mathrm{n}=45)$ \\
\hline SO & 187 & $+.048(\mathrm{n}=46)$ & $+.114(\mathrm{n}=49)$ & $+.092(\mathrm{n}=48)$ & $-.056(\mathrm{n}=44)$ \\
\hline & $580 \mathrm{x}:$ & $+.037(\mathrm{n}=150)$ & $+.091(\mathrm{n}=153)$ & $+.099(\mathrm{n}=145)$ & $-.032(\mathrm{n}=132)$ \\
\hline
\end{tabular}

From the total student body the analysis showed that the students in the first three quartiles all showed positive growth in grade point average, while the students in fourth quartile showed a decrease in grade point average. In analyzing the quartiles within each particular grade level it was found that each quartile showed positive growth with the exception of the $10^{\text {th }}$ grade fourth quartile and the $11^{\text {th }}$ grade fourth quartile.

A closer look at Table 3 revealed that there were some large differences between the students in the second and third quartile as compared to students in the first and the fourth quartile. In the second quartile, students showed a mean growth in 
grade point average of .091 points while the students in the third quartile showed a mean growth of .099 points. These improvements are nearly triple the average amount of improvement made by first quartile students, who had a mean growth of .037 points. Students in the fourth quartile showed an overall mean decrease of .032 points in grade point average. In fact, in analyzing each quartile within the grade levels, the highest six of the 12 quartiles showing improvement all came from the second or third quartiles of each grade.

In addition to mean scores within the quartiles, each quartile was examined to determine the number and percentage of students who improved their grade point average during the block schedule year. Table 4 shows percentage of students within each quartile who had improved their grade point average from the 1997-98 school year to the 1998-99 school year.

There are differences in the percentages of the sampled students as a whole as well as in quartile groups as they progressed through the block schedule year. Table 4 shows the percentage of students who showed improvement in their grade point averages by quartile from the 1997-98 school year to the 1998-99 school year. From the total student body the analysis showed that the students in the first three quartiles all showed over half of their sampled members with an increase in grade point average. The students in the fourth quartile had less than 50 percent of its sampled students showing growth in grade point average. In analyzing the quartiles within each particular grade level it was found that each quartile showed over half of the students showed improvement in grade point average with the exception of the $12^{\text {th }}$ grade first quartile, the $10^{\text {th }}$ grade fourth quartile, and the $11^{\text {th }}$ grade fourth quartile. 
Table 4

PERCENTAGE OF STUDENTS WITHIN EACH QUARTILE WHO HAD IMPROVED THEIR GRADE POINT AVERAGE FROM THE 1997-98 SCHOOL YEAR TO THE 1998-99 SCHOOL YEAR.

\begin{tabular}{|l|c|c|c|c|c|}
\hline & Sample & Q1 & Q2 & Q3 & Q4 \\
\hline SR & 196 & $46 \%(\mathrm{n}=25)$ & $71 \%(\mathrm{n}=37)$ & $74 \%(\mathrm{n}=35)$ & $56 \%(\mathrm{n}=24)$ \\
\hline JR & 197 & $64 \%(\mathrm{n}=32)$ & $77 \%(\mathrm{n}=40)$ & $60 \%(\mathrm{n}=30)$ & $29 \%(\mathrm{n}=13)$ \\
\hline SO & 187 & $52 \%(\mathrm{n}=24)$ & $67 \%(\mathrm{n}=33)$ & $63 \%(\mathrm{n}=30)$ & $41 \%(\mathrm{n}=18)$ \\
\hline & $580 \mathrm{x}:$ & $54 \%(\mathrm{n}=81)$ & $72 \%(\mathrm{n}=110)$ & $66 \%(\mathrm{n}=95)$ & $42 \%(\mathrm{n}=55)$ \\
\hline
\end{tabular}

A closer look at Table 4 shows that there were some substantial differences between the second and third quartile students as compared to the first and the fourth quartile students. Seventy-two percent of the second quartile students showed improvement in grade point average while 66 percent of the students in the third quartile showed improvement in this area. Fifty-four percent of the first quartile students and 42 percent of the fourth quartile students overall showed an increase in grade point average.

In fact, in analyzing each quartile within the grade levels, all six of the quartiles by grade in the second or third quartiles had at least 60 percent of its students showing improvement in grade point average. Only one of the six quartiles by grade in the first and fourth quartiles had at least 60 percent improvement in grade point average and the junior students in the fourth quartile had only 29 percent of its students showing improvement. 


\section{Student Attendance}

All student attendance information was gathered from school records and student records. These data were descriptively analyzed from the total student sample, within the quartiles established for the overall school sample, and through the quartiles established within each grade.

The absences of all students who met the sampling criteria were examined both during the 1997-98 school year and then again during the 1998-99 school year. Table 5 shows the mean number of student absences by quartile within each grade level for the 1997-98 school year.

\section{Table 5}

MEAN NUMBER OF STUDENT ABSENCES BY QUARTILE WITHIN EACH GRADE LEVEL FOR THE 1997-98 SCHOOL YEAR

\begin{tabular}{|l|c|c|c|c|c|}
\hline & Sample & Q1 & Q2 & Q3 & Q4 \\
\hline SR & 196 & $5.76(\mathrm{n}=54)$ & $13.46(\mathrm{n}=52)$ & $22.89(\mathrm{n}=47)$ & $23.19(\mathrm{n}=43)$ \\
\hline JR & 197 & $5.60(\mathrm{n}=50)$ & $13.69(\mathrm{n}=52)$ & $18.42(\mathrm{n}=50)$ & $27.00(\mathrm{n}=45)$ \\
\hline SO & 187 & $5.64(\mathrm{n}=46)$ & $13.08(\mathrm{n}=49)$ & $15.34(\mathrm{n}=48)$ & $18.78(\mathrm{n}=44)$ \\
\hline & $580 \mathrm{x}:$ & $5.69(\mathrm{n}=150)$ & $13.42(\mathrm{n}=153)$ & $18.85(\mathrm{n}=145)$ & $23.03(\mathrm{n}=132)$ \\
\hline
\end{tabular}

Table 6 illustrates the mean number of absences of all of these sampled students for the 1998-99 school year in their same groups.

\section{Table 6}

MEAN NUMBER OF STUDENT ABSENCES BY QUARTILE WITHIN EACH GRADE LEVEL FOR THE 1998-99 SCHOOL YEAR

\begin{tabular}{|l|c|c|c|c|c|}
\hline & Sample & Q1 & Q2 & Q3 & Q4 \\
\hline SR & 196 & $5.50(\mathrm{n}=54)$ & $8.29(\mathrm{n}=52)$ & $13.02(\mathrm{n}=47)$ & $19.17(\mathrm{n}=43)$ \\
\hline JR & 197 & $3.42(\mathrm{n}=50)$ & $7.52(\mathrm{n}=52)$ & $10.60(\mathrm{n}=50)$ & $23.44(\mathrm{n}=45)$ \\
\hline SO & 187 & $3.59(\mathrm{n}=46)$ & $7.52(\mathrm{n}=49)$ & $9.46(\mathrm{n}=48)$ & $16.19(\mathrm{n}=44)$ \\
\hline & $580 \mathrm{x}:$ & $4.22(\mathrm{n}=150)$ & $7.78(\mathrm{n}=153)$ & $11.02(\mathrm{n}=145)$ & $19.57(\mathrm{n}=132)$ \\
\hline
\end{tabular}


There are noticeable differences in the mean number of absences of the sampled students as a whole, as well as in the quartile groups as they progressed through the block schedule year. Table 7 shows the mean student absence improvement by quartile from the 1997-98 school year to the 1998-99 school year. 


\section{Table 7}

MEAN STUDENT ABSENCE IMPROVEMENT BY QUARTILE FROM THE 1997-98 SCHOOL YEAR TO

THE 1998-99 SCHOOL YEAR.

\begin{tabular}{|l|c|c|c|c|c|}
\hline & Sample & Q1 & Q2 & Q3 & Q4 \\
\hline SR & 196 & $+0.26(\mathrm{n}=54)$ & $+5.17(\mathrm{n}=52)$ & $+9.87(\mathrm{n}=47)$ & $+4.02(\mathrm{n}=43)$ \\
\hline JR & 197 & $+2.18(\mathrm{n}=50)$ & $+6.17(\mathrm{n}=52)$ & $+7.82(\mathrm{n}=50)$ & $+3.56(\mathrm{n}=45)$ \\
\hline SO & 187 & $+2.10(\mathrm{n}=46)$ & $+5.56(\mathrm{n}=49)$ & $+5.88(\mathrm{n}=48)$ & $+2.59(\mathrm{n}=44)$ \\
\hline & $580 \mathrm{x}:$ & $+1.47(\mathrm{n}=150)$ & $+5.64(\mathrm{n}=153)$ & $+7.83(\mathrm{n}=145)$ & $+3.46(\mathrm{n}=132)$ \\
\hline
\end{tabular}

From the total student body the analysis revealed that students in all four quartiles all showed improvement in their attendance, but there was a large range in the amount of improvement when comparing the quartiles to each other. The students in the third quartile had an average improvement in attendance of 7.83 days while the students in the second quartile had an average improvement in attendance of 5.64 days. The fourth quartile students improved their attendance by 3.46 days on average while the first quartile students averaged 1.36 days of improvement in attendance.

In addition there were differences between the second and third quartile students by grade as compared to the first and the fourth quartile students by grade. The highest six of the 12 quartiles showing improvement all came from the second or third quartiles of each grade. The average improvement in attendance in each of these quartiles was at least 5.5 days with the senior third quartile having the most improved attendance with a mean improvement 9.87 days. In contrast, neither the first nor the fourth quartile students at any grade had an average improvement of 4.5 or higher and the senior first quartile students only had a mean improvement of .26 days.

In addition to mean scores within the quartiles, each quartile was examined to determine the number and percentage of students who improved their attendance 
during the block schedule year. Table 8 shows percentage of students within each quartile who had improved their attendance from the 1997-98 school year to the 199899 school year.

There are differences in the percentages of the sampled students as a whole as well as in quartile groups as they progressed through the block

\section{Table 8}

PERCENTAGE OF STUDENTS WITHIN EACH QUARTILE WHO HAD IMPROVED THEIR ATTENDANCE FROM THE 1997-98 SCHOOL YEAR TO THE 1998-99 SCHOOL YEAR.

\begin{tabular}{|l|c|c|c|c|c|}
\hline & Sample & Q1 & Q2 & Q3 & Q4 \\
\hline SR & 196 & $48 \%(\mathrm{n}=26)$ & $75 \%(\mathrm{n}=39)$ & $85 \%(\mathrm{n}=40)$ & $63 \%(\mathrm{n}=27)$ \\
\hline $\mathrm{JR}$ & 197 & $44 \%(\mathrm{n}=22)$ & $73 \%(\mathrm{n}=38)$ & $68 \%(\mathrm{n}=34)$ & $49 \%(\mathrm{n}=22)$ \\
\hline SO & 187 & $54 \%(\mathrm{n}=25)$ & $71 \%(\mathrm{n}=35)$ & $67 \%(\mathrm{n}=32)$ & $59 \%(\mathrm{n}=26)$ \\
\hline & $580 \mathrm{x}:$ & $49 \%(\mathrm{n}=73)$ & $73 \%(\mathrm{n}=112)$ & $73 \%(\mathrm{n}=106)$ & $57 \%(\mathrm{n}=75)$ \\
\hline
\end{tabular}

schedule year. Table 8 shows the percentage of students who showed_improvement in their attendance by quartile from the 1997-98 school year to the 1998-99 school year. From the total student body the analysis showed that the students in the last three quartiles all showed over half of their sampled members with an increase in attendance. The students in first quartile had less than 50 percent of its sampled students showing growth in attendance. In analyzing the quartiles within each particular grade level it was found that each quartile showed over half of the students showed improvement in attendance with the exception of the $12^{\text {th }}$ grade first quartile, the $11^{\text {th }}$ grade first quartile, and the $11^{\text {th }}$ grade fourth quartile.

A closer look at Table 8 shows that there were some substantial differences between the second and third quartile students as compared to the first and the fourth quartile students. Seventy-three percent of the second and third quartile students 
showed improvement in attendance while 49 percent of the first quartile students and 57 percent of the fourth quartile students overall showed an increase in attendance. In addition, in analyzing the quartiles within the grade levels, all six of the quartiles by grade in the second or third quartiles had at least 67 percent of its students showing improvement in attendance. None of the six quartiles by grade in the first and fourth quartiles achieved this percentage of improvement.

Student Attitude

All student attitude information was gathered from a student survey (Appendix A). This survey consisted of 26 questions, the first 25 of which were multiple choice. Each set of responses to a question was analyzed individually. These data were analyzed from the total student sample responses, within the quartiles established for the overall school sample, and through the quartiles established within each grade.

\section{Question 1: Last year I attended Steubenville High School (circle one) True False}

Question One was used on this survey to insure that all participants in this survey did indeed meet the criteria established to be a member of the sample used for this study. The sample size that was established for this study was 448 . All 448 participants responded true to this question. Table 9 illustrates the responses to this question from the students grouped according to their quartile and grade. 
Table 9

SUMMARY OF STUDENT RESPONSES BY QUARTILE AND AS A WHOLE TO QUESTION 1 OF THE ATTITUDE QUESTIONNAIRE

\begin{tabular}{|c|c|c|c|c|}
\hline & & TRUE & FALSE & TOTALS \\
\hline SR & Q1 & 47 & 0 & 47 \\
\hline & Q2 & 44 & 0 & 44 \\
\hline & Q3 & 31 & 0 & 31 \\
\hline & Q4 & 13 & 0 & 13 \\
\hline JR & Q1 & 46 & 0 & 46 \\
\hline & Q2 & 46 & 0 & 46 \\
\hline & Q3 & 42 & 0 & 42 \\
\hline & Q4 & 40 & 0 & 40 \\
\hline SO & Q1 & 37 & 0 & 37 \\
\hline & Q2 & 36 & 0 & 36 \\
\hline & Q3 & 40 & 0 & 40 \\
\hline ALL & Q4 & 26 & 0 & 26 \\
\hline & Q1 & 130 & 0 & 130 \\
\hline & Q2 & 126 & 0 & 126 \\
\hline & Q3 & 113 & 0 & 113 \\
\hline & Q4 & 79 & 0 & 79 \\
\hline & TOTALS & 448 & 0 & 448 \\
\hline
\end{tabular}

Question 2: This year I am in grade

$$
A=09 \quad B=10 \quad C-11 \quad D=12
$$

All students accurately responded to the grade level to which they were associated.

The sophomore sample size for this survey was 139 . The junior sample size for this survey was 174 . The senior sample size for this survey was 135 . Table 10 shows the responses to this question from the students grouped according to their quartile and grade.

Question 3: With the new block schedule this year, I believe I am

understanding my lessons better than last year.

A -- strongly agree; B -- agree; C -- disagree;

$D$-- strongly disagree; E -- no difference between this year 
and last year.

Table 10

SUMMARY OF STUDENT RESPONSES BY QUARTILE AND AS A WHOLE TO QUESTION 2 OF THE ATTITUDE QUESTIONNAIRE

\begin{tabular}{|c|c|c|c|c|c|c|}
\hline & & $\begin{array}{c}\text { A } \\
\text { FRESHMAN }\end{array}$ & $\begin{array}{c}\text { B } \\
\text { SOPHOMORE }\end{array}$ & $\begin{array}{c}\mathrm{C} \\
\text { JUNIOR }\end{array}$ & $\begin{array}{c}\text { D } \\
\text { SENIOR }\end{array}$ & TOTALS \\
\hline \multirow[t]{4}{*}{ SR } & Q1 & \begin{tabular}{|l|}
0 \\
\end{tabular} & 0 & 0 & 47 & 47 \\
\hline & $\mathrm{Q} 2$ & 0 & 0 & 0 & 44 & 44 \\
\hline & Q3 & 0 & 0 & 0 & 31 & 31 \\
\hline & $\mathrm{Q} 4$ & 0 & 0 & 0 & 13 & 13 \\
\hline \multirow[t]{4}{*}{$\mathrm{JR}$} & Q1 & 0 & 0 & 46 & 0 & 46 \\
\hline & Q2 & 0 & 0 & 46 & 0 & 46 \\
\hline & Q3 & 0 & 0 & 42 & 0 & 42 \\
\hline & $\mathrm{Q} 4$ & 0 & 0 & 40 & 0 & 40 \\
\hline \multirow[t]{4}{*}{ SO } & Q1 & 0 & 37 & 0 & 0 & 37 \\
\hline & $\mathrm{Q} 2$ & 0 & 36 & 0 & 0 & 36 \\
\hline & Q3 & 0 & 40 & 0 & 0 & 40 \\
\hline & Q4 & 0 & 26 & 0 & 0 & 26 \\
\hline \multirow[t]{5}{*}{ ALL } & $\mathrm{Q} 1$ & 0 & 37 & 46 & 47 & 130 \\
\hline & Q2 & 0 & 36 & 46 & 44 & 126 \\
\hline & Q3 & 0 & 40 & 42 & 31 & 113 \\
\hline & Q4 & 0 & 26 & 40 & 13 & 79 \\
\hline & TOTALS & 0 & 139 & 174 & 135 & 448 \\
\hline
\end{tabular}

Table 11 shows the responses to this question from the students grouped according to their quartile and grade. From the total student sample, 23 percent $(n=105)$ of the students responded that they saw no change between the two years. The majority of the students responded favorably toward the block schedule (55\% or $n=242)$, and of these students 30 percent $(n=72)$ strongly agreed that the block schedule had a positive impact on their understanding of their lessons. Twenty-three percent $(n=101)$ of the students felt they understood lessons better in the traditional schedule. 
Table 11

SUMMARY OF STUDENT RESPONSES BY QUARTILE AND AS A WHOLE TO QUESTION 3 OF THE ATTITUDE QUESTIONNAIRE

\begin{tabular}{|l|l|c|c|c|c|c|c|}
\hline & & $\begin{array}{c}\text { A Strongly } \\
\text { Agree }\end{array}$ & $\begin{array}{c}\text { B } \\
\text { Agree }\end{array}$ & $\begin{array}{c}\text { C } \\
\text { Disagree }\end{array}$ & $\begin{array}{c}\text { D Strongly } \\
\text { Disagree }\end{array}$ & $\begin{array}{c}\text { E } \\
\text { No } \\
\text { Difference } \\
\text { This } \\
\text { Year/Last } \\
\text { Year }\end{array}$ & TOTALS \\
\hline SR & Q1 & 6 & 18 & 6 & 7 & 10 & 47 \\
\hline & Q2 & 10 & 15 & 2 & 6 & 11 & 44 \\
\hline & Q3 & 5 & 11 & 3 & 4 & 8 & 31 \\
\hline & Q4 & 1 & 5 & 1 & 2 & 4 & 13 \\
\hline JR & Q1 & 7 & 17 & 4 & 7 & 11 & 46 \\
\hline & Q2 & 9 & 19 & 2 & 6 & 10 & 46 \\
\hline & Q3 & 8 & 16 & 2 & 7 & 9 & 42 \\
\hline & Q4 & 5 & 15 & 3 & 8 & 9 & 40 \\
\hline SO & Q1 & 5 & 12 & 3 & 7 & 10 & 37 \\
\hline & Q2 & 8 & 17 & 5 & 2 & 4 & 36 \\
\hline & Q3 & 6 & 15 & 2 & 7 & 10 & 40 \\
\hline & Q4 & 2 & 10 & 2 & 3 & 9 & 26 \\
\hline ALL & Q1 & 18 & 47 & 13 & 21 & 31 & 130 \\
\hline & Q2 & 27 & 51 & 9 & 14 & 25 & 126 \\
\hline & Q3 & 19 & 42 & 7 & 18 & 27 & 113 \\
\hline & Q4 & 8 & 30 & 6 & 13 & 22 & 79 \\
\hline & TOTALS & $72(30 \%)$ & 170 & 35 & 66 & $105(23 \%)$ & 448 \\
\hline
\end{tabular}

When analyzing the responses according to quartile breakdown, there was not much difference between the different grades or quartiles. The only noticeable difference occurred with students grouped in the second quartile. Twenty-one percent $(n=27)$ of these students responded "strongly agree" to this question, while the average of the other three quartiles was only 14 percent.

Question 4: My grades for this nine weeks this year were generally than in the past.
A -- better
B -- worse
C-- about the same 
Table 12 shows the responses to this question from the students grouped according to their quartile and grade.

Table 12

SUMMARY OF STUDENT RESPONSES BY QUARTILE AND AS A WHOLE TO QUESTION 4 OF THE ATTITUDE QUESTIONNAIRE

\begin{tabular}{|l|l|c|c|c|c|}
\hline & & $\begin{array}{c}\mathrm{A} \\
\text { Better }\end{array}$ & $\begin{array}{c}\mathrm{B} \\
\text { Worse }\end{array}$ & $\begin{array}{c}\text { C } \\
\text { Same }\end{array}$ & TOTALS \\
\hline SR & Q1 & 8 & 4 & 35 & 47 \\
\hline & Q2 & 24 & 5 & 15 & 44 \\
\hline & Q3 & 16 & 2 & 13 & 31 \\
\hline & Q4 & 3 & 2 & 8 & 13 \\
\hline JR & Q1 & 9 & 5 & 32 & 46 \\
\hline & Q2 & 24 & 4 & 18 & 46 \\
\hline & Q3 & 23 & 5 & 14 & 42 \\
\hline & Q4 & 14 & 3 & 23 & 40 \\
\hline SO & Q1 & 8 & 3 & 26 & 37 \\
\hline & Q2 & 20 & 3 & 13 & 36 \\
\hline & Q3 & 17 & 5 & 18 & 40 \\
\hline & Q4 & 12 & 5 & 9 & 26 \\
\hline ALL & Q1 & 25 & 12 & 93 & 130 \\
\hline & Q2 & 68 & 12 & 46 & 126 \\
\hline & Q3 & 56 & 12 & 45 & 113 \\
\hline & Q4 & 29 & 10 & 40 & 79 \\
\hline & TOTALS & $178(39 \%)$ & $46(11 \%)$ & $224(50 \%)$ & 448 \\
\hline
\end{tabular}

during the block schedule year, while only 11 percent $(n=46)$ of the students felt their grades were better during the traditional schedule year. From the total student sample, 50 percent $(n=224)$ of the students responded that they saw no change between the two years. Thirty-nine percent $(n=178)$ of the students felt their grades were better The students grouped in the second and third quartile responded similarly to this question, and their responses were quite different than those of the students in the first and fourth quartile. Fifty-four percent $(n=68)$ of the students in the second quartile and 50 percent $(n=56)$ of the students in the third quartile felt that their grades were better during the 
block year. In contrast, only 19 percent $(n=25)$ of the students in the first quartile and 37 percent $(n=29)$ of the students in the fourth quartile felt that this was the case.

Another strong difference between the quartiles occurred when comparing their responses to this question. Students in the first quartile had the highest percentage of responses that there was no difference in their grades between the two years $(72 \%$ or $n=93$ ). The average of the other three quartiles was only 41 percent.

Question 5 I am being assigned

$$
A \text {-- more } \quad B \text {-- less } \quad C \text {-- about the same }
$$

Table 13 shows the responses to this question from the students grouped according to their quartile and grade. From the total student sample, 29 percent $(n=132)$ of the students responded that they saw no change between the two years. Twenty percent $(n=90)$ of the students felt they had more homework during the block schedule year, while the majority of the students $(51 \%$ or $n=226)$ felt they had less homework during the block schedule year. The breakdown of responses between the grades and quartile were all very similar to this question. 
Table 13

SUMMARY OF STUDENT RESPONSES BY QUARTILE AND AS A WHOLE TO QUESTION 5 OF THE ATTITUDE QUESTIONNAIRE

\begin{tabular}{|l|l|c|c|c|c|}
\hline & & $\begin{array}{c}\text { A } \\
\text { More }\end{array}$ & $\begin{array}{c}\text { B } \\
\text { Less }\end{array}$ & $\begin{array}{c}\text { C } \\
\text { About the } \\
\text { Same }\end{array}$ & TOTALS \\
\hline & Q1 & 9 & 24 & 14 & 47 \\
\hline & Q2 & 8 & 24 & 12 & 44 \\
\hline & Q3 & 5 & 18 & 8 & 31 \\
\hline JR & Q4 & 3 & 7 & 3 & 13 \\
\hline & Q1 & 9 & 25 & 12 & 46 \\
\hline & Q2 & 5 & 23 & 18 & 46 \\
\hline & Q3 & 6 & 18 & 18 & 42 \\
\hline SO & Q4 & 9 & 20 & 11 & 40 \\
\hline & Q1 & 9 & 18 & 10 & 37 \\
\hline & Q2 & 8 & 16 & 12 & 36 \\
\hline & Q3 & 10 & 20 & 10 & 40 \\
\hline ALL & Q4 & 9 & 13 & 4 & 26 \\
\hline & Q1 & 27 & 67 & 36 & 130 \\
\hline & Q2 & 21 & 63 & 42 & 126 \\
\hline & Q3 & 21 & 56 & 36 & 113 \\
\hline & Q4 & 21 & 40 & 18 & 79 \\
\hline & TOTALS & $90(20 \%$ & $226(51 \%)$ & $132(29 \%)$ & 448 \\
\hline
\end{tabular}

Question 6: I am experiencing confusion about homework assignments this year.

$$
\text { A -- more } \quad B \text {-- less } \quad C \text {-- approximately the same }
$$

Table 14 shows the responses to this question from the students grouped according to their quartile and grade. From the total student sample, 38 percent $(n=170)$ of the students responded that they saw no change between the two years. Forty-six percent $(n=208)$ of the students felt they experienced less 
Table 14

SUMMARY OF STUDENT RESPONSES BY QUARTILE AND AS A WHOLE TO QUESTION 6 OF THE ATTITUDE QUESTIONNAIRE

\begin{tabular}{|l|l|c|c|c|c|}
\hline & & $\begin{array}{c}\text { A } \\
\text { More }\end{array}$ & $\begin{array}{c}\text { B } \\
\text { Less }\end{array}$ & $\begin{array}{c}\text { C } \\
\text { Approximately } \\
\text { the Same }\end{array}$ & TOTALS \\
\hline SR & Q1 & 7 & 20 & 20 & 47 \\
\hline & Q2 & 6 & 22 & 16 & 44 \\
\hline & Q3 & 5 & 16 & 10 & 31 \\
\hline & Q4 & 9 & 1 & 3 & 13 \\
\hline & Q1 & 4 & 21 & 21 & 46 \\
\hline & Q2 & 3 & 27 & 16 & 46 \\
\hline & Q3 & 6 & 20 & 16 & 42 \\
\hline & Q4 & 9 & 17 & 14 & 40 \\
\hline & Q1 & 5 & 10 & 22 & 37 \\
\hline & Q2 & 2 & 24 & 10 & 36 \\
\hline & Q3 & 5 & 18 & 17 & 40 \\
\hline ALL & Q4 & 9 & 12 & 5 & 26 \\
\hline & Q1 & 16 & 51 & 63 & 130 \\
\hline & Q2 & 11 & 73 & 42 & 126 \\
\hline & Q3 & 16 & 54 & 43 & 113 \\
\hline & Q4 & 27 & 30 & 22 & 79 \\
\hline & TOTALS & $70(16 \%)$ & $208(46 \%)$ & $170(38 \%)$ & 448 \\
\hline
\end{tabular}

confusion during the block schedule year, while only 16 percent $(n=70)$ of the students felt they experienced more confusion during the block schedule year.

The students grouped in the fourth quartile reported the largest percentage of responses that they experienced more difficulty during the block schedule year. Thirtyfive percent $(n=27)$ of these students reported experiencing more difficulty in the fourth quartile while the average percentage of the other quartiles for this response was only 12 percent.

Another noticeable difference between the quartiles occurred when comparing their responses to this question. Students in the first quartile had the highest percentage of responses that there was no difference in the amount of confusion they 
were experiencing between the two years $(48 \%$ or $n=63)$. The average of the other three quartiles was only 34 percent.

Question 7 I am finding it to complete my homework

assignments this year.
A -- easier
B -- harder
C -- about the same

Table 15 shows the responses to this question from the students grouped according to their quartile and grade.

\section{Table 15}

SUMMARY OF STUDENT RESPONSES BY QUARTILE AND AS A WHOLE TO QUESTION 7 OF THE ATTITUDE QUESTIONNAIRE

\begin{tabular}{|l|l|c|c|c|c|}
\hline & & $\begin{array}{c}\text { A } \\
\text { Easier }\end{array}$ & $\begin{array}{c}\text { B } \\
\text { Harder }\end{array}$ & $\begin{array}{c}\text { C } \\
\text { About the } \\
\text { Same }\end{array}$ & TOTALS \\
\hline SR & Q1 & 15 & 4 & 28 & 47 \\
\hline & Q2 & 20 & 5 & 19 & 44 \\
\hline & Q3 & 12 & 2 & 17 & 31 \\
\hline & Q4 & 4 & 2 & 7 & 13 \\
\hline JR & Q1 & 14 & 5 & 27 & 46 \\
\hline & Q2 & 23 & 3 & 20 & 46 \\
\hline & Q3 & 20 & 4 & 18 & 42 \\
\hline & Q4 & 14 & 6 & 20 & 40 \\
\hline SO & Q1 & 9 & 2 & 26 & 37 \\
\hline & Q2 & 19 & 2 & 15 & 36 \\
\hline & Q3 & 17 & 5 & 18 & 40 \\
\hline & Q4 & 11 & 5 & 10 & 26 \\
\hline & Q1 & 38 & 11 & 81 & 130 \\
\hline & Q2 & 62 & 10 & 54 & 126 \\
\hline & Q3 & 49 & 11 & 53 & 113 \\
\hline & Q4 & 29 & 13 & 37 & 79 \\
\hline & TOTALS & $178(48 \%)$ & $45(10 \%)$ & $225(50 \%)$ & 448 \\
\hline
\end{tabular}

From the total student sample, 50 percent $(n=225)$ of the students responded that the level of difficulty of homework was about the same between the two years. Forty percent $(n=178)$ of the students felt that the homework was easier during the block 
schedule year, while only 10 percent $(n=45)$ felt that the homework was more difficult during the block schedule year.

When analyzing the responses according to quartile breakdown there was not much difference between the grades or quartiles. One noticeable difference occurred with students grouped in the first quartile. Sixty-two percent $(n=81)$ of these students responded that there was no difference in the level of difficulty of their homework between the two years. The average of the other three quartiles for this response was only 44 percent.

The quartile analysis also revealed a wide range in students responding that they felt the homework was easier during the block schedule year. The second quartile scored 48 percent $(n=62)$ for this response, the third quartile 43 percent $(n=49)$, the fourth quartile 37 percent $(n=29)$ and the first quartile 29 percent $(n=38)$.

Question 8 I am alert and attentive in class this year.

$$
\begin{aligned}
& \text { A -- more } \\
& \text { B -- less } \\
& C \text {-- about the same as last year }
\end{aligned}
$$

Table 16 shows the responses to this question from the students grouped according to their quartile and grade. Thirty-two percent $(n=142)$ of the students 
Table 16

SUMMARY OF STUDENT RESPONSES BY QUARTILE AND AS A WHOLE TO QUESTION 8 OF THE ATTITUDE QUESTIONNAIRE

\begin{tabular}{|l|l|c|c|c|c|}
\hline & & $\begin{array}{c}\text { A } \\
\text { More }\end{array}$ & $\begin{array}{c}\text { B } \\
\text { Less }\end{array}$ & $\begin{array}{c}\text { C } \\
\text { About the } \\
\text { Same as Last } \\
\text { Year }\end{array}$ & TOTALS \\
\hline SR & Q1 & 12 & 20 & 15 & 47 \\
\hline & Q2 & 11 & 19 & 14 & 44 \\
\hline & Q3 & 7 & 14 & 10 & 31 \\
\hline & Q4 & 2 & 8 & 3 & 13 \\
\hline JR & Q1 & 12 & 20 & 14 & 46 \\
\hline & Q2 & 12 & 19 & 15 & 46 \\
\hline & Q3 & 10 & 19 & 13 & 42 \\
\hline & Q4 & 10 & 17 & 13 & 40 \\
\hline SO & Q1 & 10 & 15 & 12 & 37 \\
\hline & Q2 & 10 & 15 & 11 & 36 \\
\hline & Q3 & 9 & 16 & 15 & 40 \\
\hline & Q4 & 7 & 12 & 7 & 26 \\
\hline ALL & Q1 & 34 & 55 & 41 & 130 \\
\hline & Q2 & 33 & 53 & 40 & 126 \\
\hline & Q3 & 26 & 49 & 38 & 113 \\
\hline & Q4 & 19 & 37 & 23 & 79 \\
\hline & TOTALS & $112(25 \%)$ & $194(43 \%)$ & $142(32 \%)$ & 448 \\
\hline
\end{tabular}

responded that they saw no change between the two years. Twenty-five percent $(n=112)$ of the students felt they were more attentive during the block schedule year, while 43 percent $(n=194)$ felt they were less attentive during the block schedule year. The breakdown of responses between the grades and quartile were all very similar to this question.

\section{Question 9: I like learning better in ninety-minute blocks of time.}

$$
\begin{aligned}
& \text { A -- strongly agree } \\
& \text { B -- agree } \\
& \text { C -- disagree } \\
& \text { D -- strongly disagree }
\end{aligned}
$$




\section{E -- length of class period makes no difference}

Table 17 shows the responses to this question from the students grouped according to their quartile and grade.

\section{Table 17}

SUMMARY OF STUDENT RESPONSES BY QUARTILE AND AS A WHOLE TO QUESTION 9 OF THE ATTITUDE QUESTIONNAIRE

\begin{tabular}{|l|l|c|c|c|c|c|c|}
\hline & & $\begin{array}{c}\text { A } \\
\text { Strongly } \\
\text { Agree }\end{array}$ & $\begin{array}{c}\text { B } \\
\text { Agree }\end{array}$ & $\begin{array}{c}\text { C } \\
\text { Disagree }\end{array}$ & $\begin{array}{c}\text { D } \\
\text { Strongly } \\
\text { Disagree }\end{array}$ & $\begin{array}{c}\text { E } \\
\text { Makes No } \\
\text { Difference }\end{array}$ & TOTALS \\
\hline SR & Q1 & 6 & 15 & 11 & 1 & 14 & 47 \\
\hline & Q2 & 12 & 14 & 7 & 2 & 9 & 44 \\
\hline & Q3 & 4 & 13 & 5 & 1 & 8 & 31 \\
\hline & Q4 & 0 & 2 & 5 & 4 & 2 & 13 \\
\hline & Q1 & 6 & 14 & 6 & 4 & 16 & 46 \\
\hline & Q2 & 5 & 22 & 7 & 2 & 10 & 46 \\
\hline & Q3 & 5 & 19 & 6 & 3 & 9 & 42 \\
\hline SO & Q4 & 2 & 13 & 10 & 6 & 9 & 40 \\
\hline & Q1 & 5 & 14 & 6 & 2 & 10 & 37 \\
\hline & Q2 & 6 & 14 & 3 & 3 & 10 & 36 \\
\hline & Q3 & 4 & 21 & 4 & 1 & 10 & 40 \\
\hline & Q4 & 2 & 8 & 8 & 4 & 4 & 26 \\
\hline & Q1 & 17 & 43 & 23 & 7 & 40 & 130 \\
\hline & Q2 & 23 & 50 & 17 & 7 & 29 & 126 \\
\hline & Q3 & 13 & 53 & 15 & 5 & 27 & 113 \\
\hline & Q4 & 4 & 23 & 23 & 14 & 15 & 79 \\
\hline & TOTALS & $57(25 \%)$ & 169 & 78 & 33 & $111(25 \%)$ & 448 \\
\hline
\end{tabular}

From the total student sample, 25 percent $(n=111)$ of the students responded that they saw no change between the two years. The majority of the students responded favorably toward the block schedule $(50 \%$ or $n=226)$, and of these students 25 percent $(\mathrm{n}=57)$ strongly agreed that the block schedule had a positive impact on their understanding of their lessons. Twenty-five percent $(n=111)$ of the students felt they understood lessons better in the traditional schedule. 
The students grouped in the second and third quartile responded similarly to this question, and their responses were quite different than those of the students in the first and fourth quartile. Fifty-eight percent $(n=73)$ of the students in the second quartile and 58 percent $(n=66)$ of the students in the third quartile liked learning better in 90 minute blocks of time. In contrast, only 46 percent $(n=60)$ of the students in the first quartile and 34 percent $(n=27)$ of the students in the fourth quartile felt that this was the case.

Another difference between the quartiles is seen when comparing the students' responses to this question. Students in the first quartile had the highest percentage of responses that felt that length of period made no difference in their learning $(31 \%$ or $\mathrm{n}=40$ ). The average of the other three quartiles was only 22 percent.

\section{Question 10: The option of taking an eighth course on the four-four plan is for me.}

\section{A -- an advantage \\ B -- a disadvantage \\ C -- does not matter to me}

Table 18 shows the responses to this question from the students grouped according to their quartile and grade. Twenty-five percent $(n=114)$ of the students responded that the added course made no difference to them. Eight percent $(n=37)$ of the students felt this option was a disadvantage, while an overwhelming majority of the students $(66 \%$ or $\mathrm{n}=297$ ) felt that the added course was an advantage. 
Table 18

SUMMARY OF STUDENT RESPONSES BY QUARTILE AND AS A WHOLE TO QUESTION 10 OF THE ATTITUDE QUESTIONNAIRE

\begin{tabular}{|l|l|c|c|c|c|}
\hline & & $\begin{array}{c}\text { A } \\
\text { An Advantage }\end{array}$ & $\begin{array}{c}\text { B } \\
\text { A } \\
\text { Disadvantage }\end{array}$ & $\begin{array}{c}\text { C } \\
\text { Does Not } \\
\text { Matter }\end{array}$ & TOTALS \\
\hline SR & Q1 & 39 & 1 & 7 & 47 \\
\hline & Q2 & 35 & 0 & 9 & 44 \\
\hline & Q3 & 20 & 3 & 8 & 31 \\
\hline & Q4 & 4 & 5 & 4 & 13 \\
\hline JR & Q1 & 37 & 2 & 7 & 46 \\
\hline & Q2 & 40 & 1 & 5 & 46 \\
\hline & Q3 & 28 & 5 & 9 & 42 \\
\hline & Q4 & 21 & 5 & 14 & 40 \\
\hline SO & Q1 & 28 & 2 & 7 & 37 \\
\hline & Q2 & 18 & 3 & 15 & 36 \\
\hline & Q3 & 19 & 4 & 17 & 40 \\
\hline & Q4 & 8 & 6 & 12 & 26 \\
\hline & Q1 & 104 & 5 & 21 & 130 \\
\hline & Q2 & 93 & 4 & 29 & 126 \\
\hline & Q3 & 67 & 12 & 34 & 113 \\
\hline & Q4 & 33 & 16 & 30 & 79 \\
\hline & TOTALS & $297(66 \%)$ & $37(8 \%)$ & $114(25 \%)$ & 448 \\
\hline
\end{tabular}

The analysis of the quartiles revealed that the higher the student quartile, the more the student saw taking the additional courses as a benefit, and likewise the lower the student quartile the more likely the students were to see the additional course as a disadvantage.

Question 11: I seem to be learning this year.
A -- more
$B$-- less
C -- About the same

Table 19 shows the responses to this question from the students grouped according to their quartile and grade. 
Table 19

SUMMARY OF STUDENT RESPONSES BY QUARTILE AND AS A WHOLE TO QUESTION 11 OF THE ATTITUDE QUESTIONNAIRE

\begin{tabular}{|l|l|c|c|c|c|}
\hline & & $\begin{array}{c}\text { A } \\
\text { More }\end{array}$ & $\begin{array}{c}\text { B } \\
\text { Less }\end{array}$ & $\begin{array}{c}\text { C } \\
\text { About the } \\
\text { Same }\end{array}$ & TOTALS \\
\hline SR & Q1 & 21 & 7 & 19 & 47 \\
\hline & Q2 & 26 & 4 & 14 & 44 \\
\hline & Q3 & 17 & 5 & 9 & 31 \\
\hline & Q4 & 2 & 8 & 3 & 13 \\
\hline JR & Q1 & 21 & 4 & 21 & 46 \\
\hline & Q2 & 28 & 3 & 15 & 46 \\
\hline & Q3 & 23 & 6 & 13 & 42 \\
\hline & Q4 & 15 & 10 & 15 & 40 \\
\hline SO & Q1 & 15 & 4 & 18 & 37 \\
\hline & Q2 & 23 & 2 & 11 & 36 \\
\hline & Q3 & 20 & 5 & 15 & 40 \\
\hline & Q4 & 13 & 8 & 5 & 26 \\
\hline ALL & Q1 & 57 & 15 & 58 & 130 \\
\hline & Q2 & 77 & 9 & 40 & 126 \\
\hline & Q3 & 60 & 16 & 37 & 113 \\
\hline & Q4 & 30 & 26 & 23 & 79 \\
\hline & TOTALS & $224(50 \%)$ & $66(15 \%)$ & $158(35 \%)$ & 448 \\
\hline
\end{tabular}

From the total student sample, 35 percent $(n=158)$ of the students responded that they saw no change between the two years. The majority of the students responded that they seemed to be learning more during the block schedule year $(n=224$ or $50 \%)$. Fifteen percent $(n=66)$ of the students felt they were learning less under the block schedule year.

The students grouped in the second and third quartile responded similarly to this question, and their responses were quite different than those of the students in the first and fourth quartile. Sixty-one percent $(n=77)$ of the students in the second quartile and 53 percent $(n=60)$ of the students in the third quartile felt that they were learning more during the block schedule year. In contrast, only 44 percent $(n=57)$ of the students in 
the first quartile and 38 percent $(n=30)$ of the students in the fourth quartile felt that this was the case.

Another difference between the quartiles is seen when comparing the students' responses to this question. Students in the first quartile had the highest percentage of responses that felt that their learning was about the same for both years ( $45 \%$ or $n=58)$. The average of the other three quartiles was only 31 percent.

Question 12: How many of your teachers lecture too much:

$$
\begin{aligned}
& A \text {-- four; } \quad B \text {-- three } \quad C \text {-- two } \\
& D \text {-- one; } \quad E \text {-- none }
\end{aligned}
$$

Table 20 shows the responses to this question from the students grouped according to their quartile and grade. From the total student sample, the majority of the students ( $37 \%$ or $n=165)$ felt that only one of their teachers lectured too much. Twentynine percent $(n=128)$ of the students responded that two of their teachers lectured too much, while 14 percent $(n=64)$ felt that none of their teachers did. Thirteen percent $(n=60)$ of the students felt that three teachers lectured too much while only 35 percent $(n=31)$ of the students responded that four of their teachers lectured too much. The students grouped in the fourth quartile reported the largest percentage of responses that four teachers lectured too much. This quartile contributed 45 percent $(n=14)$ of these responses. The response that was most frequently given to this question was that one teacher lectured too much. The first quartile students comprised 35 percent of these responses. 
Table 20

SUMMARY OF STUDENT RESPONSES BY QUARTILE AND AS A WHOLE TO QUESTION 12 OF THE

\section{ATTITUDE QUESTIONNAIRE}

\begin{tabular}{|l|l|c|c|c|c|c|c|}
\hline & & $\begin{array}{c}\text { A } \\
\text { Four }\end{array}$ & $\begin{array}{c}\text { B } \\
\text { Three }\end{array}$ & $\begin{array}{c}\text { C } \\
\text { Two }\end{array}$ & $\begin{array}{c}\text { D } \\
\text { One }\end{array}$ & $\begin{array}{c}\text { E } \\
\text { None }\end{array}$ & TOTALS \\
\hline SR & Q1 & 1 & 6 & 14 & 19 & 7 & 47 \\
\hline & Q2 & 2 & 12 & 12 & 14 & 4 & 44 \\
\hline & Q3 & 1 & 4 & 8 & 10 & 8 & 31 \\
\hline & Q4 & 4 & 2 & 3 & 2 & 2 & 13 \\
\hline JR & Q1 & 2 & 6 & 12 & 21 & 5 & 46 \\
\hline & Q2 & 2 & 5 & 18 & 17 & 4 & 46 \\
\hline & Q3 & 3 & 4 & 16 & 13 & 6 & 42 \\
\hline & Q4 & 6 & 2 & 11 & 15 & 6 & 40 \\
\hline SO & Q1 & 2 & 4 & 8 & 18 & 5 & 37 \\
\hline & Q2 & 3 & 6 & 12 & 11 & 4 & 36 \\
\hline & Q3 & 1 & 4 & 10 & 20 & 5 & 40 \\
\hline & Q4 & 4 & 5 & 4 & 5 & 8 & 26 \\
\hline ALL & Q1 & 5 & 16 & 34 & 58 & 17 & 130 \\
\hline & Q2 & 7 & 23 & 42 & 42 & 12 & 126 \\
\hline & Q3 & 5 & 12 & 34 & 43 & 19 & 113 \\
\hline & Q4 & 14 & 9 & 18 & 22 & 16 & 79 \\
\hline & TOTALS & $31(35 \%)$ & $60(13 \%)$ & $128(29 \%)$ & $165(37 \%)$ & $64(14 \%)$ & 448 \\
\hline
\end{tabular}

Question 13: My teachers are providing variety in instructional

activities than they did in last year.

$$
\begin{aligned}
& \text { A -- more } \\
& \text { B -- less } \\
& \text { C -- about the same as last year }
\end{aligned}
$$

Table 21 shows the responses to this question from the students grouped according to their quartile and grade. 


\section{Table 21}

SUMMARY OF STUDENT RESPONSES BY QUARTILE AND AS A WHOLE TO QUESTION 13 OF THE

\section{ATTITUDE QUESTIONNAIRE}

\begin{tabular}{|l|l|c|c|c|c|}
\hline & & $\begin{array}{c}\text { A } \\
\text { More }\end{array}$ & $\begin{array}{c}\text { B } \\
\text { Less }\end{array}$ & $\begin{array}{c}\text { C } \\
\text { About the } \\
\text { Same as Last } \\
\text { Year }\end{array}$ & TOTALS \\
\hline SR & Q1 & 20 & 11 & 16 & 47 \\
\hline & Q2 & 22 & 7 & 15 & 44 \\
\hline & Q3 & 16 & 5 & 10 & 31 \\
\hline & Q4 & 5 & 6 & 2 & 13 \\
\hline JR & Q1 & 20 & 8 & 18 & 46 \\
\hline & Q2 & 17 & 7 & 22 & 46 \\
\hline & Q3 & 21 & 6 & 15 & 42 \\
\hline & Q4 & 14 & 13 & 13 & 40 \\
\hline SO & Q1 & 15 & 6 & 16 & 37 \\
\hline & Q2 & 19 & 3 & 14 & 36 \\
\hline & Q3 & 16 & 4 & 20 & 40 \\
\hline & Q4 & 12 & 8 & 6 & 26 \\
\hline ALL & Q1 & 55 & 25 & 50 & 130 \\
\hline & Q2 & 58 & 17 & 51 & 126 \\
\hline & Q3 & 53 & 15 & 45 & 113 \\
\hline & Q4 & 31 & 27 & 21 & 79 \\
\hline & TOTALS & $197(44 \%)$ & $84(19 \%)$ & $167(37 \%)$ & 448 \\
\hline
\end{tabular}

From the total student sample, 37 percent $(n=167)$ of the students responded that they saw no change between the two years. Forty-four percent $(n=197)$ of the students responded that their teachers were providing more variation in instruction during the block schedule year, while only 19 percent $(\mathrm{n}=84)$ of the students responded that their teachers were providing less variation in instruction during the block schedule year.

The analysis of each quartile revealed that the fourth quartile was the only quartile where the span between those students who felt that the teachers were providing more varied instruction and those who did not was minimal. There was only 
a four response difference for the students in the fourth quartile, while the average difference in response for the other three quartiles was 36.

Question 14: Compare student behavior in the classroom under the two systems.

A -- This year there is less disruptive/inappropriate behavior. B -- This year there is more disruptive/inappropriate behavior. C -- Things are about the same as last year.

Table 22 shows the responses to this question from the students grouped according to their quartile and grade. Twenty-nine percent $(n=131)$ of the students responded that there was more disruptive behavior in the classroom during the block schedule year, while 18 percent $(n=82)$ of the students responded that there was less disruptive behavior during the block schedule year. The quartile analysis revealed no noticeable differences in responses between the grades or quartiles.

Table 22

SUMMARY OF STUDENT RESPONSES BY QUARTILE AND AS A WHOLE TO QUESTION 14 OF THE ATTITUDE QUESTIONNAIRE

\begin{tabular}{|l|l|c|c|c|c|}
\hline & & $\begin{array}{c}\text { A } \\
\text { Less } \\
\text { Disruptive/ } \\
\text { Inappropriate } \\
\text { Behavior }\end{array}$ & $\begin{array}{c}\text { B } \\
\text { More } \\
\text { Disruptive/ } \\
\text { Inappropriate } \\
\text { Behavior }\end{array}$ & $\begin{array}{c}\text { C } \\
\text { About the } \\
\text { Same as Last } \\
\text { Year }\end{array}$ & TOTALS \\
\hline SR & Q1 & 10 & 11 & 26 & 47 \\
\hline & Q2 & 9 & 12 & 23 & 44 \\
\hline & Q3 & 5 & 6 & 20 & 31 \\
\hline & Q4 & 2 & 2 & 9 & 13 \\
\hline JR & Q1 & 9 & 14 & 23 & 46 \\
\hline & Q2 & 4 & 18 & 24 & 46 \\
\hline & Q3 & 6 & 16 & 20 & 42 \\
\hline & Q4 & 10 & 11 & 19 & 40 \\
\hline
\end{tabular}




\begin{tabular}{|l|l|c|c|c|c|}
\hline SO & Q1 & 7 & 11 & 19 & 37 \\
\hline & Q2 & 7 & 12 & 17 & 36 \\
\hline & Q3 & 9 & 10 & 21 & 40 \\
\hline & Q4 & 4 & 8 & 14 & 26 \\
\hline ALL & Q1 & 26 & 36 & 68 & 130 \\
\hline & Q2 & 20 & 42 & 64 & 126 \\
\hline & Q3 & 20 & 32 & 61 & 113 \\
\hline & Q4 & 16 & 21 & 42 & 79 \\
\hline & TOTALS & $82(18 \%)$ & $131(29 \%)$ & $235(52 \%)$ & 448 \\
\hline
\end{tabular}

\section{Question 15: I find that the general behavior of students around the}

school (corridors, commons, class changes, etc.) is

$$
\begin{aligned}
& \text { A -- better than last year } \\
& B \text {-- worse than last year } \\
& \text { C -- about the same as last year }
\end{aligned}
$$

Table 23 shows the responses to this question from the students grouped according to their quartile and grade.

\section{Table 23}

SUMMARY OF STUDENT RESPONSES BY QUARTILE AND AS A WHOLE TO QUESTION 15 OF THE ATTITUDE QUESTIONNAIRE

\begin{tabular}{|l|l|c|c|c|c|}
\hline & & $\begin{array}{c}\text { A } \\
\text { Better }\end{array}$ & $\begin{array}{c}\text { B } \\
\text { Worse }\end{array}$ & $\begin{array}{c}\text { C } \\
\text { Same as Last } \\
\text { Year }\end{array}$ & TOTALS \\
\hline SR & Q1 & 8 & 7 & 32 & 47 \\
\hline & Q2 & 12 & 5 & 27 & 44 \\
\hline & Q3 & 8 & 5 & 18 & 31 \\
\hline & Q4 & 2 & 5 & 6 & 13 \\
\hline JR & Q1 & 11 & 6 & 29 & 46 \\
\hline & Q2 & 11 & 7 & 28 & 46 \\
\hline & Q3 & 11 & 6 & 25 & 42 \\
\hline & Q4 & 7 & 10 & 23 & 40 \\
\hline SO & Q1 & 8 & 4 & 25 & 37 \\
\hline & Q2 & 12 & 2 & 22 & 36 \\
\hline & Q3 & 13 & 5 & 22 & 40 \\
\hline & Q4 & 6 & 8 & 12 & 26 \\
\hline ALL & Q1 & 27 & 17 & 86 & 130 \\
\hline
\end{tabular}




\begin{tabular}{|l|l|c|c|c|c|}
\hline & Q2 & 35 & 14 & 77 & 126 \\
\hline & Q3 & 32 & 16 & 65 & 113 \\
\hline & Q4 & 15 & 23 & 41 & 79 \\
\hline & TOTALS & $109(24 \%)$ & $70(16 \%)$ & $269(60 \%)$ & 448 \\
\hline
\end{tabular}

From the total student sample, 60 percent $(n=269)$ of the students responded that they saw no change in student behavior around the school between the two systems. Twenty-four percent $(n=109)$ of the students responded that the general behavior around the school was better during the block schedule year, while 16 percent $(n=70)$ of the students responded that the general behavior around the school was worse during the block schedule year.

The quartile analysis revealed noticeable differences in responses between how the second and third quartile students viewed general student behavior as opposed to the views of the first and fourth quartile students. Twenty-eight percent $(n=35)$ of second quartile students and 28 percent $(n=32)$ of third quartile students felt that the general behavior in the school was better during the block schedule year, while only 21 percent of first quartile students and 18 percent of fourth quartile students felt that this was the case. In fact, the fourth quartile students actually had a higher percentage of students who thought that the general behavior of students during the block schedule year was worse $(29 \%$ or $n=23)$ than those who thought that it was better $(19 \%$ or $n=15)$ during the block schedule year. This was the only quartile where this was the case.

Question 16: My teachers have been in more contact with my parents this year.
A -- strongly agree; $\quad$ B -- agree;
C -- disagree; $\quad$ D -- strongly disagree;
E -- no difference between this year and last year 


\section{year and last year}

Table 24 shows the responses to this question from the students grouped according to their quartile and grade. From the total student sample, 42 percent $(n=186)$ of the students responded that they saw no change between the two years. Twelve percent $(n=53)$ of the students felt that their teachers had been in

\section{Table 24}

SUMMARY OF STUDENT RESPONSES BY QUARTILE AND AS A WHOLE TO QUESTION 16 OF THE

\section{ATTITUDE QUESTIONNAIRE}

\begin{tabular}{|l|l|c|c|c|c|c|c|}
\hline & & $\begin{array}{c}\text { A } \\
\text { Strongly } \\
\text { Agree }\end{array}$ & $\begin{array}{c}\text { B } \\
\text { Agree }\end{array}$ & $\begin{array}{c}\text { C } \\
\text { Disagree }\end{array}$ & $\begin{array}{c}\text { D } \\
\text { Strongly } \\
\text { Disagree }\end{array}$ & $\begin{array}{c}\text { E } \\
\text { No } \\
\text { Difference } \\
\text { Between } \\
\text { This Year \& } \\
\text { Last Year }\end{array}$ & TOTALS \\
\hline SR & Q1 & 1 & 3 & 7 & 13 & 23 & 47 \\
\hline & Q2 & 2 & 2 & 6 & 12 & 22 & 44 \\
\hline & Q3 & 1 & 1 & 7 & 6 & 16 & 31 \\
\hline & Q4 & 0 & 2 & 4 & 2 & 5 & 13 \\
\hline JR & Q1 & 2 & 2 & 8 & 14 & 20 & 46 \\
\hline & Q2 & 2 & 2 & 7 & 18 & 17 & 46 \\
\hline & Q3 & 1 & 3 & 7 & 16 & 15 & 42 \\
\hline & Q4 & 2 & 6 & 10 & 11 & 11 & 40 \\
\hline SO & Q1 & 2 & 3 & 6 & 11 & 15 & 37 \\
\hline & Q2 & 4 & 4 & 8 & 8 & 12 & 36 \\
\hline & Q3 & 3 & 3 & 3 & 12 & 19 & 40 \\
\hline & Q4 & 1 & 1 & 5 & 8 & 11 & 26 \\
\hline ALL & Q1 & 5 & 8 & 21 & 38 & 58 & 130 \\
\hline & Q2 & 8 & 8 & 21 & 38 & 51 & 126 \\
\hline & Q3 & 5 & 7 & 17 & 34 & 50 & 113 \\
\hline & Q4 & 3 & 9 & 19 & 21 & 27 & 79 \\
\hline & TOTALS & 21 & 32 & 78 & $131(63 \%)$ & $186(42 \%)$ & 448 \\
\hline
\end{tabular}

more contact during the block schedule year with their parents, while 47 percent $(n=209)$ of the students felt that their teachers had been in less contact during the block schedule year. Sixty-three percent $(n=131)$ of the students who felt that their teachers 
had been in less contact with their teachers strongly believed so. The breakdown of responses between the grades and quartile were all very similar to this question. 
Question 17: My teachers seem to know me better this year.
A -- strongly agree;
B -- agree;
C -- disagree;
D -- strongly disagree
$E$-- No difference between this year and last year

Table 25 shows the responses to this question from the students grouped according to their quartile and grade.

Table 25

SUMMARY OF STUDENT RESPONSES BY QUARTILE AND AS A WHOLE TO QUESTION 17 OF THE ATTITUDE QUESTIONNAIRE

\begin{tabular}{|l|l|c|c|c|c|c|c|}
\hline & & $\begin{array}{c}\text { A } \\
\text { Strongly } \\
\text { Agree }\end{array}$ & $\begin{array}{c}\text { B } \\
\text { Agree }\end{array}$ & $\begin{array}{c}\text { C } \\
\text { Disagree }\end{array}$ & $\begin{array}{c}\text { D } \\
\text { Strongly } \\
\text { Disagree } \\
\text { Difference } \\
\text { Between } \\
\text { This Year } \\
\text { and Last } \\
\text { Year }\end{array}$ & \\
\hline SR & Q1 & 5 & 21 & 9 & 3 & 9 & 47 \\
\hline & Q2 & 7 & 24 & 3 & 2 & 8 & 44 \\
\hline & Q3 & 6 & 15 & 4 & 1 & 5 & 31 \\
\hline & Q4 & 1 & 4 & 3 & 2 & 3 & 13 \\
\hline JR & Q1 & 4 & 20 & 8 & 2 & 12 & 46 \\
\hline & Q2 & 9 & 17 & 7 & 2 & 11 & 46 \\
\hline & Q3 & 12 & 16 & 5 & 3 & 6 & 42 \\
\hline & Q4 & 3 & 13 & 13 & 4 & 7 & 40 \\
\hline SO & Q1 & 5 & 15 & 5 & 3 & 9 & 37 \\
\hline & Q2 & 6 & 12 & 4 & 4 & 10 & 36 \\
\hline & Q3 & 7 & 17 & 3 & 3 & 10 & 40 \\
\hline & Q4 & 4 & 9 & 7 & 1 & 5 & 26 \\
\hline ALL & Q1 & 14 & 56 & 22 & 8 & 30 & 130 \\
\hline & Q2 & 22 & 53 & 14 & 8 & 29 & 126 \\
\hline & Q3 & 25 & 48 & 12 & 7 & 21 & 113 \\
\hline & Q4 & 8 & 26 & 23 & 7 & 15 & 79 \\
\hline & TOTALS & $69(27 \%)$ & 183 & 71 & 30 & $95(21 \%)$ & 448 \\
\hline
\end{tabular}


From the total student sample, 21 percent $(n=95)$ of the students responded that they saw no change between the two years. Fifty-six percent $(n=252)$ of the students felt that their teachers knew then better during the block schedule year, while 27 percent $(n=69)$ of these students felt strongly that this was the case. Twenty-two percent ( $n=101)$ of the students felt that their teachers had been in less contact during the block schedule year. The quartile analysis revealed that the second and third quartile students felt a bit stronger that the teachers knew them better than the first and fourth quartile students did. Sixty percent $(n=75)$ of second quartile students and 65 percent $(n=73)$ of third quartile students felt that their teachers knew them better, while only 54 percent of first quartile students and 43 percent of fourth quartile students felt that this was the case.

In a similar manner, the first and fourth quartile students felt a bit stronger that the teachers did not know them as well during the block schedule year than the second and third quartile students did. Twenty-three percent $(n=30)$ of first quartile students and 38 percent $(n=30)$ of fourth quartile students felt that their teachers did not know them as well with the block schedule, while only 17 percent of second quartile students and 17 percent of third quartile students felt that this was the case.

Question 18: I know my teachers better this year.

$$
\begin{array}{ll}
\text { A -- strongly agree; } & B \text {-- agree; } \\
\text { C -- disagree } & C \text {-- strongly disagree; } \\
D \text {-- no difference between this year and last year }
\end{array}
$$

Table 26 shows the responses to this question from the students grouped according to their quartile and grade. 
Table 26

SUMMARY OF STUDENT RESPONSES BY QUARTILE AND AS A WHOLE TO QUESTION 18 OF THE ATTITUDE QUESTIONNAIRE

\begin{tabular}{|c|c|c|c|c|c|c|c|}
\hline & & $\begin{array}{c}\text { A } \\
\text { Strongly } \\
\text { Agree }\end{array}$ & $\begin{array}{c}\text { B } \\
\text { Agree }\end{array}$ & $\begin{array}{c}\mathrm{C} \\
\text { Disagree }\end{array}$ & $\begin{array}{c}\text { D } \\
\text { Strongly } \\
\text { Disagree }\end{array}$ & $\begin{array}{c}\text { E } \\
\text { No } \\
\text { Difference } \\
\text { Between } \\
\text { This Year } \\
\text { and Last } \\
\text { Year }\end{array}$ & TOTALS \\
\hline \multirow[t]{4}{*}{ SR } & Q1 & 7 & 21 & 9 & 1 & 9 & 47 \\
\hline & Q2 & 6 & 27 & 3 & 0 & 8 & 44 \\
\hline & Q3 & 5 & 17 & 4 & 0 & 5 & 31 \\
\hline & Q4 & 2 & 2 & 5 & 1 & 3 & 13 \\
\hline \multirow[t]{4}{*}{ JR } & Q1 & 6 & 20 & 8 & 0 & 12 & 46 \\
\hline & Q2 & 5 & 23 & 7 & 0 & 11 & 46 \\
\hline & Q3 & 6 & 24 & 5 & 1 & 6 & 42 \\
\hline & Q4 & 2 & 18 & 11 & 2 & 7 & 40 \\
\hline \multirow[t]{4}{*}{$\mathrm{SO}$} & Q1 & 5 & 17 & 5 & 1 & 9 & 37 \\
\hline & Q2 & 10 & 16 & 3 & 1 & 6 & 36 \\
\hline & Q3 & 6 & 20 & 4 & 0 & 10 & 40 \\
\hline & Q4 & 2 & 11 & 7 & 1 & 5 & 26 \\
\hline \multirow[t]{5}{*}{ ALL } & Q1 & 18 & 58 & 22 & 2 & 30 & 130 \\
\hline & Q2 & 21 & 66 & 13 & 1 & 25 & 126 \\
\hline & Q3 & 17 & 61 & 13 & 1 & 21 & 113 \\
\hline & Q4 & 6 & 31 & 23 & 4 & 15 & 79 \\
\hline & TOTALS & $62(22 \%)$ & 216 & 71 & 8 & $91(20 \%)$ & 448 \\
\hline
\end{tabular}

From the total student sample, 20 percent $(n=91)$ of the students responded that there was no difference between the two years. Sixty-two percent $(n=278)$ of the students felt that they knew their teachers better during the block schedule year, while 22 percent $(n=62)$ of the students who felt that they knew their teachers better their teachers strongly believed so. Only 18 percent $(n=79)$ of the students felt that they did not know their teachers better during the block schedule year.

The responses of the students in the second and third quartiles were a bit different than those of the other two quartiles. Sixty-six percent $(n=81)$ of the second 
quartile students and 68 percent $(n=74)$ of the third quartile students felt they knew their teachers better during the block year. Fifty-eight percent of the students in the first quartile and 50 percent of the students in the fourth quartile felt that this was the case.

Question 19: My teachers seem to be helping me more this year.
A -- strongly agree;
B -- agree;
C -- disagree;
D -- strongly disagree
$D$-- no difference between this year and last year

Table 27 shows the responses to this question from the students grouped according to their quartile and grade. From the total student sample, 27 percent $(n=120)$ of the students responded that they saw no change between the two years. Twenty percent ( $n=91$ ) of the students felt that their teachers seemed to be helping them more during the block schedule year, while 53 percent $(n=237)$ of the students felt that their teachers did not seem to be helping them more during the block schedule year. Eighteen percent $(n=42)$ of the students who felt that their teachers had not helped them as much strongly believed so.

The only noticeable difference in the grade and quartile analysis occurred with students grouped in the second quartile. Only 14 percent $(n=18)$ of these students responded that the teachers were not helping them as much during the block schedule year. The average of the other three quartiles for this type of response was 23 percent. 
Table 27

SUMMARY OF STUDENT RESPONSES BY QUARTILE AND AS A WHOLE TO QUESTION 19 OF THE ATTITUDE QUESTIONNAIRE

\begin{tabular}{|c|c|c|c|c|c|c|c|}
\hline & & $\begin{array}{c}\text { A } \\
\text { Strongly } \\
\text { Agree }\end{array}$ & $\begin{array}{c}\text { B } \\
\text { Agree }\end{array}$ & $\begin{array}{c}\mathrm{C} \\
\text { Disagree }\end{array}$ & $\begin{array}{c}\text { D } \\
\text { Strongly } \\
\text { Disagree }\end{array}$ & $\begin{array}{c}\text { E } \\
\text { No Difference } \\
\text { Between This Year } \\
\text { \& Last Year }\end{array}$ & TOTALS \\
\hline \multirow[t]{4}{*}{ SR } & Q1 & 4 & 20 & 7 & 3 & 13 & 47 \\
\hline & Q2 & 5 & 22 & 4 & 2 & 11 & 44 \\
\hline & Q3 & 2 & 14 & 7 & 1 & 7 & 31 \\
\hline & Q4 & 2 & 5 & 2 & 2 & 2 & 13 \\
\hline \multirow[t]{4}{*}{ JR } & Q1 & 5 & 20 & 7 & 2 & 12 & 46 \\
\hline & Q2 & 7 & 18 & 5 & 2 & 14 & 46 \\
\hline & Q3 & 4 & 21 & 6 & 1 & 10 & 42 \\
\hline & Q4 & 2 & 14 & 6 & 4 & 14 & 40 \\
\hline \multirow[t]{4}{*}{$\mathrm{SO}$} & Q1 & 2 & 17 & 5 & 3 & 10 & 37 \\
\hline & Q2 & 2 & 19 & 4 & 1 & 10 & 36 \\
\hline & Q3 & 5 & 17 & 5 & 3 & 10 & 40 \\
\hline & Q4 & 2 & 8 & 8 & 1 & 7 & 26 \\
\hline \multirow[t]{5}{*}{ ALL } & Q1 & 11 & 57 & 19 & 8 & 35 & 130 \\
\hline & Q2 & 14 & 59 & 13 & 5 & 35 & 126 \\
\hline & Q3 & 11 & 52 & 18 & 5 & 27 & 113 \\
\hline & Q4 & 6 & 27 & 16 & 7 & 23 & 79 \\
\hline & TOTALS & $42(18 \%)$ & 195 & 66 & 25 & $120(27 \%)$ & 448 \\
\hline
\end{tabular}

Question 20: Compare your feelings toward this year with your feelings

last year.

\section{A -- I like my teachers more this year. \\ B -- I like my teachers less this year. \\ C -- My feelings are about the same as last year.}

Table 28 shows the responses to this question from the students grouped according to their quartile and grade. 
Table 28

SUMMARY OF STUDENT RESPONSES BY QUARTILE AND AS A WHOLE TO QUESTION 20 OF THE ATTITUDE QUESTIONNAIRE

\begin{tabular}{|l|l|c|c|c|c|}
\hline & & $\begin{array}{c}\text { A } \\
\text { Liked More }\end{array}$ & $\begin{array}{c}\text { B } \\
\text { Liked Less }\end{array}$ & $\begin{array}{c}\text { C } \\
\text { Same as Last } \\
\text { Year }\end{array}$ & TOTALS \\
\hline SR & Q1 & 9 & 4 & 34 & 47 \\
\hline & Q2 & 14 & 2 & 28 & 44 \\
\hline & Q3 & 8 & 1 & 22 & 31 \\
\hline & Q4 & 2 & 2 & 9 & 13 \\
\hline & Q1 & 13 & 4 & 29 & 46 \\
\hline & Q2 & 14 & 3 & 29 & 46 \\
\hline & Q3 & 11 & 3 & 28 & 42 \\
\hline & Q4 & 5 & 12 & 23 & 40 \\
\hline & Q1 & 10 & 2 & 25 & 37 \\
\hline & Q2 & 11 & 2 & 23 & 36 \\
\hline & Q3 & 12 & 4 & 24 & 40 \\
\hline & Q4 & 7 & 7 & 12 & 26 \\
\hline & Q1 & 32 & 10 & 88 & 130 \\
\hline & Q2 & 39 & 7 & 80 & 126 \\
\hline & Q3 & 31 & 8 & 74 & 113 \\
\hline & Q4 & 14 & 21 & 44 & 79 \\
\hline & TOTALS & $116(26 \%)$ & $46(10 \%)$ & $286(64 \%)$ & 448 \\
\hline
\end{tabular}

From the total student sample, 64 percent $(n=286)$ of the students responded that their feelings didn't change between the two years. Twenty-six percent $(n=116)$ of the students felt that they liked their teachers more during the block schedule year, while 10 percent $(n=46)$ of the students felt that they liked their teachers less during the block schedule year.

There were differences in the grade and quartile analysis with this question. Students grouped in the fourth quartile were the only group of students who had a greater number of students respond that they liked their teachers less during the block schedule year. Twenty-seven percent of the fourth quartile students liked their teachers less during the block schedule year, while 17 percent responded that they liked their 
teachers more. The average of the responses of the other three quartiles were 6 percent for those who liked their teachers less and 28 percent for those who liked their teachers more during the block schedule year.

\section{Question 21: In general, what has been your attitude toward school for the} past two or three years?

\section{A -- I liked it; $\quad$ B -- I did not like it; \\ C -- My feelings were neutral}

Table 29 shows the responses to this question from the students grouped according to their quartile and grade. From the total student sample, 53 percent $(n=236)$ of the students responded that their feelings toward school have been neutral. Twenty-eight percent $(n=127)$ of the students responded that they had liked school over the past few years, while 19 percent $(n=85)$ responded that they had not liked school over the past few years. The responses of the students were very different within each of the quartiles for this question. The first quartile students had a much greater response of students who liked school over the past few years than those who did not $(+21)$. The second quartile and third quartiles were very similar in this area $(+12$ and +14 respectively), while the fourth quartile students contained fewer students who liked school than those who did not like school (-15).

Table 29

SUMMARY OF STUDENT RESPONSES BY QUARTILE AND AS A WHOLE TO QUESTION 21 OF THE ATTITUDE QUESTIONNAIRE

\begin{tabular}{|l|l|c|c|c|c|}
\hline & & $\begin{array}{c}\text { A } \\
\text { Liked It }\end{array}$ & $\begin{array}{c}\text { B } \\
\text { Did Not Like It }\end{array}$ & $\begin{array}{c}\text { C } \\
\text { Feelings Were } \\
\text { Neutral }\end{array}$ & TOTALS \\
\hline SR & Q1 & 15 & 7 & 25 & 47 \\
\hline
\end{tabular}




\begin{tabular}{|l|l|c|c|c|c|}
\hline & Q2 & 12 & 9 & 23 & 44 \\
\hline & Q3 & 8 & 5 & 18 & 31 \\
\hline & Q4 & 1 & 5 & 7 & 13 \\
\hline JR & Q1 & 16 & 7 & 23 & 46 \\
\hline & Q2 & 12 & 8 & 26 & 46 \\
\hline & Q3 & 16 & 6 & 20 & 42 \\
\hline & Q4 & 7 & 14 & 19 & 40 \\
\hline SO & Q1 & 16 & 2 & 19 & 37 \\
\hline & Q2 & 12 & 7 & 17 & 36 \\
\hline & Q3 & 10 & 9 & 21 & 40 \\
\hline & Q4 & 2 & 6 & 18 & 26 \\
\hline ALL & Q1 & 47 & 16 & 67 & 130 \\
\hline & Q2 & 36 & 24 & 66 & 126 \\
\hline & Q3 & 34 & 20 & 59 & 113 \\
\hline & Q4 & 10 & 25 & 44 & 79 \\
\hline & TOTALS & $127(28 \%)$ & $85(19 \%)$ & $236(53 \%)$ & 448 \\
\hline
\end{tabular}

Question 22: Consider whether your feelings toward school have changed under the new system with the four-period day.

A -- I like school more now.

B -- I like school less now.

C -- I feel about the same as in past years.

Table 30 shows the responses to this question from the students grouped according to their quartile and grade.

Table 30

SUMMARY OF STUDENT RESPONSES BY QUARTILE AND AS A WHOLE TO QUESTION 22 OF THE ATTITUDE QUESTIONNAIRE

\begin{tabular}{|l|l|c|c|c|c|}
\hline & & $\begin{array}{c}\text { A } \\
\text { Like School } \\
\text { More Now }\end{array}$ & $\begin{array}{c}\text { B } \\
\text { Like School } \\
\text { Less Now }\end{array}$ & $\begin{array}{c}\text { C } \\
\text { Feel Same as } \\
\text { in Past Years }\end{array}$ & TOTALS \\
\hline SR & Q1 & 10 & 11 & 26 & 47 \\
\hline & Q2 & 15 & 6 & 23 & 44 \\
\hline & Q3 & 7 & 4 & 20 & 31 \\
\hline & Q4 & 1 & 3 & 9 & 13 \\
\hline
\end{tabular}




\begin{tabular}{|l|l|c|c|c|c|}
\hline JR & Q1 & 12 & 11 & 23 & 46 \\
\hline & Q2 & 18 & 6 & 22 & 46 \\
\hline & Q3 & 16 & 6 & 20 & 42 \\
\hline & Q4 & 7 & 14 & 19 & 40 \\
\hline SO & Q1 & 12 & 7 & 18 & 37 \\
\hline & Q2 & 15 & 4 & 17 & 36 \\
\hline & Q3 & 15 & 5 & 20 & 40 \\
\hline & Q4 & 3 & 8 & 15 & 26 \\
\hline & QLL & 34 & 29 & 67 & 130 \\
\hline & Q2 & 48 & 16 & 62 & 126 \\
\hline & Q3 & 38 & 15 & 60 & 113 \\
\hline & Q4 & 11 & 25 & 43 & 79 \\
\hline & TOTALS & $131(29 \%)$ & $85(19 \%)$ & $232(52 \%)$ & 448 \\
\hline
\end{tabular}

From the total student sample, 52 percent $(n=232)$ of the students responded that they felt the same about school as they had in the past. Twenty-nine percent $(n=131)$ of the students felt that they liked school more during the block schedule year, while 19 percent $(n=85)$ of the students felt that they liked school less during the block schedule year.

The responses of the students in the second and third quartiles were much different than those of the other two quartiles. Thirty-eight percent $(n=48)$ of the second quartile students and 33 percent $(n=38)$ of the third quartile students felt they liked school better during the block year. Twenty-six percent of the students in the first quartile and 14 percent of the students in the fourth quartile felt that this was the case.

Question 23: I feel generally

\section{A -- more successful; $\quad B$-- less successful \\ $C$-- about the same degree of success as in the past}

Table 31 shows the responses to this question from the students grouped according to their quartile and grade. From the total student sample, 44 percent $(n=199)$ of the students responded that they saw no change between the two years. Forty-two percent 
$(n=186)$ of the students felt that they were having more success managing their schedule during the block schedule year, while 14 percent $(n=63)$ of the students felt that they were having less success managing their schedule during the block schedule year.

The responses by the first three quartiles were all very similar, with each group having over 40 percent of the students in their quartile responding that they felt they were having more success managing their schedule during the block schedule year. This was not the case with the fourth quartile students as only 32 percent $(n=25)$ of these students felt that this was the case. 
Table 31

SUMMARY OF STUDENT RESPONSES BY QUARTILE AND AS A WHOLE TO QUESTION 23 OF THE ATTITUDE QUESTIONNAIRE

\begin{tabular}{|l|l|c|c|c|c|}
\hline & & $\begin{array}{c}\text { A } \\
\text { More } \\
\text { Successful. }\end{array}$ & $\begin{array}{c}\text { B } \\
\text { Less } \\
\text { Successful }\end{array}$ & $\begin{array}{c}\text { C } \\
\text { Same Degree } \\
\text { of Success as } \\
\text { in the Past }\end{array}$ & TOTALS \\
\hline SR & Q1 & 23 & 5 & 19 & 47 \\
\hline & Q2 & 23 & 3 & 18 & 44 \\
\hline & Q3 & 14 & 4 & 13 & 31 \\
\hline & Q4 & 4 & 4 & 5 & 13 \\
\hline JR & Q1 & 18 & 6 & 22 & 46 \\
\hline & Q2 & 21 & 4 & 21 & 46 \\
\hline & Q3 & 16 & 6 & 20 & 42 \\
\hline SO & Q4 & 13 & 10 & 17 & 40 \\
\hline & Q1 & 15 & 5 & 17 & 37 \\
\hline & Q2 & 14 & 3 & 19 & 36 \\
\hline & Q3 & 17 & 6 & 17 & 40 \\
\hline ALL & Q4 & 8 & 7 & 11 & 26 \\
\hline & Q1 & 56 & 16 & 58 & 130 \\
\hline & Q2 & 58 & 10 & 58 & 126 \\
\hline & Q3 & 47 & 16 & 50 & 113 \\
\hline & Q4 & 25 & 21 & 33 & 79 \\
\hline & TOTALS & $186(42 \%)$ & $63(14 \%)$ & $199(44 \%)$ & 448 \\
\hline
\end{tabular}

Question 24: I am experiencing stress related to school this year.
A -- more;
B -- less;
C-- About the same

Table 32 shows the responses to this question from the students grouped according to their quartile and grade. From the total student sample, 36 percent $(n=162)$ of the students responded that they saw no change between the two years. Thirty percent ( $n=136$ ) of the students felt that they were experiencing more stress during the block schedule year, while 34 percent $(n=150)$ of the students felt that they were experiencing less stress during the block schedule year. There was very little difference between the responses of the students within the quartiles or grades to this question. 
Table 32

SUMMARY OF STUDENT RESPONSES BY QUARTILE AND AS A WHOLE TO QUESTION 24 OF THE ATTITUDE QUESTIONNAIRE

\begin{tabular}{|c|c|c|c|c|c|}
\hline & & $\begin{array}{c}\text { A } \\
\text { More } \\
\text { Stress } \\
\end{array}$ & $\begin{array}{c}\text { B } \\
\text { Less } \\
\text { Stress } \\
\end{array}$ & $\begin{array}{c}\text { C } \\
\text { About the } \\
\text { Same }\end{array}$ & TOTALS \\
\hline \multirow[t]{4}{*}{ SR } & Q1 & 13 & 19 & 15 & 47 \\
\hline & Q2 & 14 & 15 & 15 & 44 \\
\hline & Q3 & 8 & 10 & 13 & 31 \\
\hline & Q4 & 3 & 5 & 5 & 13 \\
\hline \multirow[t]{4}{*}{ JR } & Q1 & 14 & 14 & 18 & 46 \\
\hline & Q2 & 15 & 17 & 14 & 46 \\
\hline & Q3 & 15 & 13 & 19 & 47 \\
\hline & Q4 & 14 & 15 & 13 & 42 \\
\hline \multirow[t]{4}{*}{$\mathrm{SO}$} & Q1 & 11 & 12 & 14 & 37 \\
\hline & $\mathrm{Q} 2$ & 12 & 11 & 13 & 36 \\
\hline & Q3 & 10 & 15 & 15 & 40 \\
\hline & Q4 & 7 & 4 & 8 & 19 \\
\hline \multirow[t]{5}{*}{ ALL } & Q1 & 38 & 45 & 47 & 130 \\
\hline & Q2 & 41 & 43 & 42 & 126 \\
\hline & Q3 & 33 & 38 & 47 & 118 \\
\hline & Q4 & 24 & 24 & 26 & 74 \\
\hline & TOTALS & $136(30 \%)$ & $150(34 \%)$ & $162(36 \%)$ & 448 \\
\hline
\end{tabular}

Question 25: Considering all your impressions about the four-period block schedule, select a response.
A -- I would like to remain on the four-period day.
B -- I would like to return to a seven-period day.
C -- Both programs are about the same, so it doesn't matter

Table 33 shows the responses to this question from the students grouped according to their quartile and grade. 
Table 33

SUMMARY OF STUDENT RESPONSES BY QUARTILE AND AS A WHOLE TO QUESTION 25 OF THE

ATTITUDE QUESTIONNAIRE

\begin{tabular}{|l|l|c|c|c|c|}
\hline & & $\begin{array}{c}\text { A } \\
\text { Remain on } \\
\text { Four-Period } \\
\text { Day }\end{array}$ & $\begin{array}{c}\text { B } \\
\text { Return to } \\
\text { Seven-Period } \\
\text { Day }\end{array}$ & $\begin{array}{c}\text { C } \\
\text { Both Same -- } \\
\text { Doesn't Matter }\end{array}$ & TOTALS \\
\hline SR & Q1 & 14 & 7 & 26 & 47 \\
\hline & Q2 & 29 & 7 & 8 & 44 \\
\hline & Q3 & 15 & 8 & 8 & 31 \\
\hline & Q4 & 3 & 6 & 4 & 13 \\
\hline JR & Q1 & 19 & 12 & 15 & 46 \\
\hline & Q2 & 32 & 5 & 9 & 46 \\
\hline & Q3 & 23 & 8 & 11 & 42 \\
\hline & Q4 & 14 & 16 & 10 & 40 \\
\hline SO & Q1 & 15 & 10 & 12 & 37 \\
\hline & Q2 & 23 & 5 & 8 & 36 \\
\hline & Q3 & 22 & 9 & 9 & 40 \\
\hline & Q4 & 11 & 9 & 6 & 26 \\
\hline ALL & Q1 & 48 & 29 & 53 & 130 \\
\hline & Q2 & 84 & 17 & 25 & 126 \\
\hline & Q3 & 60 & 25 & 28 & 113 \\
\hline & Q4 & 28 & 31 & 20 & 79 \\
\hline & TOTALS & $220(49 \%)$ & $102(23 \%)$ & $126(28 \%)$ & 448 \\
\hline
\end{tabular}

From the total student sample, 28 percent $(n=126)$ of the students responded that it did not make a difference on the type of schedule they had. Forty-nine percent $(n=220)$ of the students preferred to stay on the four period day, while 23 percent $(n=102)$ of the students would rather return to the seven period day. There were a few notable differences within the quartiles with this question. The first quartile comprised 42 percent $(n=53)$ of the responses of no preference to type of schedule. The second quartile had the highest percentage of students who favored the block schedule with 67 percent $(n=84)$, while 53 percent $(n=60)$ of third quartile students shared this preference. The first quartile had 37 percent $(n=48)$ of its members respond in preference of the block system while 35 percent $(n=28)$ of the fourth quartile students 
also preferred the four period day. In addition, the fourth quartile was the only quartile where there were more responses in favor of the seven period day than responses in favor of the four period day.

\section{Question 26: Additional comments about anything related to the four-four plan.}

Only 9 percent $(n=41)$ of the students gave feedback on this question (Appendix F). From the complete sample that responded to this question, the largest number of responses were that they "enjoyed their block classes except where teachers lectured too long" or that "some teachers lecture too much." There did not seem to be a pattern of responses within any of the quartiles when attempting to view these responses according to their quartiles.

Summary

The summary chart illustrates the improvement from the 1997-1998 school year to the 1998-1999 school year. The aggregated grade point and absence improvement indicates the percentage of growth for students in each quartile. 
AGGREGATED GRADE POINT AND ATTENDANCE IMPROVEMENT FROM 1997-1998 SCHOOL YEAR TO 1998-1999 SCHOOL YEAR

\begin{tabular}{|c|c|c|c|c|c|}
\hline CHART 1 & & $\overline{\text { Q1 }}$ & Q2 & Q3 & Q4 \\
\hline $\begin{array}{l}\text { GRADE } \\
\text { POINT } \\
\text { IMPROVEMENT }\end{array}$ & $\begin{array}{c}\text { SOPH } \\
\text { JUNIOR } \\
\text { SENIOR }\end{array}$ & $54 \%(n=81)$ & $72 \%(n=110)$ & $66 \%(n=95)$ & $42 \%(n=55)$ \\
\hline
\end{tabular}

\begin{tabular}{|l|c|c|c|c|c|}
\hline \multicolumn{1}{|c|}{ CHART1 } & & Q1 & Q2 & Q3 & Q4 \\
\hline ABSENCE & $\begin{array}{c}\text { SOPH } \\
\text { JUNIOR } \\
\text { IMPROVIOR }\end{array}$ & $49 \%(n=73)$ & $73 \%(n=112)$ & $73 \%(n=106)$ & $57 \%(n=75)$ \\
\hline
\end{tabular}

Sophomore, junior, and senior students in the first quartile gained 54 percent improvement in grade point average and 49 percent increase in attendance.

In the second quartile, students show a 72 percent $(n=110)$ increase in grade point average and a 73 percent $(n=112)$ improvement in attendance. Students in quartile three, show a gain of 66 percent $(n=95)$ in grade point average, while the attendance improvement is 73 percent $(n=106)$.

Fourth quartile students have a 42 percent $(n=55)$ gain in grade point average. The attendance improvement for quartile four is 57 percent $(n=75)$ for the aggregated sophomores, juniors, and seniors.

It can be seen that students within the aggregated second and third quartile show a higher percentage of improvement for both grade point average and attendance. Students in the first and fourth quartile also show improvement.

Student attitude information was gathered from a 26 question survey. Twentythree of the 26 questions were analyzed to determine student attitude. The first two questions on the survey determined the eligibility of students to participate in the study; 
where they attended school the previous year and their grade level. Questions 21 and 22 are worded to assess the attitude of students toward the change to the modified $4 \mathrm{x}$ 4 block schedule.

The overall student attitude to the change to block scheduling was positive. Responses to 19 of the 23 questions on the survey were favorable. The results, as illustrated in the chapter tables, reveal that while students in each of the four quartiles record positive responses, the attitude toward the change was more positive with students in the second and third quartile. 


\section{CHAPTER FIVE}

Summary, Conclusions, and Recommendations

\section{Purpose of the Study}

The purpose of this study was to examine the differences in groupings of students' academic achievement, attitude, and attendance as a school made the change from a traditional schedule to a modified $4 \times 4$ block schedule. The total student population for the school used for this study during the 1997-1998 school year was 860 and for the $1998-1999$ school year was 876 . The factors to be studied were analyzed descriptively as a whole and within the specific groupings established for this study. All students involved had attended the school chosen for this study during the 1997-1998 school year under a traditional schedule, and the 1998-1999 school year under a modified $4 \times 4$ block schedule.

The sophomore class, during the 1998-1999 school year, yielded a sample of 187 eligible participants for this study. The junior class sample consisted of 197 participants, and the senior class sample contained 196 participants. The student population was distributed into quartiles within each grade. The first quartile represents the top 25 percent academically achieving students based on grade point averages for the 1997-1998 school year; the second quartile represents the second 25 percent academically achieving students based on grade point averages for the 1997-1998 school year. The third quartile represents the third 25 percent academically achieving students based on grade point averages for the 1997-1998 school year, while the fourth quartile represents the lowest 25 percent academically achieving students for the 19971998 school year.

\section{Summary of Procedures}

In January of 1999, all data with regard to academic achievement and attendance for the 1997-1998 school year were gathered from the targeted school. 
From this information, the quartiles to be used for the study were established, based on the grade point averages of the students for the 1997-1998 school year.

In May of 1999, the parents of the students, who were minors during the time of the study, were asked to sign a consent form and all participants were asked to fill out an assent form. These forms were collected from the students. All students eligible to participate in the study were asked to complete the attitude questionnaire. The completed questionnaires were collected and the data were recorded according to the quartiles and grades of the respective students.

In June of 1999, data with regard to academic achievement and attendance for the 1998-1999 school year were gathered from the targeted school. Students meeting all criteria to be participants in the study were identified by their appropriate quartiles at that time based on the data collected during the 1997-1998 school year. Each student's grade point average and attendance from the 1997-1998 school year then was compared to the student's grade point average and attendance from the 19981999 school year.

$\underline{\text { Student Achievement }}$

Student achievement was based on a comparison of grade point averages for each student from the 1997-1998 school year to the 1998-1999 school year. These data were descriptively analyzed from the total student sample, within the quartiles established for the overall school sample, and through the quartiles established within each grade.

The student body, as a whole, had a mean growth in grade point average over the two years period of 0.05 . Students on average in the first three quartiles improved their grade point average. Although 10 of the 12 quartile groups had positive growth in grade point average, students in the second and third quartiles had much greater gains than the students in the first or fourth quartiles. The second quartile students showed a mean growth in grade point average of .091 points, while the students in the third 
quartile showed a mean growth of .099 points. These improvements are nearly triple the average amount of improvement made by first quartile students who had a mean growth of .037 points. The fourth quartile students overall showed a mean decrease of .032 points in grade point average. The highest six of the 12 quartiles showing improvement all came from the second or third quartiles of each grade.

In addition to mean scores, the number and percentage of students who improved their grade point average during the block schedule year was examined by group. Over 50 percent of the first three quartile students in the sample population had an increased grade point average during the 1998-1999 school year. The students in the fourth quartile had less than 50 percent of its sampled students showing growth in grade point average.

Although nine of the 12 quartile groups had over 50 percent of their students showing improvement in grade point average, students in the second and third quartiles had much greater gains than the students in the first or fourth quartiles. Seventy-two percent of the second quartile students showed improvement in grade point average while 66 percent of the students in the third quartile showed improvement in this area. Only 54 percent of the first quartile students and 42 percent of the fourth quartile students overall showed an increase in grade point average. In addition, all six of the quartiles by grade in the second or third quartiles had at least 60 percent of its students showing improvement in grade point average. Only one of the six quartiles by grade in the first and fourth quartiles had at least 60 percent improvement in grade point average. 
Student Attendance

Student attendance was based on a comparison of student absences for each student from the 1997-1998 school year to the 1998-1999 school year. These data were analyzed descriptively from the total student sample, within the quartiles established for the overall school sample, and through the quartiles established within each grade.

The student body, as a whole, had a mean reduction in absenteeism over the two-year period of 4.62 days. Students in all four quartiles improved their attendance on average. Students in all four quartiles showed improvement in their attendance, but there was a large range in the amount of improvement when comparing the quartiles to each other. The students in the third quartile had an average improvement in attendance of 7.83 days, while the students in the second quartile had an average improvement in attendance of 5.64 days. The fourth quartile students improved their attendance by 3.46 days on average, while the first quartile students averaged 1.36 days of improvement in attendance.

The highest six of the 12 quartiles showing improvement all came from the second or third quartiles of each grade. The average improvement in attendance in each of these quartiles was at least 5.5 days, with the senior third quartile having the most improved attendance with a mean improvement of 9.87 days. In contrast, neither the first nor the fourth quartile students at any grade had an average improvement of 4.5 or higher, and the senior first quartile students only had a mean improvement of .26 days.

In addition to mean scores within the quartiles, each quartile was examined to determine the number and percentage of students who improved their attendance during the block schedule year. The students in the last three quartiles all showed over half of their sampled members with an increase in attendance. The sampled students in the first quartile had less than 50 percent growth in attendance. 
Although nine of the 12 quartile groups had over 50 percent of their students showing improvement in attendance, students in the second and third quartiles had a much greater level of improvement than the students in the first or fourth quartiles. Seventy-three percent of the second and 73 percent of the third quartile students showed improvement in attendance, while 49 percent of the first quartile students, and 57 percent of the fourth quartile students overall showed an increase in attendance. Additionally, all six of the quartiles by grade in the second or third quartiles had at least 67 percent of its students showing improvement in attendance. None of the six quartiles by grade in the first and fourth quartiles achieved this percentage of improvement.

\section{Student Attitude}

All student attitude information was gathered from a student survey. This survey consisted of 26 questions, the first 25 of which were multiple choice. Each set of responses to a question was analyzed individually. These data were analyzed descriptively from the total student sample responses, within the quartiles established for the overall school sample, and through the quartiles established within each grade (Appendix G).

The first two questions were used to determine and verify the students' qualifications to participate in the study. These questions did not have any bearing on student attitude toward the change to block scheduling. Questions 21 and 22 were used to assess pre- and post block scheduling attitude toward school, so together the two questions assess one change. The remaining 22 questions were used to measure the students' attitude toward the change to the block schedule, resulting in 23 indicators regarding student attitude.

As a whole, the students' attitudes were strong toward the change to block scheduling. Of the 23 indicators measured, 19 showed a more favorable response toward the change to block scheduling. The only negative indicators regarding this 
change were that the teachers lectured too much, there seemed to be more disruptive behavior in the classroom, students seemed less attentive in class, and that teachers had less contact with the parents during the block scheduling year.

The first three negative results listed all seem to tie together and are consistent with the research. If teachers lecture too much, then the students will be less attentive, which then would lead to disruptive behavior in the classroom. The fourth indicator listed as negative could also be seen as a positive result. Parent-Teacher relationships are important in educating children, but if the students are attending class more regularly and performing better in class under the block schedule system as determined by this study, then this could be the reason students feel that there was less teacher contact with the parent during the block schedule year.

There was a great deal of difference in the responses to the questions by quartile. Although the overall attitude toward the change to block scheduling was very positive, the fourth quartile had the most negative attitude toward the change. The fourth quartile students responded differently than the other three quartile groups toward six questions.

Question 3: With the new block schedule this year, I believe I am understanding my lessons better than last year.

Question 12: How many of your teachers lecture too much?

Question 15: I find that the general behavior of students (corridors, commons, class change, etc.) is

Question 20: Compare your feelings toward this year with your feelings last year.

Question 21: In general, what has been your attitude toward school for the past two or three years? and all six were negative differences toward the change to block scheduling. They were the only group of students who differed from the others in a negative manner. 
The first group also had some differences in their responses to the questions as compared to the other three groups. There was one question where they had a more positive outlook on the change to block scheduling than the other three groups.

Question 21: In general, what has been your attitude toward school for the past two or three years?

More significantly, there were six questions where the first quartile students gave a large number of responses that there was no change between the two years in the indicator measured.

Question 4: My grades for this nine weeks this year were generally than in the past.

Question 6: I am experiencing confusion about homework assignments this year.

Question 7: I am finding it to complete my homework assignments this year.

Question 11: I seem to be learning this year.

Question 17: My teachers seem to know me better this year.

Question 25: Considering all your impressions about the four-period block schedule, select a response.

The attitude of the second quartile and third quartile students was the most positive toward the change to block scheduling. There were nine questions where the second and third quartile students showed much stronger positive outlooks on the change to block scheduling than the students in the other two quartiles.

Question 4: My grades for this nine weeks this year were generally than in the past.

Question 7: I am finding it to complete my homework assignments this year.

Question 9: I like learning better in ninety-minute blocks of time. 
Question 11: I seem to be learning this year.

Question 15: I find that the general behavior of students around the school (corridors, commons, class changes, etc.) is

Question 17: My teachers seem to know me better this year.

Question 18: I know my teachers better this year.

Question 22: Consider whether your feelings toward school have changed under the new system with the four-period day.

Question 25: Considering all your impressions about the four-period block schedule, select a response.

The second quartile students also had two additional questions where they stood out from all of the other quartiles in a positive manner.

Question 11: I seem to be learning this year.

Question 25: Considering all your impressions about the four-period block schedule, select a response.

$\underline{\text { Considerations }}$

The results of this study strongly indicate that the change to the modified $4 \times 4$ block schedule are positive according to the variables measured in this study. Also, it has shown that the students' achievement, attendance, attitude most positively affected by this change are the second and third quartile students. There are, however, several considerations that should be addressed when reviewing these results.

As the results of the study indicate, moving to the modified $4 \times 4$ block schedule is positive. It should be noted that due to the desire of teachers and students to seek comfort in past practices (traditional schedule), a select group of staff and students appeared passive and somewhat skeptical regarding the change to the modified $4 \times 4$ block schedule. The change to block scheduling will be different at each school. Fullan 
(1993) indicates that "Changing formal structures is not the same as changing norms, habits, skills and beliefs" (p. 49).

In measuring grade point average improvement, the amount of improvement possible is inversely proportional to the ranking of the students by quartile. Although these data accurately show the amount of improvement as well as the number and percentage of students within each quartile showing improvement, students in the higher quartiles have a much smaller area in which to improve in grade point average than students in lower quartiles.

Although attendance is not directly affected by grade point average, students generally will attain higher grade point averages when they have better attendance. This was the case in this study as each quartile from highest to lowest had a high mean absence rate. In a similar manner, as mentioned above, with grade point averages the amount of improvement possible in attendance was inversely proportional to the ranking of the students by quartile is more difficult to improve. Again, although the data accurately show the amount of improvement as well as the number of percentage of students within each quartile showing improvement, students in the higher quartiles have a much smaller area in which to improve their attendance than students in lower quartiles.

Although all of these variables will have an impact on results, the only variable that was changed for all participants in this study over the two-year period was the change in the schedule structure from a traditional to a modified $4 \times 4$ block schedule. Additionally, the change to a modified $4 \times 4$ block schedule may have provided results that would not have been seen in a different form of block scheduling. 


\section{$\underline{\text { Conclusions }}$}

Organizational change is an important process in restructuring for positive results for students. The more teachers understand the demands of change and the impact it has on students' achievement, attitude, and attendance, the more likely they are to support the efforts of the change. Fullan (1991) indicated that change is often adopted without understanding it.

The challenge of the principal is to focus on the leadership role as one of collaboration (Fullan and Hargreaves, 1996). Empowering teachers provides the professionalism needed to gain the confidence to meet the challenge. The needs of the staff, as addressed by Tewel (1991) also indicate the necessity and importance of professional staff development.

Teachers and teacher teams were involved in the complete process of change from the traditional schedule to the modified $4 \times 4$ block schedule. Visitations to other schools that had previously implemented the schedule change, as well as presents by resource individuals, assisted in establishing a knowledge base. Question-Answer sessions were provided, as well as teamwork research to review past practices. In the initial stages, this professional development afforded the staff with the opportunity to assist effectively in the decision making process.

Some teachers enrolled in graduate classes that focused on various models of teaching, while others reviewed the literature for innovative methods, and still others conferenced among themselves. Although, not initially, the change to the modified $4 \mathrm{x}$ 4 block schedule later appeared to renew the enthusiasm and the motivation teachers had for teaching.

The move from the traditional schedule to the modified $4 \times 4$ block schedule has allowed teachers the opportunity to varying their instructional strategies. In turn, this move has been a positive factor for students by increasing their mean grade point average, attendance, and by having a more positive attitude toward learning. The study 
results gives additional credibility to the comment by Canady and Rettig (1995) in which they indicate that one of the most important factors in the success of block scheduling is the degree in which teachers vary their instructional strategies.

The increase in achievement, attendance, and attitude as determined by the results of the analyzed data further supports the research in these areas (Marshak, 1997; Anderson, 1994; Edwards, 1995; Canady and Rettig, 1993, 1995, 1998; and Hampton, 1997). More in-depth learning opportunities, more individual attention, varied instructional strategies, as well as fewer classes, and a more relaxed environment added to the overall, positive results in the three areas emphasized: achievement, attendance, and attitude.

A significant result of the study is the impact the change from the traditional schedule to the modified $4 \times 4$ block schedule had on those students grouped in Quartile 2 (26-50\%) and student groups in Quartile 3 (51-75\%).

Littky and Allen (1999) address the need for instructional decisions to meet the needs of "kids in the middle" (p. 25). Students in these two quartiles showed the most significant, positive results in achievement, attendance, and attitude. Although restructuring decisions are made for the best interest of all students, sometimes the needs of the "students in the middle" are often not the real concern. 
Implications for the Profession

The school used in this study spent extensive time preparing for the change from a traditional schedule to a modified $4 \times 4$ block schedule. Two years prior to implementing the modified $4 \times 4$ block schedule, a small group of staff explored the various styles of block scheduling. The year prior to implementation, this school used 18 two-hour staff development dates to prepare the teaching staff for the change.

These staff development opportunities included an awareness stage, an instruction and methods development stage, and a preparation stage. The organizational change theory applied in this setting was critical to the success of the implementation of the modified $4 \times 4$ block schedule.

It is recommended that an administrator devote adequate time to acclimate and educate staff, students, parents, and community members to the benefits of block scheduling before implementing. It is also recommended that administrators take the time to provide staff development to the teaching staff to insure that staff has the ability to vary their instruction. The variation of instruction provides a climate where student attitude and attendance are enhanced and also meet the variety of learning needs, interests, and abilities of students which increase the opportunity for more positive academic success.

\section{$\underline{\text { Recommendations }}$}

There are several recommendations that would add reliability to the results of this study. The results of this study strongly indicate that the change to a modified $4 \times 4$ block scheduling is positive according to the variables measured in this study, and that the students most positively affected by this change are the second and third quartile students. The limitations of this study need to be recognized, but additional research could minimize the effect of the limitations.

A new study involving the students who participated in this study during their second year of block scheduling at this same school would be one way to minimize the 
effect of some of the limitations listed. Another way to minimize the effects of some of these limitations would be to repeat this study at another school going through a change from a traditional to a modified $4 \times 4$ block schedule.

One concern regarding this study could be whether or not the style of block scheduling implemented had an effect on the change. It is recommended that this study be repeated at another school where a different style of block scheduling is being implemented. Additionally, the age of the students involved in this study could be another factor in question. It is recommended that this study be repeated at a middle school or a school consisting of grade levels from those which were investigated in this study. 


\section{WORKS CITED}

Anderson, B. L. (1993). The stages of systemic change. Educational Leadership, 14-17.

Anderson, J. (1994). Intensive scheduling: An interesting possibility. The Clearing House, 56, 26-28.

Bevevino, Mary M. Snodgrass, Dawn M., Adams, Kenneth M., and Dengel, Joan A. (1999). An Educator's Guide to Block Scheduling, Needham Heights, MA., Allyn and Bacon, 13.

Bolman, L. G. \& Terrence, E. D. (1997). Reframing Organizations. San Francisco, CA: Jossey-Bass Publishers.

Bonsting, J. J. (1992). The quality revolution in education. Educational Leadership, 50, 4-9.

Boyer, Ernest L. (1983). High School: A Report on Secondary Education in America. San Francisco, CA: Harper and Row.

Boyer, E. (1983). The American High School. American Educator, 30-33.

Brandenburg, A. C. (1995). An analysis of block scheduling models and their impact on a positive school climate. Unpublished doctoral dissertation. Malibu, CA:

Pepperdine University.

Bush, Gail. (September 1998). Prophets in your own backyard. Educational Leadership, 56(1), 46-50.

Canady, R. L. and Rettig, M. D. (1998). Block Scheduling: What We've Learned. Manuscript submitted for publication. 
Canady, R. L. \& Rettig, M. D. (1995). Block Scheduling: A Catalyst for Change in High Schools. Eye on Education.

Canady, Robert Lynn and Rettig, Michael D. (1995). "The Power Of Innovative Scheduling." Educational Leadership, Vol. 53, No. 3.

Canady, R. L. \& Rettig, M. D. (1993). Unlocking the lockstep high school schedule. Phi Delta Kappan, 75, 310-314.

Carroll, Joseph. (1994). The Copernican Plan Evaluated: The Evolution of a Revolution. Topsfield, MA: The Copernican Association, Ltd..

Carroll, Joseph. (1994). Phi Delta Kappan, 76(2), 105-113.

Carroll, Joseph. (1994). "Organizing Time To Support Learning." The School Administrator, 51(3), 26-38, 30-33.

Carroll, Joseph M. (1990). "The Copernican Plan: Restructuring the American High School.” Phi Delta Kappan, 75, 5.

Carroll, Joseph M. (1989). The Copernican plan. Andover, MA: The Regional Laboratory for Educational Improvement of the Northeast and Islands.

Cawelti, G. (1997). Effects of high school restructuring: Ten schools at work. Arlington, VA: Educational Research Service.

Cawelti, G. (1994). "High School Restructuring: A National Study." Arlington, VA: Educational Research Service.

Cohen, Elizabeth. (September 1998). Making cooperative learning equitable. Educational Leadership, 56(1), 18-21.

Covey, S. R. (1990). The seven habits of highly effective people. New York: Fireside. 
Covey, S. (1989). The 7 Habits of Highly Effective People. New York: Simon \& Shuster.

DiRocco, Mark D. (December 1998-January 1999). How An Alternating-Day

Schedule Empowers Teachers. Educational Leadership, 56(4), 82-84.

Duke, Daniel L. (May, 1998). "Challenges of Designing the Next Generation of America's Schools." Phi Delta Kappan, Vol. 79, No. 9, 693.

Edwards, C. M. (1995). The 4 x 4 plan. Educational Leadership, 53, 16-19.

Edwards, Clarence M., Jr. (May, 1995). Virginia’s 4/4 High Schools: High

School, College, and More. NASSP Bulletin, 79, 571, pp. 23-41.

Edwards, C. M. (May, 1993). Restructuring to improve student performance. NASSP Bulletin, 77, 77-88).

Eineder, D. V. and Bishop, H. L. (May, 1997). Block scheduling the high school:

The effects on achievement, behavior, and student-teacher relationships. NASSP Bulletin, 45-54.

Eineder, D. V. (1996). The effects of block scheduling in a high school. (Doctoral dissertation, University of Alabama, 1996). Dissertation Abstracts International, 58, AAC9726327.

Evans, Robert. (1996). The human side of school change. San Francisco, CA: Jossey-Bass, Inc.

Fiske, E. G. (1991). Smart schools, smart kids. New York: Touchstone.

Fitzpatrick, J. E. and Mowers, M. (1997). Success and the four block schedule: Stakeholder's bring in! NASSP Bulletin, 81, 51-56.

Fleming, D., Olenn, V., Schoenstein, R. and Eineder, D. (1997). Moving to the 
block: Getting ready to teach for extended periods of time. Washington, DC: National Education Association.

Franks, George N. (1999). Block scheduling and its impact on the academic achievement and behavior of students in a high school with regard to gender: An exploratory study. (Unpublished doctoral dissertation). Wilmington College.

Fullan, Michael and Andy Hargreaves. (1996). What's worth fighting for in your school. New York: Teachers College Press.

Fullan, Michael. (1993). Change forces: Probing the depths of educational reform. London: The Falmer Press.

Fullan, M. and Miles, M. (1992). "Getting Reform Right: What Works and What Doesn't." Phi Delta Kappan, 10.

Fullan, M. with Stiegelbauer, S. (1991). The new meaning of educational change. New York: Teachers College Press.

Geismar, T. J. \& Pullease, B. G. (1996). The trimester: A competency based model of block scheduling. National Association of Secondary School Principals, 80, 95105.

Glasser, W. (1992). The Quality School: Managing Students Without Coercion. New York, NY: Harper Collins.

Glasser, W. (1991). The quality school. New York: Harper Collins.

Glatthorn, Allen A. (1997). The principal as curriculum leader. California: Corwin Press.

Goldman, J. J. (1983). Flexible modular scheduling: Results of evaluation in its second decade. Urban Education, 18, 191-228. 
Gorman, B. W. (1971). Secondary education: The high school America needs.

New York: Random House.

Hackmann, D. G. (1995). Improving school climate: Alternating-day block schedule.

Schools in the Middle, 5, 28-34.

Hackmann, D. G. (1995). Ten Guidelines For Implementing Block Scheduling.

Educational Leadership, 53(3), 24-27.

Hampton, D. (1997). Strengthening your block schedule program: Practical

teaching strategies for extended class periods. Medina, WA: Institute for

Educational Development.

Holtzman, M. (1993). What is systemic change? Educational Leadership, 18.

Hottenstein, D. S. (1999). Block scheduling's success formula. The School

Administrator, 56(3), 23-26.

Hottenstein, D. and Malatesta, C. (1993). Putting a school in gear with intensive scheduling. The High School Magazine, 1, 28-29.

Hurley, Casey J. (December, 1997). "The 4 x 4 Block Scheduling Model: What

Do Students Have To Say About It? NASSP Bulletin, 81, 593.

King, B. B. (1996). The effects of block scheduling on learning environment, instructional strategies, and academic achievement. (Doctoral dissertation, University of Central Florida). Dissertation Abstracts International, 57, ACC9636923.

Kruse, C. A. and Kruse, G. D. (1995). The master schedule and learning: Improving the quality of education. NASSP Bulletin 79, 1-8. 
Littky, Dennis, Allen, Farrell. (September 1999). Whole school personalization, one student at a time. Educational Leadership, 57(1), 24-28.

Loveless, Tom. (April 1999). Will tracking reform promote social equity? Educational Leadership, 56(7), 28-32.

Lunenburg, Fred C. and Orstein, Allan C. (2000). Educational administration, concepts and practices, Third Edition. California: Wadsworth/Thomas.

Marsh, Myranda. (1999). "Life Inside A School: Implications for Reform in the 21st Century." ASCD Yearbook.

Marshak, D. (1997). Action research on block scheduling. Princeton, NJ: Eye on Education.

Miller, E. (1992). Breaking The Tyranny of the Schedule. The Harvard Education Letter, 24, 4-7.

Mistretta, G. M. \& Polansky, H. B. (1997). Prisoners of time: Implementing a block schedule in the high school.

Monroe, M. J. (1989). Block: Successful alternative format addressing learner learner needs. Paper presented at the Annual Conference of the Association of Teacher Educators, St. Louis, MO.

National Education Commission on Time and Learning. (September, 1994). "Prisoners of Time: Research." "What We Know and What We Need To Know. Report of the National Education Commission on Time and Learning." Washington, DC: U.S. Government Printing Office.

Nelson, Wade W. (January 1999). The emperor redux: Extending the Minnesota metaphor. Phi Delta Kappan, 50(5), 387-393. 
Northwest Regional Educational Laboratory, Rural Education Program. (January, 1990). "Literature Search on the Question: What Are the Advantages and Disadvantages of Various Scheduling Options for Small Secondary Schools (High Schools and Middle Schools)?" Portland, OR: Author.

Oladele, Folasade. (December 1998-January 1999). Passing down the spirit. Educational Leadership, 56(4), 62-65.

O’Neil, J. (1995). Finding Time To Learn. Educational Leadership, 53(3), 11-15.

Queen, J. A. \& Gaskey, K. A. (1997). Steps for improving school climate in block scheduling. Phi Delta Kappan, 158-161.

Reid, W. M., Hierck, T. \& Vergin, L. (1995). Measurable pains of block scheduling. The School Administrator, 51(3), 32-33.

Renzulli, J. S., ed. (1986). Systems and models for developing programs for the gifted and talented. Mansfield Center, CONN: Creative Learning Press.

Rettig, M. D. \& Canady, R. L. (1999). The effects of block scheduling. The School Administrator, 56(3), 14-22.

Rettig, M. D. \& Canady, R. L. (1996). All around the block: The benefits and challenges of a non-traditional school schedule. The School Administrator, $\underline{8,(53),}$ 8-15.

Santos, K. S. \& Rettig, M. D. (1998). Meeting the Needs of Special Education Students in a High School Block Schedule. Manuscript submitted for publication. Harrisonburg, VA: James Madison University.

Sarason, S. Revisiting the culture of the school and the problem of change. New York: Teachers College Press. 
Sarason, Seymour Bernard. (1993). The case for change. San Francisco, CA: Jossey-Bass.

Scherer, Marge. (September 1998). A conversation with Herb Kohl. Educational Leadership, 56(1), 8-13.

Schoenstein, R. (1995). Making block scheduling work. Education Digest, 60, 15-19.

Schoenstein, R. (1995). The new school on the block. Executive Educator, 17, 18-21.

Senge, Peter M., Kleiner, Art, Roberts, Charlotte, Ross, Richard, Roth, George, and

Smith, Brian. (1999). A fifth discipline resource: The dance of change. New York:

Currency/Doubleday.

Senge, Peter M. (1990). The fifth discipline. New York: Doubleday.

Sessoms, J. C. (1995). Teachers perceptions of three models of high school block scheduling. Unpublished doctoral dissertation. University of Virginia.

Shortt, T. L. \& Thayer, Y. V. (1999). Block scheduling can enhance school climate. Educational Leadership, 56(4), 76-81.

Shortt, Thomas L. \& Thayer, Y. V. (December 1998-January 1999). Block scheduling can enhance school climate. Educational Leadership, 56(4), 76- 81.

Shortt, T. L. \& Thayer, Y. V. (1995). What can we expect to see in the next generation of block scheduling? NASSP Bulletin, 79, 53-62.

Sizer, Theodore R. (September 1999). No two are quite alike. Educational Leadership, 57(1), 6-11.

Sizer, T. R. (1996). Horace's hope: What works for the American high school, NY, NY: Houghton Mifflin.

Sizer, T. R. (1990). Horace's school: Redesigning the American high school. 
Buston: Houghton Mifflin.

Skrobarcek, S. A. (1997). Collaboration for instructional improvement: Analyzing the academic impact of a block scheduling plan. NASSP Bulletin, 81, 104-111.

Snyder, Thomas D. (1996). "Trends in Education." Principal, 76.

Sparks, Dennis. (September, 1996). Results-driven staff development.

Education Week, 16:1, 16.

Strock, Gerald E. and Hottenstein, David S. (March, 1994). "The First-Year Experience: A High School Restructures Through Copernican Plan." The School Administrator, 51, 3, 30-31.

Sturgis, Jeffrey D. (Summer 1995). "Flexibility Enhances Student Achievement." NASSP AP Special: The Newsletter for Assistant Principals, 10, 4.

Tanner, B. M. (1996). Perceived staff needs of teachers in high schools with block schedules. Unpublished doctoral dissertation. University of Virginia, Charlottesville.

Tanner, B., Canady, R. L. and Rettig, M. D. (Fall, 1995). Scheduling Time to Maximize Staff Development Opportunities. Journal of Staff Development, 16 (4), 14-19.

Tewel, Kenneth J. (October, 1991). Promoting Change in Secondary Schools. NASSP Bulletin, 75(537), 10-17.

Trump, J. L. (1959). Images Of The Future: A New Approach To Secondary Schools. Washington, DC: NASSP.

Watts, Gary D. and Castle, Shari. (December, 1993). "The Time Dilemma in School Restructuring." Phi Delta Kappan, 75, 4, 306-310. 
Wayne, Sandra K. (1998). The implications of changing to a block schedule for learning disabled students. (Unpublished doctoral dissertation).

Wilson, C. (1995). The 4:4 block system: A workable alternative. NASSP Bulletin, 79, 63-65. 
APPENDICES 


\section{APPENDIX A \\ BLOCK SCHEDULING \\ STUDENT SURVEY}

Name:

1. Last year I attended Steubenville High School (circle one)

True False

2. This year I am in grade
A 09
B 10
C 11
D 12

3. With the new block schedule this year, I believe I am understanding my lessons better than last year.
A strongly agree
B agree
C disagree
D strongly disagree
E no difference between this year and last year

4. My grades for this nine weeks this year were generally ___ than in the past.
A better
B worse
C about the same

5. I am being assigned homework this year.
A more
B less
C about the same

6. I am experiencing confusion about homework assignments this year.
A more
B less
C approximately the same 
7. I am finding it to complete my homework assignments this year.
A easier
B harder
C about the same

8. I am alert and attentive in class this year.
A more
B less
C about the same as last year

9. I like learning better in ninety-minute blocks of time.
A strongly agree
B agree
C disagree
D strongly disagree
E length of class period makes no difference

10. The option of taking an eighth course on the four-four plan is for me.
A an advantage
B a disadvantage
C does not matter to me

11. I seem to be learning this year.
A more
B less
C about the same

12. How many of your teachers lecture too much?
A four
B three
C two
D one
E none

13. My teachers are providing variety in instructional activities than they did last year.
A more
B less
C about the same as last year 
14. Compare student behavior in the classroom under the two systems.
A This year there is less disruptive/inappropriate behavior.
B This year there is more disruptive/inappropriate behavior.
C Things are about the same as last year.

15. I find that the general behavior of students around the school (corridors, commons, class changes, etc.) is
A better than last year
B worse than last year
$\mathrm{C}$ about the same as last year

16. My teachers have been in more contact with my parents this year.
A strongly agree
B agree
C disagree
D strongly disagree
E no difference between this year and last year.

17. My teachers seem to know me better this year.
A strongly agree
B agree
C disagree
D strongly disagree
E no difference between this year and last year

18. I know my teachers better this year.
A strongly agree
B agree
C disagree
D strongly disagree
E no difference between this year and last year

19. My teachers seem to be helping me more this year.
A strongly agree
B agree
C disagree
D strongly disagree
E no difference between this year and last year 
20. Compare your feelings toward this year with your feelings last year.
A I like my teachers more this year.
B I like my teachers less this year.
C My feelings are about the same as last year.

21. In general, what has been your attitude toward school for the past two or three years?
A I liked it.
B I did not like it.
C My feelings were neutral.

22. Consider whether your feelings toward school have changed under the new system with the four-period day.
A I like school more now.
B I like school less now.
C I feel about the same as in past years.

23. I feel generally___ at managing school this year.
A more successful
B less successful
C about the same degree of success as in the past

24. I am experiencing___ stress related to school this year.
A more
B less
C about the same

25. Considering all your impressions about the four-period block schedule, select a response.
A I would like to remain on the four-period day.
B I would like to return to a seven-period day.
C Both programs are about the same, so it doesn't matter

26. Additional comments about anything related to the four-four plan 


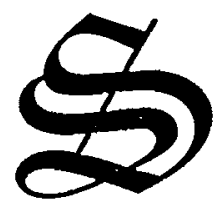

To Whom It May Concern,

I give my consent for Charles $T$. Keenan to distribute a survey questionnaire to students at Steubenville High School for the purpose of determining differences in student attitude with the change from a tracitional to a block schedule. I also give my permission to Charles T. Keenan to use school attendance and grade reports of students at Steubenville High School for use in his dissertation.

Sincerely,<smiles>CCC[Te]</smiles><smiles>CCCC</smiles>

Charles Joyce, Ed D

Superintendent, Steubenville City Schools 


\section{Protocol Review \\ West Virginia University Institutional Review Board PO Box 6845}

PO Box 6845

$1 / 28 / 00$

TO Charles Keenan

FROM Marian J. Turner

Executive Secretary to the Board

PROJECT TITLE H.S. 14468 Differences in Groupings

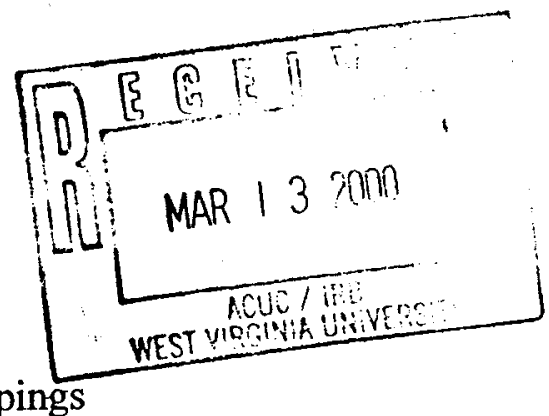

of Students' Academic Achievement, Attendance

and Attitude as they Move from Traditional to

Block Scheduling

Last Annual Review 05/21/99 Review Type Exp.

Date Last Consent Approved 05/21/99

The Institutional Review Board (IRB) grants approvals for the use of human subjects for a maximum of one year. Your renewal date is approaching. Check the appropriate box below and sign and return this form whether or not you are continuing the project.

Sign this page and return it with the attached progress report and required additional pages, as appropriate. Submit with this report a clean copy of all consent and assent forms, cover letters and ads along with the last-approved, stamped copy of each of these documents; they will be reviewed and, when approved, stamped and returned for your use with future subjects.

\section{Check One:}

A. Enrollment of subjects began on

(date) and will continue beyond the renewal date. (Submit a clean, unstamped copy—on letterhead-of all consent and assent forms, cover letters and ads; also submit a copy of last-approved, stamped forms, letters and ads.)

B. Project is closed to enrollment, but subjects are being followed.

C. Research began on (date). Contact with human subjects will not continue beyond the renewal date. Please close this file.

D. Funding or start of research is pending. Please keep this file active. (Remember to submit a clean, unstamped copy - on letterhead—of all consent and assent forms, cover letters and ads; also submit a copy of your last-approved, stamped consent and assent forms, cover letters and ads.)

E. Project was never begun. Please close this file.

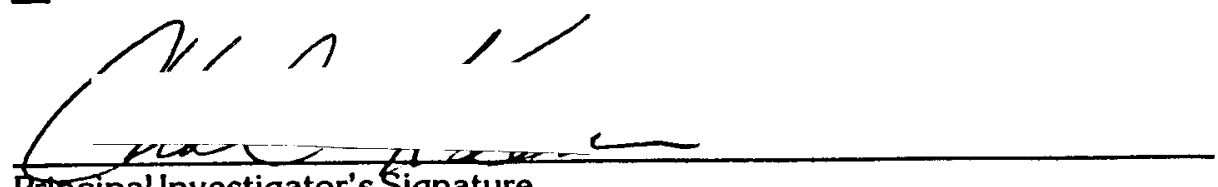

Prtncipal Investigator's Signature

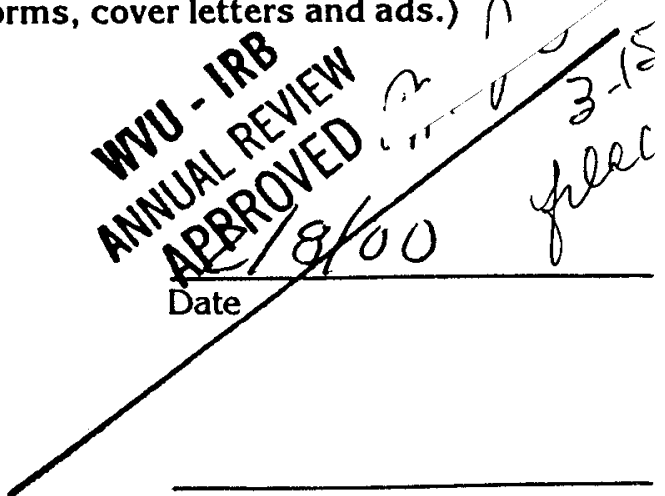

Date 


\title{
Institutional Review Board Progress Report
}

\author{
HS $\# 14468$
}

Instructions: Use a separate sheet if needed for any item. If any question is not applicable, put N/A next to the number for that question. All forms are available from the IRB staff and from the Web at

http://www.wvu.edu/ osp/forms.html

1. For each category below, indicate the number of subjects enrolled into the study last year at this institution.

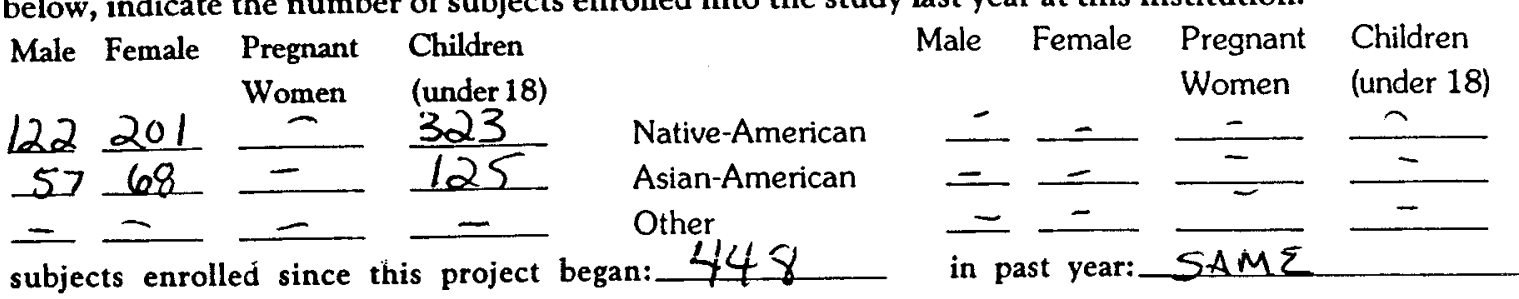

2. Have any subjects dropped out? If so, why? NO

3. Have all subjects signed a consent or assent form?

If no, were consent or assent waived for this project?

b. Have there been any problems obtaining informed consent or assent? Explain.

c. Are all signed forms on file and available for review?

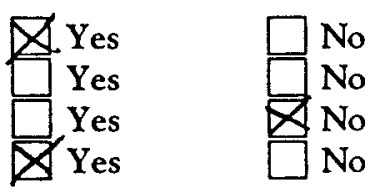

4. Have activities involving human subjects during the past year followed procedures as described in the approved protocol? $\square$ Yes $\square$ No If not, describe any modifications.

5. Adverse Events

Use the table on the reverse to list and summarize all adverse events at WVU and other sites. Provide a description and explanation of these events.

Note: An adverse event is one reportable to the sponsor or any event that occurs more frequently than anticipated.

For clinical, drug or device studies:

- If you are using an experimental drug or device for this protocol, what is its FDA status?

- Attach a copy of all new information, letters, or text of verbal updates that have been approved by the IRB. Additional updates not previously approved should be included at this time.

6. Summarize the preliminary results of this research. QUESTIONAAIRES RECEIVED, NOT YET REVIEWEI

7. List and explain any projected changes (for example, co-investigators, procedures, site of subject contact, or size, sex or age of population). Any new co-investigator(s) must sign and provide their qualifications (do not submit complete vitas). NONE

8. Attach a summary of recent literature that suggests anything new or important for continuing the project (e.g., new reactions, new treatments, changes in risk/benefit ratios, etc.). NON $\mathcal{E}$

9. Do you plan to enroll more subjects? $\square$ Yes $\quad$ No

10. a. If you wish to continue enrolling subjects, you must attach a clean, unstamped copy—on letterhead —of all consent and assent forms, cover letters and ads along with the last-approved, stamped copy of each of these documents $N / A$

b. If you plan to modify the consent or assent form, cover letter or ad, you must use the Amendment Form and provide the following: $N$ if

1) photocopy of current stamped forms, letters and ads

2) modified forms, letters or ads with changes indicated by brackets

3) clean copy of the modified forms, letters or ads (without brackets required in \#2 above) 


\section{DIFFERENCES IN GROUPINGS OF STUDENTS' ACADEMIC ACHIEVEMENT, ATTENDANCE AND ATTITUDE AS THEY MOVE FROM TRADITIONAL TO BLOCK SCHEDULING}

Introduction.

I, , have been asked to allow my child to participate in this study. Charles T. Keenan, who is conducting this research to fulfill the requirements for a doctoral dissertation in Educational Administration at West Virginia University, has explained the study to me.

Purposes of the Study. The purpose is to learn more about block scheduling and the differences that students encounter when changing from a traditional to a block schedule.

Description of Procedures. This study will be performed at Steubenville High School. My child will be asked to complete a questionnaire, which will take about 15 minutes to complete. I have been given an opportunity to examine this questionnaires. Approximately 500 subjects will be entered in this study.

Risks and Discomforts. There are no known or expected risks from participating in this study.

Benefits. I understand that this study is not expected to be of direct benefit to my child, but the knowledge gained may be of benefit to others.

Contact Persons. For more information about this research, I can contact Charles T. Keenan at 282-9741 or his supervisor, Dr. Charles Joyce, at 283-3767.

For information regarding my child's rights as a research subject, I may contact the Executive Secretary of the Institutional Review Board at 304-293-7073.

Confidentiality. I understand that any information obtained as a result of my child's participation in this research will be kept as confidential as legally possible. I understand that these research records, just like hospital records, may be subpoenaed by court order or may be inspected by federal regulatory authorities. My name or that of my child or any information from which we might be identified may not be published without my consent.

Voluntary Participation. Participation in this study is voluntary. I understand that I may withdraw my child from this study at any time. Refusal to participate or withdrawal will involve no penalty or loss of benefits for me or my child. My child's grades or class standing will not be affected. I have been given the opportunity to ask questions about the research, and I have received answers concerning areas I did not understand. Upon signing this form, I will receive a copy.

I willingly consent to my child's participation in this research.

Signature of Parent or Guardian

Date Time 


\section{ASSENT FORM}

\section{DIFFERENCES IN GROUPINGS OF STUDENTS' ACADEMIC ACHIEVEMENT, ATTENDANCE AND ATTITUDE AS THEY MOVE FROM TRADITIONAL TO BLOCK SCHEDULING}

Introduction. I, been explainedto me by Charles T. Keenan. have been asked to be in this research study, which has

Purposes of the Study. The purpose is to learn more about block scheduling and the differences that students encounter when changing from a traditional to a block schedule.

Description of Procedures. This study will be performed at Steubenville High School. -. I will be given several lists of written questions to answer. It will take me about 15 minutes to answer the questions. I do not have to answer all of the questions.

Discomforts. Some of the questions will be difficult and I may not enjoy trying to answer them.

Benefits. I understand that this study is not expected to help me, but what they learn from study may help other people.

Confidentiality. I have been promised that anything they learn about me in this study will be kept as secret as possible.

Voluntary Participation.

I have been told that I do not have to do this. No one will be mad at me if I refuse to do this or if I decide to quit. My grades or class standing will not be affected. I have been allowed to ask questions about the research, and all of my questions were answered.

I willingly agree to be in this research.

Signature of Subject 


\section{Appendix F}

Question 26: Additional comments about anything related to the four-four plan.

\section{$\underline{\text { Comments }}$}

In many cases, the responses were repetition, but the largest number of responses indicated that the students enjoyed their block schedule classes. The following are the varied comments made by students.

"Teachers teach the same way as before."

"I like the fact that we can do more activities."

"There is less homework."

"It gets boring."

"Teachers get to know us better."

"If the teachers are good, it's fine, but if they only lecture, it's too long."

"Some teachers lecture too much."

"I like it."

"Having fewer classes gives me a chance to get my homework done."

"Some students don't pay attention, but I think it's better than before."

"We get more attention from the teacher."

"It's tough to make up work if you're absent." 
Appendix $G$

Questions Three Through Twenty-Five

Individual Quartile, Total and Aggregate Percentage of Responses

Question 3. With the new block schedule this year, I believe I am understanding my lessons.

\begin{tabular}{|l|l|c|c|c|c|c|}
\hline & & TOTAL & Q1 & Q2 & Q3 & Q4 \\
\hline A & Strongly Agree & $33 \%$ & & $21 \%$ & $(14 \%$ Average & of Q1,Q2,Q3) \\
\hline B & Agree & $55 \%$ & & & & \\
\hline C & Disagree & $23 \%$ & & & & \\
\hline D & Strongly Disagree & & & & & \\
\hline E & $\begin{array}{l}\text { No Difference Bet. } \\
\text { this year \& last year }\end{array}$ & $23 \%$ & & & & \\
\hline
\end{tabular}

Question 4. My grades for this nine weeks this year were generally than in the past.

\begin{tabular}{|l|l|c|c|c|c|c|}
\hline & & TOTAL & Q1 & Q2 & Q3 & Q4 \\
\hline A & Better & $39 \%$ & $19 \%$ & $54 \%$ & $50 \%$ & $37 \%$ \\
\hline B & Worse & $11 \%$ & & & & \\
\hline C & About the same & $50 \%$ & $72 \%$ & $(41 \%$ & Average of & Q2, Q3, Q4) \\
\hline
\end{tabular}

Question 5. I am being assigned homework this year.

\begin{tabular}{|l|l|c|c|c|c|c|}
\hline & & TOTAL & Q1 & Q2 & Q3 & Q4 \\
\hline A & More & $23 \%$ & & & & \\
\hline B & Less & $51 \%$ & & & & \\
\hline
\end{tabular}

Question 6. I am experiencing confusion about homework assignments this year.

\begin{tabular}{|l|l|c|c|c|c|c|}
\hline & & TOTAL & Q1 & Q2 & Q3 & Q4 \\
\hline A & More & $16 \%$ & $(12 \%$ & Average of & Q1, Q2, Q3) & $35 \%$ \\
\hline B & Less & $46 \%$ & & & & \\
\hline C & Approx. the same & $38 \%$ & $48 \%$ & (34\% Average & of Q2, Q3 & Q4) \\
\hline
\end{tabular}

Question 7. I am finding it to complete my homework assignments this year.

\begin{tabular}{|l|l|c|c|c|c|c|}
\hline & & TOTAL & Q1 & Q2 & Q3 & Q4 \\
\hline A & Easier & $40 \%$ & $29 \%$ & $48 \%$ & $43 \%$ & $37 \%$ \\
\hline B & Harder & $10 \%$ & & & & \\
\hline C & Approx. the same & $50 \%$ & $62 \%$ & (44\% Average & of Q2, Q3 & Q4) \\
\hline
\end{tabular}

Question 8. I am alert and attentive in class this year. 


\begin{tabular}{|l|l|c|l|l|l|c|}
\hline & & $\begin{array}{c}\text { TOTA } \\
\mathrm{L}\end{array}$ & Q1 & Q2 & Q3 & Q4 \\
\hline A & More & $25 \%$ & & & & \\
\hline B & Less & $43 \%$ & & & & \\
\hline C & About same as last year & $32 \%$ & & & & \\
\hline
\end{tabular}


Question 9. I like learning better in ninety-minute blocks of time.

\begin{tabular}{|l|l|c|c|c|c|c|}
\hline & & $\begin{array}{c}\text { TOTA } \\
\mathrm{L}\end{array}$ & Q1 & Q2 & Q3 & Q4 \\
\hline A & Strongly Agree & $25 \%$ & & & & \\
\hline B & Agree & $50 \%$ & $46 \%$ & $58 \%$ & $58 \%$ & $34 \%$ \\
\hline D & Sisagree & $25 \%$ & & & & \\
\hline E & $\begin{array}{l}\text { Strongly Disagree } \\
\text { Lofh Difsers Pd. Makes }\end{array}$ & & $31 \%$ & $(22 \%$ & Average of & Q2, Q3, Q4) \\
\hline
\end{tabular}

Question 10. The option of taking an eighth course on the four-four plan is for me.

\begin{tabular}{|l|l|c|c|c|c|c|}
\hline & & $\begin{array}{c}\text { TOTA } \\
\text { L }\end{array}$ & Q1 & Q2 & Q3 & Q4 \\
\hline A & An Advantage & $66 \%$ & & The Higher & the Quartile & Advantage \\
\hline B & A Disadvantage & $8 \%$ & $46 \%$ & The Lower & the Quartile & Disadvantage \\
\hline C & Does Not Matter To Me & $25 \%$ & & & & \\
\hline
\end{tabular}

Question 11. I seem to be learning this year.

\begin{tabular}{|l|l|c|c|c|c|c|}
\hline & & $\begin{array}{c}\text { TOTA } \\
\text { L }\end{array}$ & Q1 & Q2 & Q3 & Q4 \\
\hline A & More & $50 \%$ & $44 \%$ & $61 \%$ & $53 \%$ & $38 \%$ \\
\hline B & Less & $15 \%$ & & & & \\
\hline C & About the Same & $35 \%$ & $45 \%$ & $(31 \%$ & Average of & Q2, Q3, Q4) \\
\hline
\end{tabular}

Question 12. How many of your teachers lecture too much?

\begin{tabular}{|c|c|c|c|c|c|c|}
\hline & & $\begin{array}{c}\text { TOTA } \\
\text { L }\end{array}$ & Q1 & Q2 & Q3 & Q4 \\
\hline A & Four & & & & & $45 \%$ \\
\hline$B$ & Three & $35 \%$ & & & & \\
\hline $\mathrm{C}$ & Two & $29 \%$ & & & & \\
\hline $\mathrm{D}$ & One & $37 \%$ & $35 \%$ & & & \\
\hline$E$ & None & $14 \%$ & & & & \\
\hline
\end{tabular}

Question 13. My teachers are providing they did variety in instructional activities than last year.

\begin{tabular}{|l|l|l|l|l|l|l|}
\hline & & $\begin{array}{l}\text { TOTA } \\
\text { L }\end{array}$ & Q1 & Q2 & Q3 & Q4 \\
\hline A & More & $44 \%$ & & & & \\
\hline B & Less & $19 \%$ & & & & \\
\hline
\end{tabular}


Question 14. Compare student behavior in the classroom under the two systems.

\begin{tabular}{|l|l|c|c|c|c|c|}
\hline & & $\begin{array}{c}\text { TOTA } \\
\text { L }\end{array}$ & Q1 & Q2 & Q3 & Q4 \\
\hline A & $\begin{array}{l}\text { This yr. less } \\
\text { disrup.linapp.behavior }\end{array}$ & $18 \%$ & & & & \\
\hline B & $\begin{array}{l}\text { This yr. more } \\
\text { disruptive/inapp. behav. }\end{array}$ & $29 \%$ & & & & \\
\hline C & $\begin{array}{l}\text { hings About Same as } \\
\text { Last Yr }\end{array}$ & $52 \%$ & & & & \\
\hline
\end{tabular}

Question 15. I find that the general behavior of students around the school (corridors, commons, class changes, etc.) is

\begin{tabular}{|l|l|c|c|c|c|c|}
\hline & & $\begin{array}{c}\text { TOTA } \\
\text { L }\end{array}$ & Q1 & Q2 & Q3 & Q4 \\
\hline A & Better than last year & $24 \%$ & $21 \%$ & $28 \%$ & $28 \%$ & $18 \%$ \\
\hline B & Worse than last year & $16 \%$ & & & & $29 \%$ \\
\hline C & About same as last year & $60 \%$ & & & & \\
\hline
\end{tabular}

Question 16. My teachers have been in more contact with my parents this year.

\begin{tabular}{|l|l|c|c|c|c|c|}
\hline & & $\begin{array}{c}\text { TOTA } \\
\text { L }\end{array}$ & Q1 & Q2 & Q3 & Q4 \\
\hline A & Strongly agree & $24 \%$ & & & & \\
\hline B & Agree & $12 \%$ & & & & \\
\hline D & Disagree & $47 \%$ & & & & \\
\hline E & $\begin{array}{l}\text { Nongly Differ. Detweee } \\
\text { and Last Year }\end{array}$ & $42 \%$ & & & & \\
\hline
\end{tabular}

Question 17. My teachers seem to know me better this year.

\begin{tabular}{|l|l|c|c|c|c|c|}
\hline & & $\begin{array}{c}\text { TOTA } \\
\text { L }\end{array}$ & Q1 & Q2 & Q3 & Q4 \\
\hline A & Strongly agree & $27 \%$ & & & & \\
\hline B & Agree & $56 \%$ & $54 \%$ & $60 \%$ & $65 \%$ & $43 \%$ \\
\hline D & Disagree & $22 \%$ & $23 \%$ & $17 \%$ & $17 \%$ & $38 \%$ \\
\hline E & $\begin{array}{l}\text { Nongly Differ. Detwree } \\
\text { and Last Year }\end{array}$ & $21 \%$ & & & & \\
\hline
\end{tabular}

Question 18. I know my teachers better this year.

\begin{tabular}{|l|l|c|c|c|c|c|}
\hline & & $\begin{array}{c}\text { TOTA } \\
\text { L }\end{array}$ & Q1 & Q2 & Q3 & Q4 \\
\hline A & Strongly agree & $22 \%$ & & & & \\
\hline B & Agree & $62 \%$ & $58 \%$ & $66 \%$ & $68 \%$ & $50 \%$ \\
\hline C & Disagree & $18 \%$ & & & & \\
\hline D & Strongly Disagree & & & & & \\
\hline E & $\begin{array}{l}\text { No Differ.Between This Yr. } \\
\text { and Last Year }\end{array}$ & $20 \%$ & & & & \\
\hline
\end{tabular}


Question 19. My teachers seem to be helping me more this year.

\begin{tabular}{|l|l|c|c|c|c|c|}
\hline & & $\begin{array}{c}\text { TOTA } \\
\text { L }\end{array}$ & Q1 & Q2 & Q3 & Q4 \\
\hline A & Strongly agree & & & & & \\
\hline B & Agree & $20 \%$ & & & & \\
\hline D & Sisagree & $53 \%$ & & $14 \%$ & (23\% Average & Q1, Q2, Q4) \\
\hline E & $\begin{array}{l}\text { No Differ.Betwee } \\
\text { and Last Year }\end{array}$ & $18 \%$ & & & (Q1, Q3 and & Q4 $)$ \\
\hline
\end{tabular}

Question 20. Compare your feelings toward this year with your feelings last year.

\begin{tabular}{|l|l|c|c|c|c|c|}
\hline & & $\begin{array}{c}\text { TOTA } \\
\text { L }\end{array}$ & Q1 & Q2 & Q3 & Q4 \\
\hline A & Like my tchrs. more this yr & $26 \%$ & & (Aver. 28\% & Q1, Q2 & Q3, Q4) \\
\hline B & Like my tchrs. less this yr. & $19 \%$ & (Aver. Q1 & Q2 and & Q3) & $27 \%$ \\
\hline C & $\begin{array}{l}\text { Feelings About Same as } \\
\text { Last year }\end{array}$ & $64 \%$ & & & & \\
\hline
\end{tabular}

Question 21. In general, what has been your attitude toward school for the past two or three

$$
\text { years? }
$$

\begin{tabular}{|l|l|c|c|c|c|c|}
\hline & & $\begin{array}{c}\text { TOTA } \\
\text { L }\end{array}$ & Q1 & Q2 & Q3 & Q4 \\
\hline A & I liked it & $28 \%$ & +21 & +12 & +14 & \\
\hline B & I did not like it & $19 \%$ & & & & \\
\hline P & My feelings were neutral & $53 \%$ & & & & \\
\hline
\end{tabular}

Question 22. Consider whether your feelings toward school have changed under the new system with the four-period day.

\begin{tabular}{|l|l|c|c|c|c|c|}
\hline & & $\begin{array}{c}\text { TOTA } \\
\mathrm{L}\end{array}$ & Q1 & Q2 & Q3 & Q4 \\
\hline A & I like school more now & $29 \%$ & $26 \%$ & $38 \%$ & $33 \%$ & $14 \%$ \\
\hline B & I like school less now & $19 \%$ & & & & \\
\hline I feel about same as in \\
past years
\end{tabular}

Question 23. I feel generally at managing school this year.

\begin{tabular}{|l|l|c|c|c|c|c|}
\hline & & $\begin{array}{c}\text { TOTA } \\
\text { L }\end{array}$ & Q1 & Q2 & Q3 & Q4 \\
\hline A & More successful & $42 \%$ & $($ Over 40\% & Average Q1 & Q2, Q3) & $32 \%$ \\
\hline B & Less successful & $14 \%$ & & & & \\
\hline C & $\begin{array}{l}\text { About same degree of } \\
\text { success as in the past }\end{array}$ & $44 \%$ & & & & \\
\hline
\end{tabular}


Question 24. I am experiencing stress related to school this year.

\begin{tabular}{|l|l|c|c|c|c|c|}
\hline & & $\begin{array}{c}\text { TOTA } \\
\text { L }\end{array}$ & Q1 & Q2 & Q3 & Q4 \\
\hline A & More & $30 \%$ & & & & \\
\hline C & Less & $34 \%$ & & & & \\
\hline
\end{tabular}

Question 25. Considering all your impressions about the four-period block schedule, select a response.

\begin{tabular}{|l|l|c|c|c|c|c|}
\hline & & $\begin{array}{c}\text { TOTA } \\
\text { L }\end{array}$ & Q1 & Q2 & Q3 & Q4 \\
\hline A & $\begin{array}{l}\text { Would like to remain on } \\
\text { four period day }\end{array}$ & $49 \%$ & $37 \%$ & $67 \%$ & $53 \%$ & $35 \%$ \\
\hline B & $\begin{array}{l}\text { Would like to return to } \\
\text { seven-period day }\end{array}$ & $23 \%$ & & & & \\
\hline C & $\begin{array}{l}\text { Both programs about the } \\
\text { same, doesn't matter }\end{array}$ & $28 \%$ & $42 \%$ & & & \\
\hline
\end{tabular}

